\title{
VYBRANÉ DOKLADY REMESELNEJ ČINNOSTI NA OPEVNENOM SÍDLISKU II V NIŽNEJ MYŠLI ${ }^{1}$
}

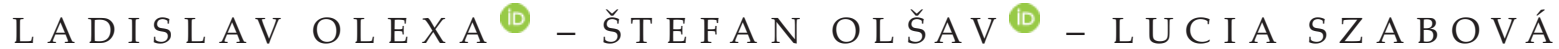

\begin{abstract}
Selected Evidence of Crafts at the Fortified Settlement II in Nižná Myšla. Nižná Myšla is well known to the expert as well as general public, as an archaeological site, mainly in association with a burial ground and fortified settlement from the Early and Middle Bronze Age. Fortified settlements are one of the specific features of the northern enclave of the Otomani-Füzesabony cultural complex and they represented production, trade, religious and later also power centres. The article deals with the fortified settlement II from the beginning of the Middle Bronze Age. The archaeological excavation in Nižná Myšl’a has been conducted since 1977. Based on the current knowledge, we can state that intense craft activities took place at fortified settlement II. With regard to the extent of craft activities, the article focuses on activities associated with metallurgy and lithic industry. These two topics are partly interconnected, since evidence of metallurgy contains mainly lithic casting moulds. Final finish of metal objects is associated with various tools for grinding, smoothing and polishing which are frequent at the site. Metallurgy was the moving power of the economy in the Bronze Age and Nižná Myšla was one of its centres. Lithic industry, on the other hand, played an important role in people's everyday life and was used in almost all types of industry. Therefore, its location in the area of fortified settlement II offers us an opportunity to partly locate craft districts and reconstruct the economic-production model of the settlement itself.
\end{abstract}

Keywords: Eastern Slovakia, Early Bronze Age, Middle Bronze Age, Otomani-Füzesabony cultural complex, fortified settlement, craft activities, metallurgy, lithic industry.

\section{ÚVOD}

Opevnené sídliská otomansko-füzesabonyského kultúrneho komplexu (d’alej len OFKK) sú v literatúre okrem iného charakterizované ako hospodárske a výrobné centrá (napr. Gašaj 2002, 21 nn.). Často sa však doklady výrobnej činnosti obmedzovali len na opis konkrétnych typov nálezov a ojedinelých objektov s výrobným charakterom. Výnimkou je oblast' metalurgie, ktorá sa teší oblube mnohých odborníkov. V posledných rokoch sa však pozornost' bádatelov upriamuje aj na vztahy človeka k svojmu širšiemu, aj užšiemu životnému priestoru. Práve tento pohlad a spôsob bádania umožňuje koncipovat' rôzne hospodársko-ekonomické modely, ktoré nám pomáhajú pochopit špecifické fenomény, deje a procesy zachytené desatročiami archeologických výskumov. Aktuálny stav bádania OFKK nám dnes dovoluje takéto modely vytvárat', aj ked’ je táto téma stále vo svojich začiatkoch. V príspevku sa venujeme dokladom výrobných činností a ich umiestneniu $\mathrm{v}$ doposial preskúmanom priestore (cca jedna tretina z predpokladanej rozlohy) opevneného sídliska II v Nižnej Myšli (plán 1) so zameraním na metalurgiu a kamennú industriu.

\section{DOKLADY METALURGIE NA OPEVNENOM SÍDLISKU II}

Opevnené sídliská OFKK boli okrem iného významnými metalurgickými centrami s výnimočne početnými dokladmi produkcie farebných kovov (Bátora 2009, 219; Găvan 2015; Jaeger 2016, 119-127). Metalurgická činnosṫ zohrávala významnú úlohu aj na opevnenom sídlisku II v Nižnej Myšli. Počas systematického archeologického výskumu tu boli objavené odlievacie formy, hlinené tégliky, dávkovacie lyžice, dýzy a kovové artefakty, ktoré reprezentujú rozličné finálne výrobky, polotovary, ale aj nepodarky. Kovové predmety boli pravdepodobne vyrábané pre vlastnú potrebu, a taktiež za účelom výmenného obchodu. Šperky zastupovali artefakty ako napríklad náramky, záušnice, prívesky, ihlice, prstene, koráliky, špirálky a nášivky. Obyvatelom slúžili ako pracovné nástroje sekery, ihly, rydlá/šidlá, dlátka, nože, kosáky, unikátom je fragment pílky. Predmety identifikované ako zbrane sú doložené nálezmi dýk, oštepov/ kopijí, sekeromlatov a hrotov šípov (Olexa 2003, 59). V rámci metalurgie sa zvlášt vyníma zahíbený objekt 519, v ktorom bola objavená doposial' najväčšia koncentrácia kovových predmetov (šperky, súčasti

\footnotetext{
1 Táto práca bola podporená Agentúrou na podporu výskumu a vývoja na základe Zmluvy č. APVV-18-0276 („Prostredie a sídliskové siete mladšieho praveku na príklade vybratých období a regiónov Slovenska“), ako aj Vedeckou grantovou agentúrou VEGA pod číslom projektu 2/0084/18 („Vývoj a premeny sídliskových štruktúr horného Potisia v praveku a v rannej dobe dejinnej“).
} 


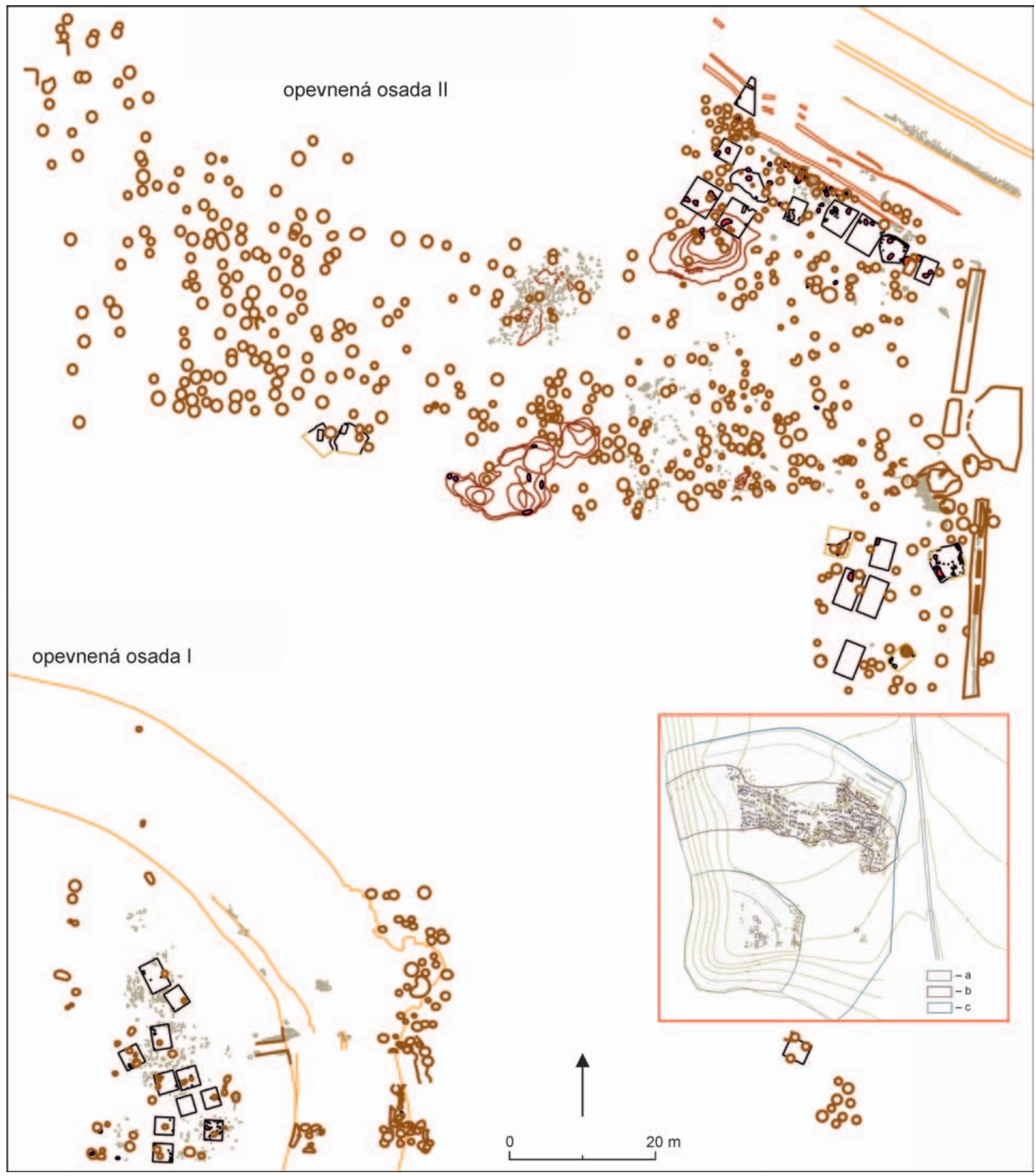

Plán 1. Nižná Myšla-Várhegy. Preskúmané plochy opevnených sídlisk I a II a schematický plán náleziska (Nováček 2017, mapa 2). Legenda: a - opevnené sídlisko I; b - pohrebisko prislúchajúce opevnenému sídlisku I; c - opevnené sídlisko II.

odevu, pracovné nástroje, polotovary) a kamenných artefaktov (nástroje na brúsenie, hladenie, leštenie, štiepaná industria, kamenné kadluby; Olšav 2019; Szabová 2017). Objekt datujeme do poklasického stupňa OFKK z počiatku strednej doby bronzovej (Szabová 2017). Vykonávanie prvotnej kovolejárskej činnosti si vyžadovalo miesto v bezpečnej vzdialenosti od obydlí, čomu nasvedčuje umiestnenie objektu do okrajovej časti opevneného sídliska II (Olexa 2003, 47). Nepravidelnost' pôdorysu objektu a nerovné dno možno porovnat's metalurgickou dielňou objavenou na lokalite Lovasberény-Mihályvár (Petres/Bándi 1969). Iný typ metalurgickej dielne, objavenej v deštrukcii domu, sa nachádzal na lokalite Mošorin-Feudvar, prislúchajúcej vatínskej kultúre (Fischl/Kiss/Kulcsár 2013, 13 n.). A. Găvan (2015, 472 n.) predpokladala, že 


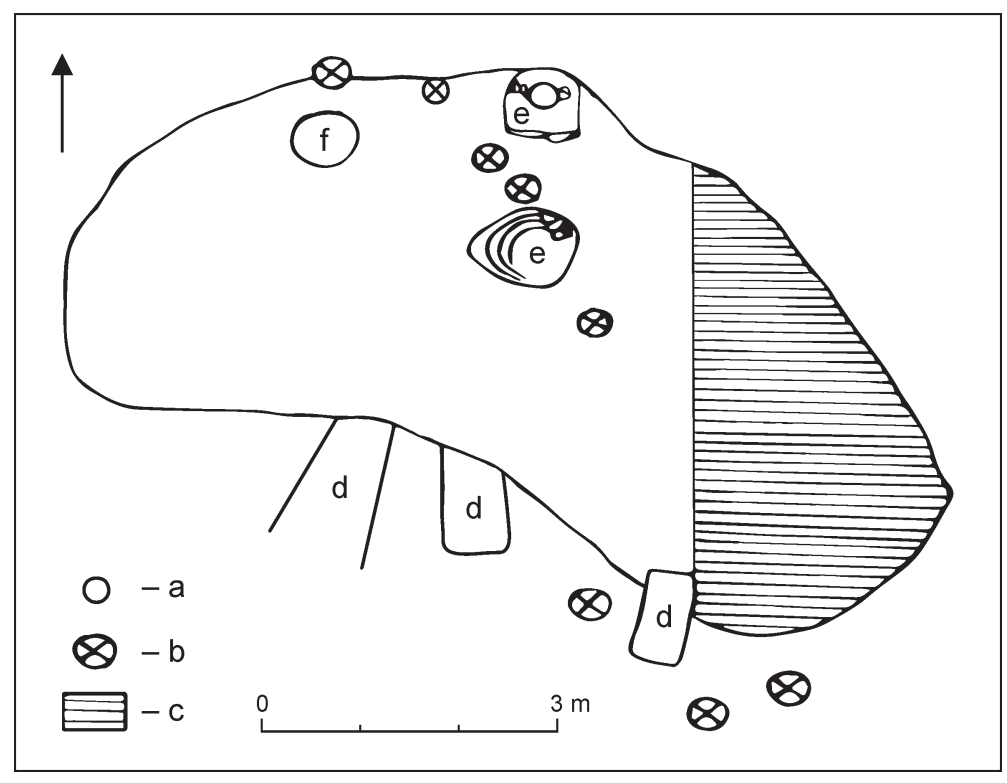

Obr. 1. Nižná Myšla-Várhegy. Objekt 519 - metalurgická dielňa. Legenda: a - jama s popolovitou výplňou; b - kolová jama; c - nepreskúmaná plocha; d - hrob; e - pyrotechnologické zariadenie; f-jama (upravené podla Szabová 2017, obr. 1).

aktivity súvisiace s metalurgiou v Karpatskej kotline mohli prebiehat práve $\mathrm{v}$ podobných domoch, a nie v samostatných výrobných areáloch. Trefne však pripomenula, že tento pohl'ad môže byt' ovplyvnený stavom bádania, resp. nedostatočným výskumom špecifických území. Tento pohlad môžu zmenit práve objavy v Nižnej Myšli. Početné nálezy fragmentov a kompletne zachovaných artefaktov z objektu 519 súvisiacich $\mathrm{s}$ kovolejárskou činnostou $\mathrm{v}$ priestore $4,5 \times 6 \mathrm{~m}$ napovedá skôr o ich používaní priamo $\mathrm{v}$ tomto objekte. Líšia sa od zahodených predmetov, ktoré sa často objavujú v zásypoch odpadových jám. Odlievacie formy a tégliky so zvyškami kovu na povrchu boli taktiež využívané priamo v objekte 519 čoho dôkazom je ich koncentrácia v popolovitej vrstve v blízkosti deštruovanej vyhne na dne výrobného objektu. Výrazne prepálené vrstvy nachádzajúce sa medzi estrichmi spomínaného pyrotechnologického zariadenia interpretáciu podporujú. Kovové výrobky boli väčšinou zastúpené $\mathrm{v}$ zlomkoch, pričom prevažovali najmä ozdoby odevu. V objekte 519 sa nachádzali kovové predmety $\mathrm{v}$ podobe šperkov, súčastí odevov, pracovných nástrojov a polotovarov (Szabová 2017, 34). Druhá atypická pec objavená vo vyššej vrstve by mohla znamenat istý presun výrobného objektu smerom na sever, ako je tomu v Rakúsku na lokalite Styria, kde bola preskúmaná dielňa slúžiaca na tavenie medi (Kraus a i. 2015, 301). Spolu s objektom 519 sa v severovýchodnej časti opevneného sídliska nachádzalo množstvo prepálených vrstiev a deštrukcií pecí, ktorých charakter sa z celkového kontextu javí ako výrobný, a teda mohol okrem iného súvisiet aj s metalurgickou činnostou.

\section{Metalurgický objekt 519}

Objekt 519 sa nachádza v severnej časti opevneného sídliska II v sonde 55 a 56 (obr. 1). Pôdorys objektu mal nepravidelný obličkovitý tvar. $\mathrm{V}$ roku 2013 sa pristúpilo $\mathrm{k}$ jeho preskúmaniu, pričom sa podarilo zachytit výnimočné nálezové situácie. Dno sondy 55 bolo morfologicky členité, nerovné, s maximálnou híbkou $2 \mathrm{~m}$. Na dne boli odkryté dve jamy (kolové?), ktoré boli od seba vzdialené $22 \mathrm{~cm}$. Na dne objektu bola objavená deštrukcia pyrotechnologického zariadenia, pravdepodobne pece. Unikátnost' spočíva v jej opätovnom obnovovaní. Svedčia o tom až štyri estrichy nachádzajúce sa nad sebou, pričom medzi jednotlivými estrichmi sa nachádzali silno prepálené vrstvy hliny (obr. 2: 1). Po použití boli steny pece odstránené a na pôvodný estrich sa naniesla vrstva hliny, na ktorej sa vystavala d’alšia pec, pričom na jej dne vznikol vplyvom vysokej teploty další estrich. Dočervena prepálené vrstvy medzi estrichmi poukazujú na vysokú teplotu dosiahnutú v peciach. Šírka dočervena prepálených vrstiev s estrichmi bola približne $100 \mathrm{~cm}$ a výška $40 \mathrm{~cm}$. Na najvyššom estrichu boli uložené tri kamene. Pred pyrotechnologickým zariadením sa podarilo zdokumentovat predpecnú jamu, ktorá obsahovala popolovitú výplň (Szabová 2017, tab. XI). Ďalšia pec bola objavená vo vyššej vrstve. Nachádzala sa iba $1 \mathrm{~m}$ smerom na sever od opakovane vystavanej pece (obr. 2: 2), pričom objavené kolové jamy mohli súvisiet' s prestrešením objektu (obr. 2). Budovanie mladších pecí smerom na sever od starších je doložené napríklad už na spomenutej lokalite Styria, kde 

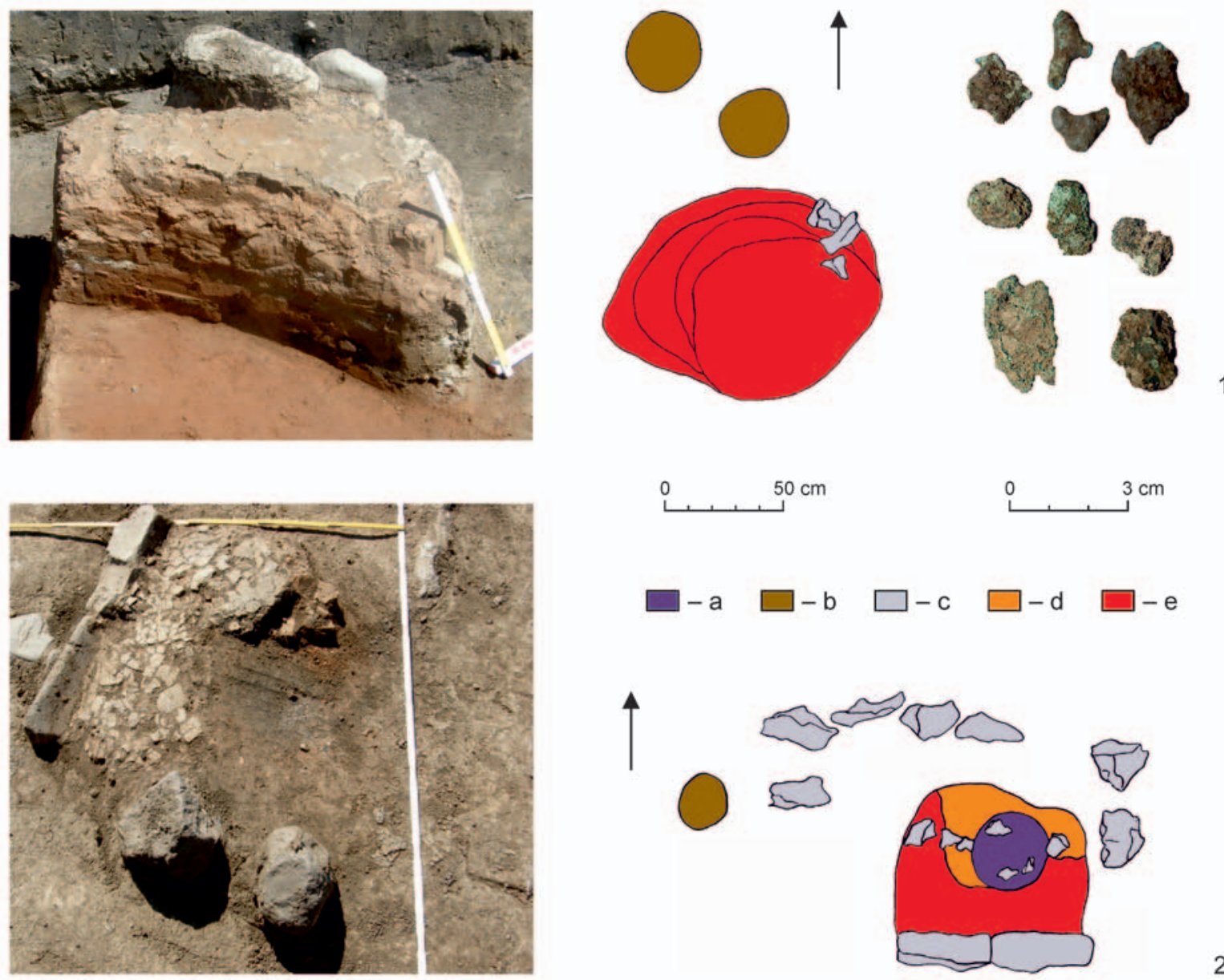

Obr. 2. Nižná Myšl'a-Várhegy. Pyrotechnologické zariadenia z objektu 519. 1 - viacnásobne obnovená pec so štyrmi nad sebou sa nachádzajúcimi estrichmi, ktoré od seba oddelujú vrstvy prepálenej hliny a zliatky bronzu; 2 - deštrukcia pece, ktorú ohraničovali masívne kamene. Legenda: a - jama s popolovitou výplňou; b - kolová jama; c - kameň; d prepálená vrstva; e - estrich.

sa nachádzala dielňa na tavenie medi (Kraus a i. 2015, 301). Do úvahy teda prichádza možnost presunutia metalurgickej činnosti bližšie k opevneniu smerom na sever. Najbližšiu analógiu z územia Slovenska predstavuje výrobný kovolejársky objekt z Radzoviec (Furmánek 2010). Objekt mal približne rovnaké rozmery ako objekt 519 z Nižnej Myšle. Spodné vrstvy objektu z Radzoviec boli čiernej farby, podobne ako v prípade objektu 519, kde malo dno výrazne popolovitý charakter. $V$ rámci okrajovej južnej časti boli odkryté dva hroby (hrob 789 a 792) patriace do staršieho pohrebiska. Oba hroby sa nachádzali v subpozícii vzhladom na objekt 519, pričom boli zásahom vzniknutého objektu značne porušené.

Výskum objektu pokračoval s dvojročnou prestávkou v roku 2016, kedy bola skúmaná plocha odkrytá d’alej smerom na východ. $V$ poslednej etape sa podarilo zachytit $v$ podstate už len južný a vý- chodný okraj objektu, pričom v južnej časti sondy 56 bol objavený zničený hrob 797, opät v subpozícii s objektom 519. Zahĺbená čast̉ kovolejárskej dielne mala rozmery približne $4,5 \times 6 \mathrm{~m}$.

Charakter objektu spolu s početnými nálezmi odlievacích foriem, téglikov, bronzovej suroviny a nepodarkov dokazuje jeho primárne využitie v oblasti metalurgie. Nálezy z objektu sú prezentované na nasledujúcich stránkach príspevku. Po skončení primárnej funkcie objektu (snád’ kvôli zvýšeniu terénu následkom hromadenia popola?) sa objekt sekundárne využil ako odpadová jama. Zaujímavý je vysoký počet nálezov štiepanej industrie, ktoré najskôr súvisia s intenzívnejšou produkciou $\mathrm{v}$ domoch $\mathrm{v}$ blízkosti objektu. Téme štiepanej industrie je venovaná samostatná kapitola príspevku. V objekte 519 sa zdokumentovala taktiež vysoká koncentrácia fragmentov keramic- 


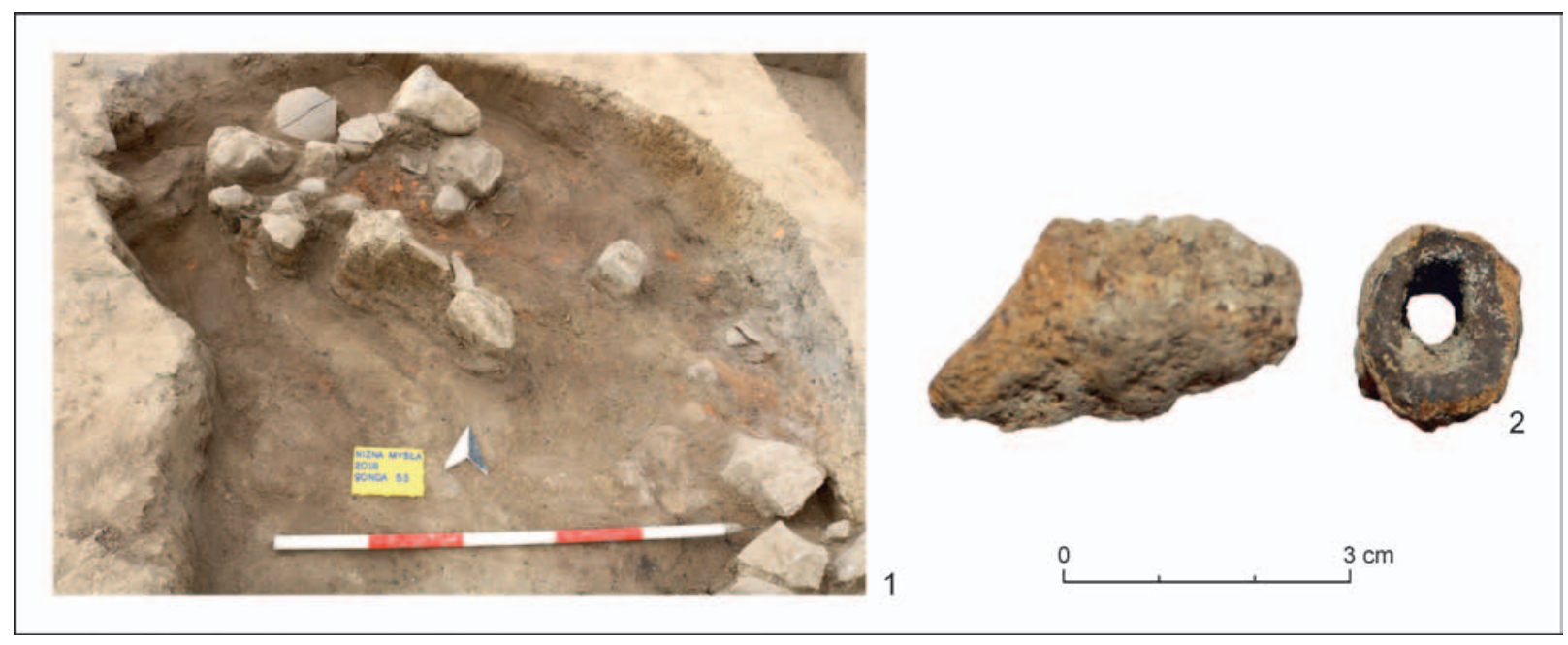

Obr. 3. Nižná Myšla-Várhegy. 1 - ohnisko ohraničené kameňmi; 2 - hlinená dýza objavená v bezprostrednej blízkosti ohniska.

kých nádob a zvieracích kostí. Množstvo keramiky umožňuje datovat záver fungovania predpokladanej metalurgickej dielne do Reineckeho stupňa BB1 (Szabová 2017, 41). Nálezy zo starších stupňov súvisia najskôr s narušením niektorých hrobov pohrebiska samotným objektom.

\section{Výber pyrotechnologických zariadení zo severovýchodnej časti opevneného sídliska II}

\section{Pyrotechnologické zariadenie nad objektom 567}

V severnej časti sondy 53 sa nachádzal zhluk kameňov a väčších črepov, ktoré tvorili ohnisko. Deštrukcia ohniska sa nachádzala nad objektom 567 (obr. 3: 1). Spodná čast’ ohniska predstavovala súvislú dočervena prepálenú vrstvu, pod ktorou sa nachádzala biela sypká vrstva. Stratigrafické vrstvy v priestore ohniska a ich štruktúra sú analogické so situáciou pozorovanou $\mathrm{v}$ ohniskách počas experimentálnych výpalov (Bentsen 2014, 156, 158 n.). Pri ohnisku sa nachádzalo 12 mušlí a keramická dýza (obr. 3: 2). Hlinené dýzy tvorili ukončenia kožených mechov slúžiacich na rozdúchavanie ohňa, pričom sú všeobecne považované za dôkaz vysokej technologickej úrovni metalurgov (Bátora 2018, 345). Výplň objektu 567 pozostávala z množstva fragmentárnych kusov mazanice. Fragmenty boli zväčša silno prepálené a hladené badatelnou tenkou vrstvou bielej farby na povrchu (vápno?). V súbore mazanice z objektu 567 sa nachádzajú aj zlomky s otlačkami prútov, či plasticky zdobenými fragmentmi v tvare klenby (obr. 4: A: 2, 3, 5, 6;
Szabová 2019, 52, tab. XV). Plastické zdobenie bolo vytvorené prstom, čo dokladajú negatívy pretláčaných podlhovastých priehlbín. Predpokladá sa, že výskyt plasticky zdobenej mazanice možno spojit’ s vplyvom egejskej oblasti v období staršej doby bronzovej (Ilon 2014, 34). Objavených 54 exemplárov tohto druhu však tvarovo súvisí s prostredím doby bronzovej v Karpatskej kotline. Najčastejšie sa plasticky zdobená mazanica objavuje na území Slovenska, Českej republiky, Mad’arska a Srbska (KmetoválHladíková/Gregor 2010, 151), pričom sa vyskytuje prakticky počas trvania celej doby bronzovej. Na analyzovaný súbor však nachádzame analógie aj priamo v strednej dobe bronzovej (Ilon 2014, obr. 6). Zdobenie v tvare oblúka (obr. 4: A: 2, $3,5,6)$ mohlo byt’ pôvodne súčastou cípovitého útvaru zdobiaceho nadzemnú konštrukciu domu, ako je tomu v Nižnej Šebastovovej (poloha Griblovec), ktorá je datovaná do OFKK, resp. do stupňa BB1. Podobne ako v prípade nálezov zo strednej doby bronzovej z Levíc-Géne, či Trebatíc (Kmetovál Hladíková/Gregor 2010, 148, 152; Paulík 1962, obr. 10; Šimčík 2017, 92). Ďalšou možnou interpretáciou je, že pôvodne plasticky zdobená mazanica predstavovala zdobenú hlinenú obrubu lemujúcu ohnisko, rovnako ako $\mathrm{v}$ prípade nálezu $\mathrm{z}$ opevneného sídliska OFKK v Košiciach-Barci (Paulík 1962, 28). Fragment s výčnelkom pochádza z objektu 567 (obr. 4: A: 1). $\mathrm{K}$ nálezu sa našiel analogický fragment $\mathrm{v}$ Radzovciach v objekte 40. Je považovaný za deštrukciu kovolejárskej pece, ktorá pravdepodobne súvisí s objektom 48, interpretovaným ako kovolejárska dielňa. Mazanicu s výčnelkom možno na základe absencie funkčných alebo výzdobných analógií predbežne považovat’ za funkčnú, alebo výzdobne 


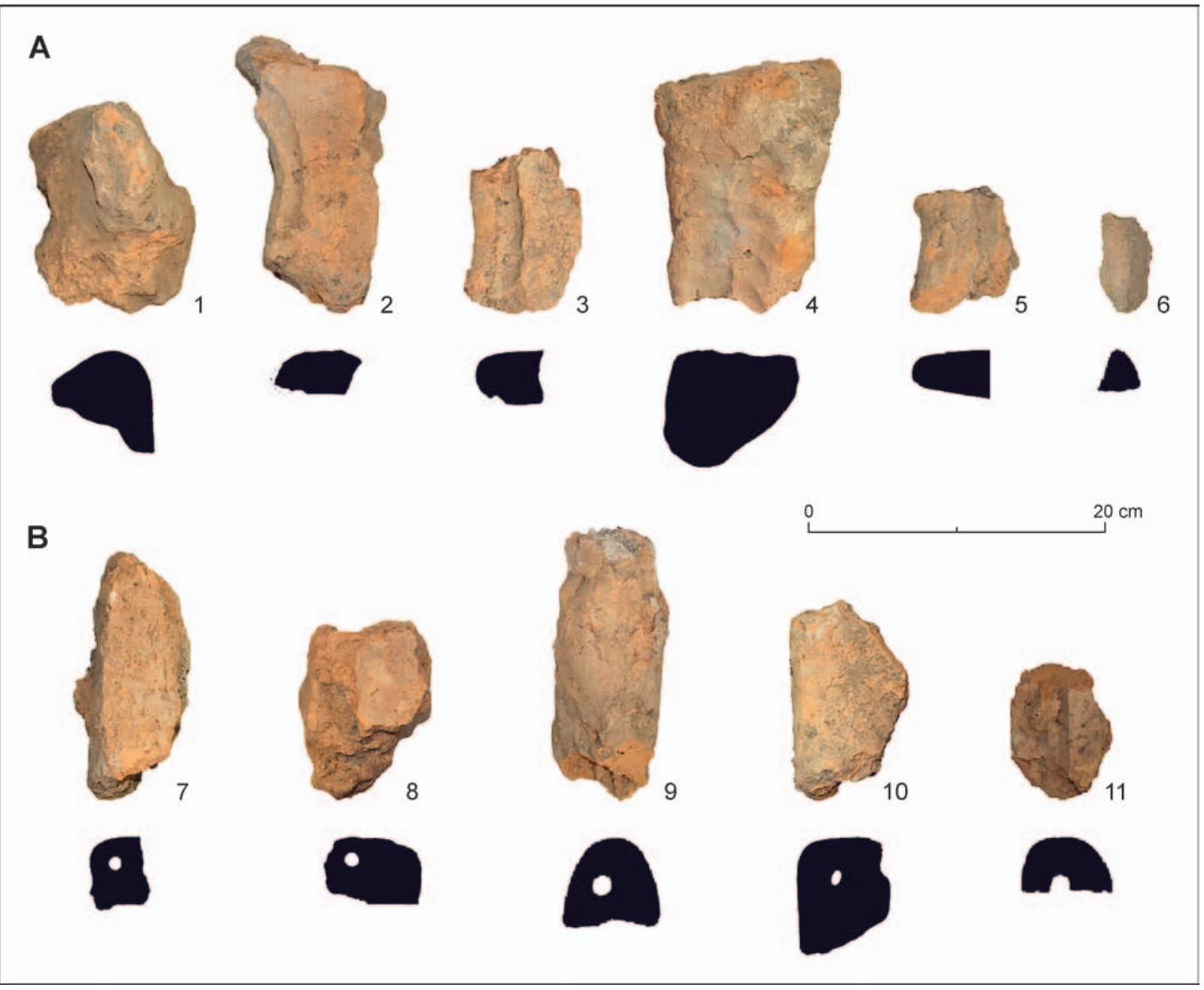

Obr. 4. Nižná Myšla-Várhegy. Mazanica zo sídliskových jám. A - fragmenty plasticky upravenej mazanice, ktorá bola súčastou architektonického alebo ozdobného prvku; B - mazanica s otvormi po prútí.

plasticky modelovanú $\mathrm{s}$ plošným povrchovým omazom z interiérového zariadenia (noha/držadlo/ roh?; Ďuriš 2018, 56). Mazanice s otvorom (obr. 4: B), pravdepodobne po prútoch, mohli byt' s ohladom na nálezové okolnosti súčastou výzdobného prvku ohniska, pece, alebo iných výzdobných architektonických prvkov stavieb (Kmetová/Hladíková/Gregor 2010, 151-154).

\section{Pyrotechnologické zariadenie v sonde 56C}

V sonde 56C bola odkrytá d’alšia deštrukcia pece, pričom jej horná vrstva pozostávala z dočervena prepálenej vrstvy s obsahom keramiky. Pod črepmi sa nachádzali nahusto naukladané cicváre, stále však nájdené v rámci dočervena prepálenej vrstvy. Predpecná jama obsahovala popol, pričom dno a steny boli vyložené kameňmi. V južnej časti pece sa kamene koncentrovali do tvaru písmena $\mathrm{L}$ (Szabová 2019, 48, obr. 17).

\section{Pyrotechnologické zariadenie v objekte 577}

Zhluk kameňov sa nachádzal aj na povrchu sídliskového objektu 577. V horných vrstvách objektu bolo zachytené pyrotechnologické zariadenie, ktoré predbežne považujeme za deštrukciu pece (obr. 5: 2). Hornú čast’ zariadenia tvorila pravdepodobne zborená klenba, resp. steny pece, ktorá sa zachovala vo forme väčších kusov do červena prepálenej hliny. Pod ňou sa nachádzalo niekol'ko keramických fragmentov, ktoré mohli byt๋ pôvodne súčastou konštrukčného riešenia dna pyrotechnologického zariadenia. Samotné dno tvoril estrich vytvorený vplyvom vysokej teploty. Pod ním sa nachádzala hrubá vrstva drobného štrku premiešaného s hlinou (obr. 5: 1). Z tej sa vplyvom kontaktu s vysokými teplotami po vyschnutí hmoty stala pevná a kompaktná vrstva. Pod ňou sa nachádzala vrstva hnedej hliny, v ktorej boli v rade uložené väčšie kamene. Ďalšiu vrstvu tvorila premiešaná hlina s popolom 


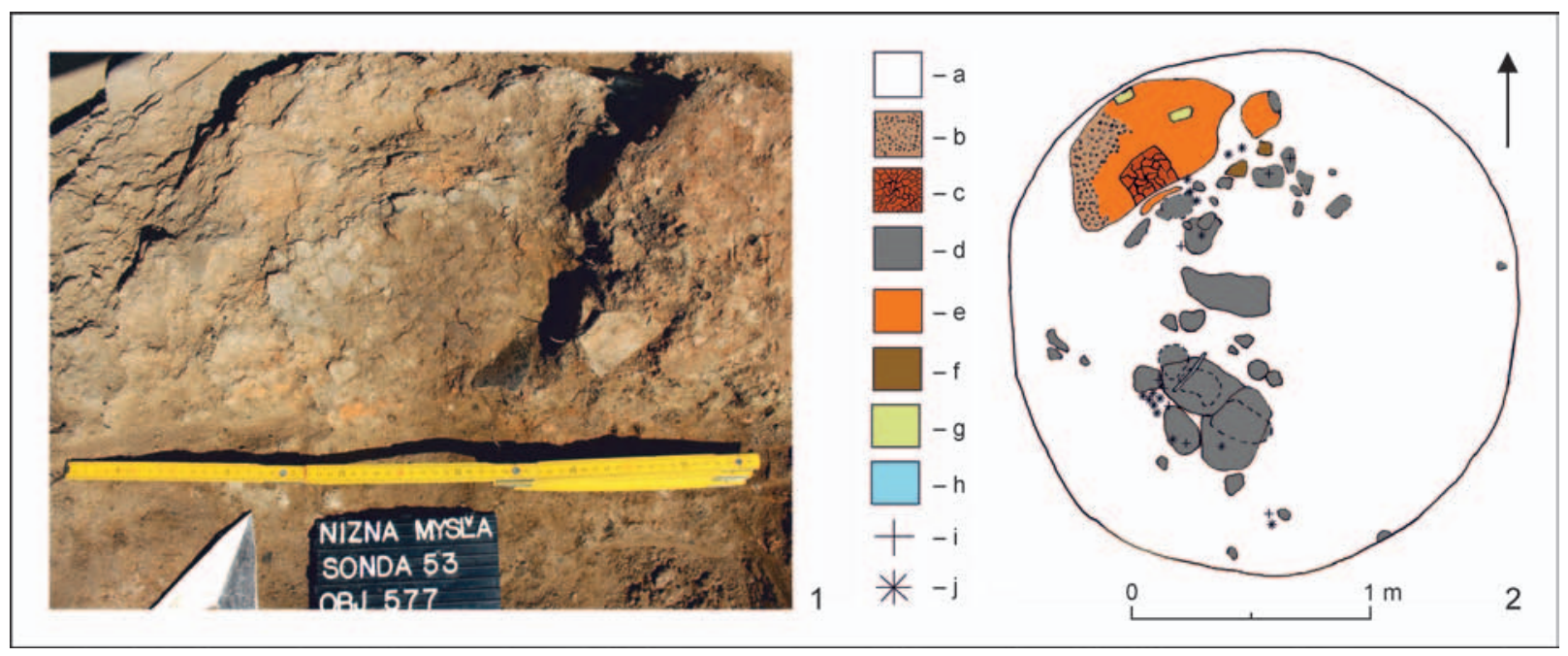

Obr. 5. Nižná Myšla-Várhegy. 1 - deštrukcia pece v objekte 577; 2 - pôdorys vrstvy v ktorej sa nachádzala deštrukcia pece. Legenda: a - premiešaná popolovitá a hnedá hlina; $\mathrm{b}$ - kamienky premiešané s hlinou vo vrstve pod estrichom; $\mathrm{c}-\mathrm{estrich}$, spodok pece; d - kameň; e - prepálená hlina; f - črep; g - tuf/tufit; h - zvieracia kost' (rebro); i - zvieracia kost; j - črep.

a uhlíkmi. Poslednú vrstvu tvorila hnedá kompaktná hlina. Opísaná stratigrafia sa zistila len v časti, v ktorej sa nachádzalo pyrotechnologické zariadenie. V nižších vrstvách, situovaných juhovýchodne od predpokladanej pece, sa nachádzala hrubá dočervena prepálená vrstva. Aj ked'v tomto prípade nešlo o technologicky zložitejšie zariadenie, môžeme predpokladat', že po strate pôvodnej funkcie sa staré pyrotechnologické zariadenie prekrylo zeminou a nahradilo novým (Olšav/Olexa 2020, 29).

\section{HROBY KOVOLEJÁROV}

Mimoriadne znalosti potrebné na výrobu kovových artefaktov, rovnako ako špecifické hrobové inventáre obsahujúce predmety nevyhnutné $\mathrm{k}$ ich spracovaniu, indikujú existenciu špecializovaných remeselníkov - kovolejárov. Činnost’ kovolejárov pozostávala z viacerých pracovných postupov, od tažby suroviny, tavenia, odlievania, až po tepanie a finálne úpravy produktu. Metalurgická výbava hrobov na pohrebiskách doby bronzovej napovedá o regulárnom pôsobení metalurgov v spoločnosti (Pančíková 2008, 69). G. Childe (1930, 45) charakterizuje kovolejárov ako kočovných remeselníkov. Avšak keď̌̌e stopy po odlievaní bronzu nachádzame aj na menších sídliskách, môžeme teóriu o kočovných remeselníkoch poprieł' (Fontijn 2002, 28). Taktiež vzhladom na pokročilý stav archeologického bádania v spojitosti s etnologickými prameňmi sa o metalurgovi ako potulnom remeselníkovi neuvažuje (Pančíková 2008, 69).

V Nižnej Myšli boli odkryté dva hroby kovolejárov zo staršej doby bronzovej (Olexa 1987). V oboch hroboch boli pochovaní dospelí muži s výrazne odlišným hrobovým inventárom. Z hladiska metalurgie obsahoval hrob 133 dvojdielny kadlub, slúžiaci na odlievanie šidiel. Okrem tohto predmetu dopĺńalo hrobový inventár sedem kančích klov, ktoré mohli spĺňat funkciu klieští vzhladom k svojej tepelnej nevodivosti (obr. 6: 2, 3). Neporovnatel'ne bohatší bol hrob 280 (obr. 7), ktorý pozostával z masívneho kamenného mlatu, slúžiaceho na drvenie rudy. Objavená bola aj hlinená dýza spolu s dvojdielnym kadlubom, ktorý sa používal na odlievanie ihlíc s gulovitou hlavicou, rovnako ako bronzová ihlica s gulovitou hlavicou, ktorá bola odliata v spomínanej forme. Vedla panvy boli umiestnené tri perforované kančie kly. Spolu s nimi sa v hrobe nachádzali dve kostené šidlá, parohová opasková pracka, bronzový náramok, kombinovaný náramok z bronzových trubičiek a mušlí, obsidiánová čepiel'ka, perforované nášivky z kančích klov a tri keramické nádoby (Olexa 2003, 59; Olexal Nováček 2013, tab. 135; 136). Súbor predmetov v opísanom hrobe poukazuje na výnimočné postavenie pochovaného muža v rámci vtedajšej komunity. Vek úmrtia oboch jedincov spadá na základe výsledkov analýz $\mathrm{C}^{14}$ metódou AMS, realizovaných v laboratóriu v Poznani, do obdobia medzi roky 1965-1754 BC (95,4 \%; Jaeger/Olexa 2014, 170). V kontexte vybavenosti hrobov oboch jedincov je možné uvažovat o rozličnom postavení metalurgov už $\mathrm{v}$ tomto období, kedy sú znalosti metalurgie už pomerne rozšírené (Jaeger/Olexa 2014, 173; Kienlin 2007). Tento názor podporuje kvalitatívna škála bronzových výrobkov, od jednoduchých predmetov bežnej potreby nachádzajúcich sa $\mathrm{v}$ rôznych sídliskových kontextoch, až po technologicky vyspelejšie predmety 


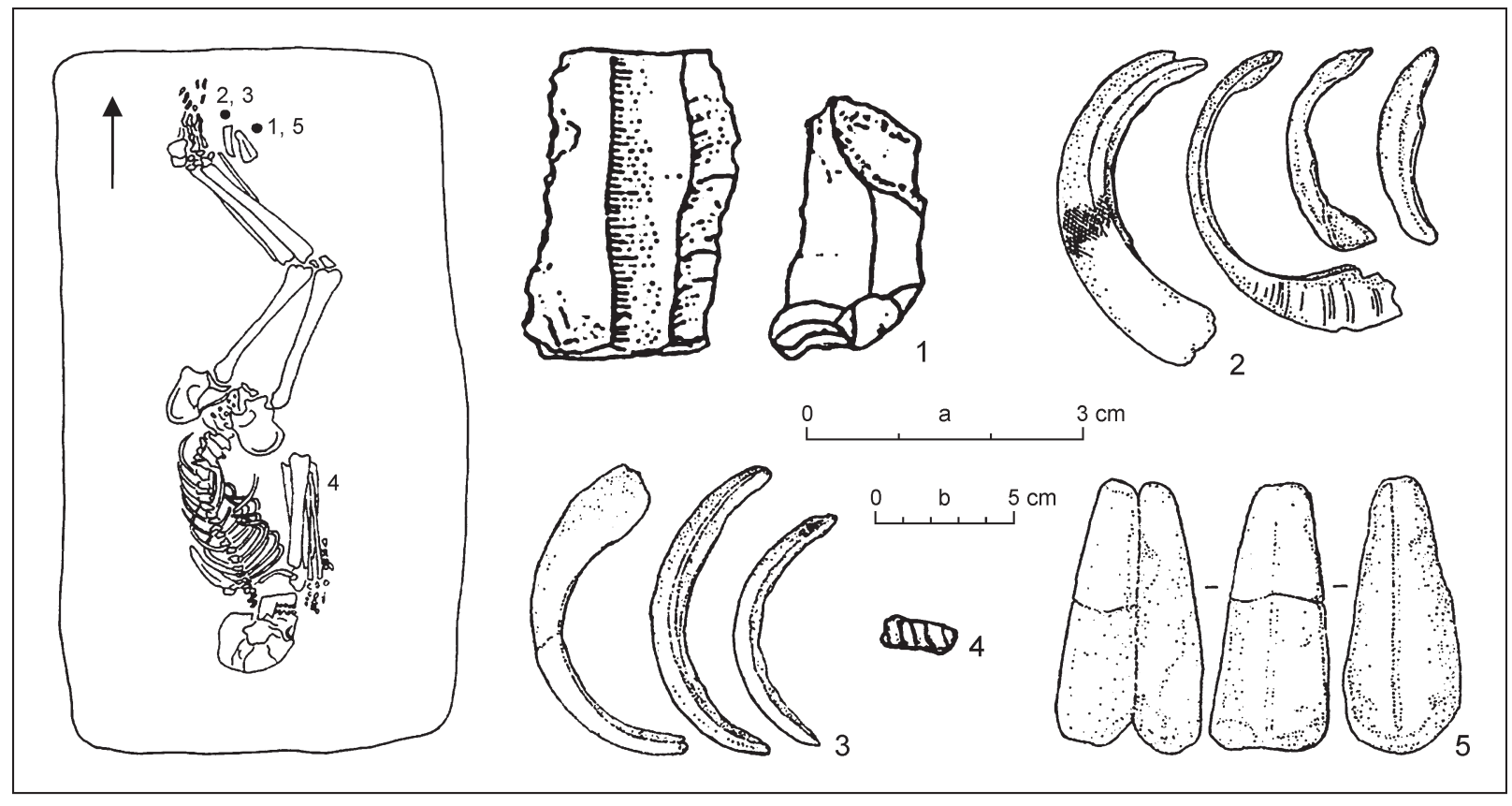

Obr. 6. Nižná Myšla-Várhegy. Inventár hrobu 133. 1 - štiepaná industria; 2, 3 - kančie kly; 4 - špirálovitá rúrka; 5 - dvojdielny kadlub z tufitu. Mierka: a - 1, 4; b - 2, 3, 5 (Olexa/Nováček 2013, tab. 63: 133).

prestížneho a náboženského charakteru (Jaeger/ Olexa 2014, 173). Oba unikátne hroby sú datované do predklasického stupňa OFKK, resp. do staršej doby bronzovej.

\section{PRIAME DOKLADY METALURGICKEJ ČINNOSTI}

\section{Tégliky}

Na rozdiel od hotových bronzových artefaktov, predstavujú tégliky a odlievacie formy priame doklady o spracovávaní neželezných kovov (Bayleyl Crossley/Ponting 2008, 12). Z objektu 519 pochádzajú dva hlinené kompletne zachované tégliky kvapkovitého tvaru, ktoré nesú stopy bronzoviny (tab. I: 1, 2). V objekte 519 bolo objavených aj d’alších šest’ fragmentov so stopami po tavení/odlievaní (tab. I: 3-8; Szabová 2017, 24). Hlina, z ktorej boli tégliky vyrobené, musela $\mathrm{v}$ prvom rade odolávat teplotám až do výšky $1300{ }^{\circ} \mathrm{C}$. Zároveň musela byt’ odolná voči rýchlemu ochladeniu sa. Vd’aka minimálnej tepelnej vodivosti hliny, má vonkajšia strana téglika pri použití výrazne nižšiu teplotu, pričom vo vnútri téglika je už požadovaný kov roztavený (Freestone 1989, 157).

Keramické tégliky sú zvyčajne redukčne vypálené, aby sa zabránilo oxidácii kovov priamo v tégliku. Sú preto charakteristické šedou až čiernou farbou (Bayley/Crossley/Ponting 2008, 12). Nálezy téglikov z objektu 519 sú pomerne hrubé a pórovité, čo im zabezpečovalo potrebnú tepelnú izolovanost’ a udržanie vyžadovanej teploty (Bayley/Rehren 2007, 46). Tégliky môžu byt dokladom odlievania farebných kovov priamo v objekte. Ďalšie analógie týchto predmetov pochádzajú aj z iných odpadových jám, preskúmaných na opevnenom sídlisku II v Nižnej Myšli (Olexa 2003, 53).

\section{Odlievacie formy}

Ďalším výrazným priamym dokladom lokálnej metalurgie na opevnenom sídlisku II sú odlievacie formy. Objavených bolo 37 kamenných kadlubov a ich zlomkov. O využívaní hliny ako doplnkovej suroviny pri výrobe kadlubov by mohlo svedčit niekolko sekundárne prepálených hlinených exemplárov s negatívom v tvare „vaničky“. Ostatne, nálezy zo Slovenska a Mad’arska (napr. z lokality Várvölgy-Kis-Láz-hegy), dokladajú používanie hlinených kadlubov až do neskorej doby bronzovej (Szabó 1996, 268-270). Zo súdobej lokality, opevneného sídliska v Spišskom Štvrtku, pochádza až pät’ exemplárov hlinených kadlubov (Oravkinová 2018, 163). V rámci nálezov z Nižnej Myšle išlo z väčšej časti o fragmenty jedno- a dvojdielnych odlievacích foriem, a v jednom prípade o trojdielny kadlub (tab. II). Z identifikovaných negatívov sa dali vyčlenit nasledujúce typy kadlubov: kadluby na odlievanie plochých sekier (štyri; tab. II: 13, 14), kadluby na odlievanie kopijí/ 


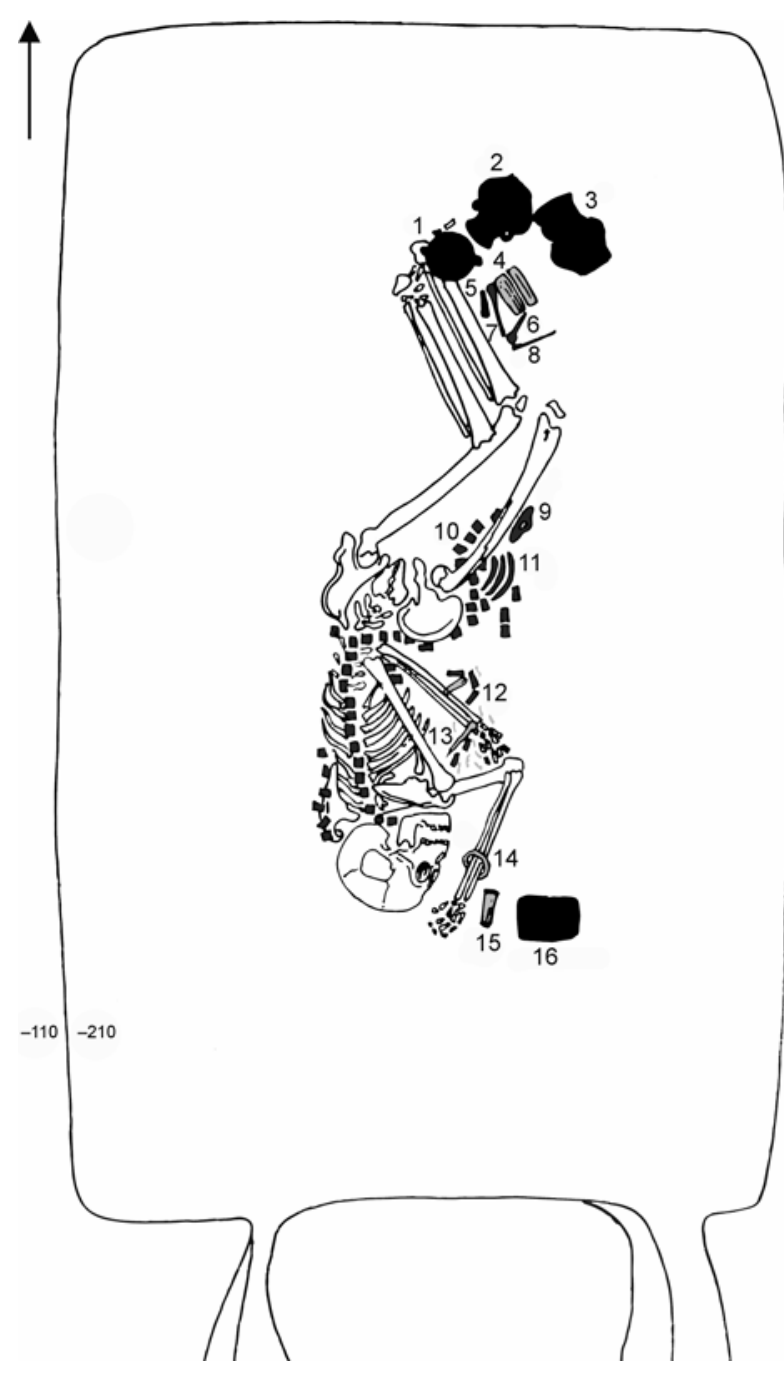

Obr. 7. Nižná Myšla-Várhegy. Inventár hrobu 280. 1 - dvojuchá nádoba; 2 - amfora; 3 - džbán; 4 - dvojdielny kadlub; 5 - čepel’ z obsidiánu; 6 - kostené šidlo; 7 - kostené šidlo; 8 - bronzová ihlica; 9 - pracka z parohoviny; 10 - nášivky z kančích klov; 11 - prívesky z kančích klov; 12 - mušle, bronzové špirálky a bronzové trubičky; 13 - bronzová ihlica s gulovitou hlavicou; 14 -bronzový náramok; 15 - hlinená dýza; 16 - kamenný mlat.

oštepov (dva; tab. II: 10, 15), kadluby na odlievanie plochých predmetov - dýk/nožov (tri, stav zachovania nedovoluje presné určenie), kadlub na odlievanie dýk (jeden; tab. II: 11) kadlub na odlievanie plieškov (dva; Olexa 2003, tab. XV: 17), kadluby na odlievanie ihiel, šidiel a ihlíc (devät; tab. II: 2, 16, 17), kadluby na odlievanie tyčinkovitých predmetov so štvorcovým prierezom (dva), kadlub na odlievanie krúžkov (tri; tab. II: 7, 8) a kadlub na odlievanie hlavice ihlice s kotúčovitou hlavicou (tab. II: 18).

Z objektu 519 pochádza celkom osem fragmentov odlievacích foriem a jeden dvojdielny kadlub (tab. II: 1-8). Materiál, ktorý bol použitý na výrobu odlievacích foriem predstavuje lokálny tufit a importovaný pieskovec (Szabová 2017, 25). Pričom na prelome staršej a strednej doby bronzovej sú najpočetnejšími nálezmi kamenné kadluby z pieskovca. Pieskovcové odlievacie formy boli neskôr nahradené inými kamennými, hlinenými a kovovými formami, zrejme z dôvodu krehkosti pieskovca (Eccleston/Ottaway 2002, 189). Použitie odlievacích foriem môže makroskopicky dokladat sčernený alebo začervenaný povrch.

Na odlievanie kovových tyčiniek bol pravdepodobne používaný tufitový kadlub (tab. II: 2). Je vypálený do sýto oranžovej farby. Tyčinky mohli byt odlievané za účelom výroby polotovarov, ktoré boli neskôr sekundárne spracované. Podobne aj d’alšie odlievacie formy z objektu 519 boli vyrobené z tufitu. Významným nálezom je kompletne zachovaný dvojdielny kadlub obdížnikového tvaru, ktorý mohol slúžit na odlievanie bronzových krúžkov (tab. II: 7), ${ }^{2}$ rovnako ako d’alšia fragmentárne zachovaná forma (tab. II: 8). Analogické bronzové krúžky pochádzajú z lokality Celldömölk-Sághegy (Mozsolics/ Schalk 2000, tab. 126). Kadluby nevykazujú známky prepálenia, preto nie je vylúčené, že mohli mat̉ inú funkciu. Makroskopické pozorovanie predmetu nie je postačujúcim dôkazom pre vylúčenie možnosti, že negatívy na predmete boli využité na odlievanie a pre exaktnejšiu interpretáciu je nutné ich podrobit mikroskopickej analýze. Zaujímavý je fragment kamenného kadlubu s negatívom neznámeho predmetu (tab. II: 12). Najbližšiu analógiu nachádzame na tellovom sídlisku Ároktő-Dongóhalom, kde je fragment kadlubu s analogickým negatívom s otáznikom interpretovaný ako kadlub na odlievanie sekeromlatov (Fischl 2006, 98). Ostatné kamenné odlievacie formy zastupujú štyri zlomky, z toho tri v silne fragmentárnom stave bez bližšej vypovedacej hodnoty (tab. II: 3-5). V prípade zachovalého fragmentu je možné predpokladał jeho pôvodnú funkciu. Slúžil pravdepodobne na odlievanie bronzových ihlíc (tab. II: 6; Szabová 2017, 25).

Zvlášt vzácnym nálezom je čast' pôvodne trojdielneho kadlubu na odlievanie ihlíc s kotúčovitou hlavicou vyrobený z pieskovca (tab. II: 18). Ihlice s kotúčovou hlavicou sa začínajú ojedinele vyskytovat už v mladšom klasickom stupni BA3 na pohrebisku v Nižnej Myšli (Nováček 2017, 85). Pokračujú aj počas stupňa BB1, kde sú zachytené aj priamo na opevnenom sídlisku v Spišskom Štvrtku (Oravkinová 2018, 215), ale aj v Košiciach-Barci (Novotná 1980, 48 n.). Tento typ ihlice, nazývaný typ Barca, sa všeobecne chronologicky zaraduje do obdobia kosziderského horizontu (Găvan 2013, 146; Novotná 1980, 49).

\footnotetext{
2 Za informáciu d’akujeme G. Szabóovi.
} 
Tabela 1. Nižná Myšla-Várhegy, objekt 519. Výsledky spektrálnej analýzy povrchu hlineného tégliku so stopami po odlievaní farebného kovu. Analýzu vykonala Zuzana Felcanová.

\begin{tabular}{|c|c|c|c|c|c|c|c|c|c|c|c|c|}
\cline { 2 - 17 } \multicolumn{1}{c|}{} & $\mathbf{C u}$ & $\mathbf{S n}$ & $\mathbf{S b}$ & As & Fe & Ni & Zr & Zn & W & Co & Mn & Cd \\
\hline$[\%]$ & 39,01 & 43,57 & 0,48 & 0,54 & 7,95 & 0,76 & 0,11 & 5,14 & 1,57 & 0,16 & 0,28 & 0,1 \\
\hline
\end{tabular}

Tabela 2. Nižná Myšla-Várhegy, objekt 519. Výsledky spektrálnej analýzy bronzového zliatku. Analýzu vykonala Zuzana Felcanová.

\begin{tabular}{|c|c|c|c|c|c|c|c|c|c|c|c|c|c|}
\cline { 2 - 12 } \multicolumn{1}{c|}{} & $\mathbf{C u}$ & $\mathbf{S n}$ & $\mathbf{S b}$ & $\mathbf{A s}$ & $\mathbf{F e}$ & $\mathbf{N i}$ & $\mathbf{Z r}$ & $\mathbf{P b}$ & $\mathbf{B i}$ & $\mathbf{T i}$ & $\mathbf{A l}$ & $\mathbf{P}$ & $\mathbf{S i}$ \\
\hline Miesto merania 1 [\%] & 55,83 & 15,97 & 0,82 & 1,42 & 1,09 & 0,23 & 0,01 & 8,74 & 0,1 & 0,26 & 3,71 & 0,23 & 11,17 \\
Miesto merania 2 [\%] & 55,3 & 19,04 & 0,48 & - & 1,99 & 0,21 & 0,1 & 6,6 & 0,07 & 0,27 & 3,98 & 0,32 & 11,55 \\
\hline
\end{tabular}

Kadluby kopijí/oštepov, kadlub dýky a kadlub na odlievanie zlatých plieškov majú taktiež analógie vo forme hotových bronzových výrobkov priamo na opevnenom sídlisku v Nižnej Myšli (Olexa 2003, obr. 57, tab. XII). Zlaté pliešky sú interpretované ako nákončia na šnúrky, ktoré boli súčastou odevu a našli sa len v zlatom prevedení výhradne v starších hroboch (Olexa 2003, obr. 57). Na rozdiel od nich sú kadluby plochých sekier typickým nálezom v Karpatskej kotline počas trvania tzv. tellových kultúr v staršej a strednej dobe bronzovej, na čo poukazuje pomerne početný výskyt týchto predmetov (Găvan 2013, 86-88). Nechýbajú ani na opevnenom sídlisku v Nižnej Myšli, kde boli identifikované štyri exempláre. Unikátny je nález kompletne zachovaného negatívu na kadlube, ktorý bol určený na odlievanie bronzových dýk. Kadlub bol objavený v objekte 177 ktorý slúžil ako zemník a následne ako odpadová jama osady I. Kadlub teda môže súvisiet' aj so starším horizontom, avšak tento typ predmetu nie je možné presne chronologicky zaradit. Jednoznačne unikátny nález, ktorý je v kontexte OFKK pomerne vzácny, je bronzový hrot kopije nájdený na opevnenom sídlisku I v Nižnej Myšli (Gašaj/Olexa 1996, 4). Fragmenty dvoch kadlubov s negatívom štvorcového prierezu nie je možné s určitostou interpretovat.' Mohlo by íst' o šidlo alebo dlátko, ked’že práve tie sú charakteristické profilom v tvare štvorca (napr. Găvan 2013, tab. 69; 47). Avšak štvorcový prierez majú taktiež ingoty, ktoré mohli slúžit ako surovina alebo polotovar určený na dalšie spracovanie (Luštík/Mihok/Olexa 1991, 143).

Zvyšné tufitové kadluby so známkami prepálenia sa dochovali $\mathrm{v}$ stave zlomkov a ich presnejšie určenie nie je možné.

\section{Výsledky spektrálnych analýz}

Röntgenfluorescenčná analýza je metóda založená na vyvolaní a detekcii charakteristického žiarenia. Prostredníctvom tejto nedeštruktívnej analytickej metódy boli vyhotovené rozbory dvoch vybraných artefaktov z objektu 519. Analýza bola vykonaná Mgr. Zuzanou Litviakovou, PhD., pomocou prístroja Nilton XL3t. Cielom bolo zistit približné zastúpenie prvkov vo vybraných predmetoch. Prvým skúmaným predmetom bol kompletne zachovaný hlinený téglik s viditel’nými mikro zvyškami zliatkov (tab. I: 2). Téglik nesie výrazné stopy medi a cínu (tabela 1). Vykonanou analýzou bolo preukázané, že téglik mohol slúžit na odlievanie bronzovej zliatiny (prvky, ktoré neboli počas meraní zastúpené, sa v tabul'ke nenachádzajú; Szabová 2017,31). Druhý meraný artefakt predstavuje zliatina farebného kovu - surovina, ktorá nebola následne d’alej spracovaná (tab. III: 17). Merania na zliatine boli vykonané na dvoch miestach a preukázali, že obsahuje med’ a cín s pomerne vysokým obsahom olova (tabela 2). Tu je dôležité zdôraznit, že namerané hodnoty sú z povrchových koróznych vrstiev, v ktorých býva štandardne nadhodnotený obsah prvkov cínu a železa a podhodnotený obsah medi (Nørgaard 2017, 104, 112 n.).

Uvedené výsledky dopíňajú metalografické analýzy 12 kovových artefaktov z osady II z Nižnej Myšle, ktoré boli realizované v roku 1989 pomocou energiovo disperzného analyzátora EDAX 9100/60, pracujúceho na elektrónovom mikroskope Tesla BS 300 (Luštík/Mihok/Olexa 1991, 140). Tieto analýzy rovnako potvrdili, že predmety boli vyrobené z bronzu. Spektrálna analýza mala preukázat', že skúmané bronzové artefakty obsahovali med', ktorá je vel'mi blízka medi z povrchových ložísk Slovenského rudohoria v oblasti ned’aleko Košíc, resp. z ložísk v blízkosti Bankova (Luštík/Mihok/Olexa 1991, 144; Olexa 2003, 61). Túto hypotézu je však nutné overit pomocou novších analytických postupov (Jaeger 2016, 120). Zdroj cínu z Nižnej Myšle nebol doteraz identifikovaný (Olexa 2003, 61). Možný zdroj cínu v podobe kassiteritu (75/78 \% cínu) sa nachádza $\mathrm{v}$ podobe cínovo-nosných naplavenín, ktoré boli 
následne exploatované ryžovaním (Furmánek 2015, 276). Podla Pernicku $(1998,138)$ mohol byt' kassiterit objavený ako vedlajší produkt popri ryžovaní zlata, nakol'ko majú oba kovy charakteristickú vyššiu hmotnost' a sú odolné voči zvetrávaniu. Nie je preto vylúčené, že v oblasti východného Slovenska bol kassiterit $\mathrm{v}$ dobe bronzovej získavaný práve ryžovaním. Vo východnej časti Slovenského rudohoria možno predpokladat ryžovanie kassiteritu v nasledovných oblastiach: Čučma, Betliar, Poproč, povodie Hnilca (Furmánek 2015, 276). Ďalším z eventuálnych zdrojov pre dovoz cínu na územie Slovenska bola oblast' Krušných hôr, kde bola medzičasom tažba cínu v dobe broznovej potvrdená (Furmánek/Veliačik/ Vladár 1991, 219; Tolksdorf a i. 2019, 16). Súčasne sa nevylučuje ani distribúcia cínu z ložísk z územia západnej Európy, resp. z južného Anglicka (Nessel a i. 2018, 70; Novotná 2010, 271). Avšak aktuálny stav bádania poukazuje na ustálené zdroje cínu pre túto čast' Európy v druhom tisícročí pred n. 1. (pochádzajúce dokonca snád’ len z jednej oblasti), ako pravdepodobnejší zdroj sa preto javí cín z oblasti Krušných hôr (Nessel a i., 70). Aj napriek skutočnosti, že sa cín ako ruda nenachádza v mnohých oblastiach s kovolejárskou tradíciou, bol základným a žiadúcim prvkom, ktorý vytvoril d’alšie evidentné obchodné siete (Tzachili 2008, 21). Na prítomnost’ cínu na opevnenom sídlisku II v Nižnej Myšli nepriamo poukazuje chemická analýza na vybraných kamenných nástrojoch, ktoré boli interpretované ako brúsiky, či skúšobné kamene. Aj ked’ sa na jednom $\mathrm{z}$ exemplárov nachádzali stopové prvky čistého cínu, tieto samotné nemožno pokladat za dostatočný dôkaz o fyzickej prítomnosti cínovej zásoby na opevnenom sídlisku. ${ }^{3}$

\section{VÝBER KOVOVÝCH ARTEFAKTOV}

Väčšina negatívov odlievacích foriem má svoje typologické náprotivky $\mathrm{z}$ bronzu priamo $\mathrm{z}$ opevneného sídliska v Nižnej Myšli. Avšak k viacerým bronzovým predmetom stále chýbajú korešpondujúce odlievacie formy. Ich absencia môže byt’ spôsobená stavom výskumu. Nie je vylúčené, že nasledujúcim výskumom sa podarí rozšírit aj typologickú základňu negatívov odlievacích foriem. Už z pohladu súčasného stavu spracovania je zrejmé, že tvoria mimoriadne reprezentatívny súbor nálezov tohto druhu. Opevnené sídlisko v Nižnej Myšli tak možno považovat' za významné metalurgické centrum s kontinuitou, ktorá siaha už do staršej doby bronzovej. Tomu nasvedčujú početné kovové nálezy získané z opevnenej osady I a zvlášt z ko- rešpondujúceho pohrebiska. Aj ked’ je zrejmé, že určité množstvo objavených bronzových predmetov neboli výrobky tunajšej produkcie, predpokladáme, že vel'ká čast’ z nich bola vyrobená priamo na opevnenom sídlisku. Vysoký počet hotových produktov je taktiež nepriamym dokladom opakovanej metalurgickej činnosti a zároveň sú dôležitým zdrojom informácii pre riešenie mnohých otázok týkajúcich sa problematiky OFKK. V štúdii predkladáme len výber kovových artefaktov objavených v objekte 519 a v remeselnom areáli v severovýchodnej časti opevneného sídliska II v Nižnej Myšli. Celkovo si ale množstvo objavených nálezov bronzových predmetov zasluhuje d’alšie budúce samostatné spracovanie.

\section{Šperk}

Záušnice z Nižnej Myšle boli bežne používané od predklasického stupňa BA2, nakol'ko sa tu stretávame s nálezmi sibinských záušníc v najstaršej časti pohrebiska (Nováček 2010, 45). Sibinské, alebo tzv. sedmohradské záušnice nachádzame v celom priestore Karpatskej kotliny (Stejskalová 1999, 88). Záušnice srdcovitého typu boli vyrábané z tepanej tyčinky, ktorá bola na oboch koncoch preložená cez seba. Lod'kovitý typ záušníc je podobný srdcovitému, až na to, že môže byṫ jedno rameno ohnuté o jeden, príp. dva oblúky navyše. Z objektu 519 pochádza jedna bronzová sibinská záušnica lod'kovitého typu (tab. III: 18; Stejskalová 1999, 89). Je trojlod'ková s hranením v oblasti kýlu, pričom obdobná záušnica pochádza priamo z pohrebiska z Nižnej Myšle, z hrobu 320 (Olexa/Nováček 2015, 102). Záušnice lod'kovitého typu so spätne otočeným ramenom boli rozšírené prevažne v oblasti východného Slovenska na lokalitách osídlených OFKK v období prelomu staršej a strednej doby bronzovej (napr. Nižná Myšla, Barca I, Spišký Štvrtok). V porovnaní s únětickými záušniciami sú väčšie a širšie (Stejskalová 1999, 87).

Liata záušnica bola objavená aj v objekte 563 (obr. 8: 6). Možno ju na základe vytočenia ramien priradit' k srdcovitému typu (Szabová 2019). Bronzové záušnice analogického tvaru boli objavené v najstaršej, západnej, časti pohrebiska v Nižnej Myšli, ktorá je datovaná do stupňa BA2. V inventároch hrobov patriacich do mladšej časti pohrebiska, datovaného do klasického stupňa periodizácie sa záušnice tohto typu vyskytujú len sporadicky, pričom boli vyrábané výhradne zo zlata (Nováček 2017). Podobné záušnice sa všeobecne vyskytujú aj v období strednej a mladšej doby bronzovej, pričom

\footnotetext{
${ }^{3}$ Mikrochemickú analýzu vykonal Mgr. Martin Ježek Ph.D., z Archeologického ústavu Akadémie vied Českej republiky.
} 


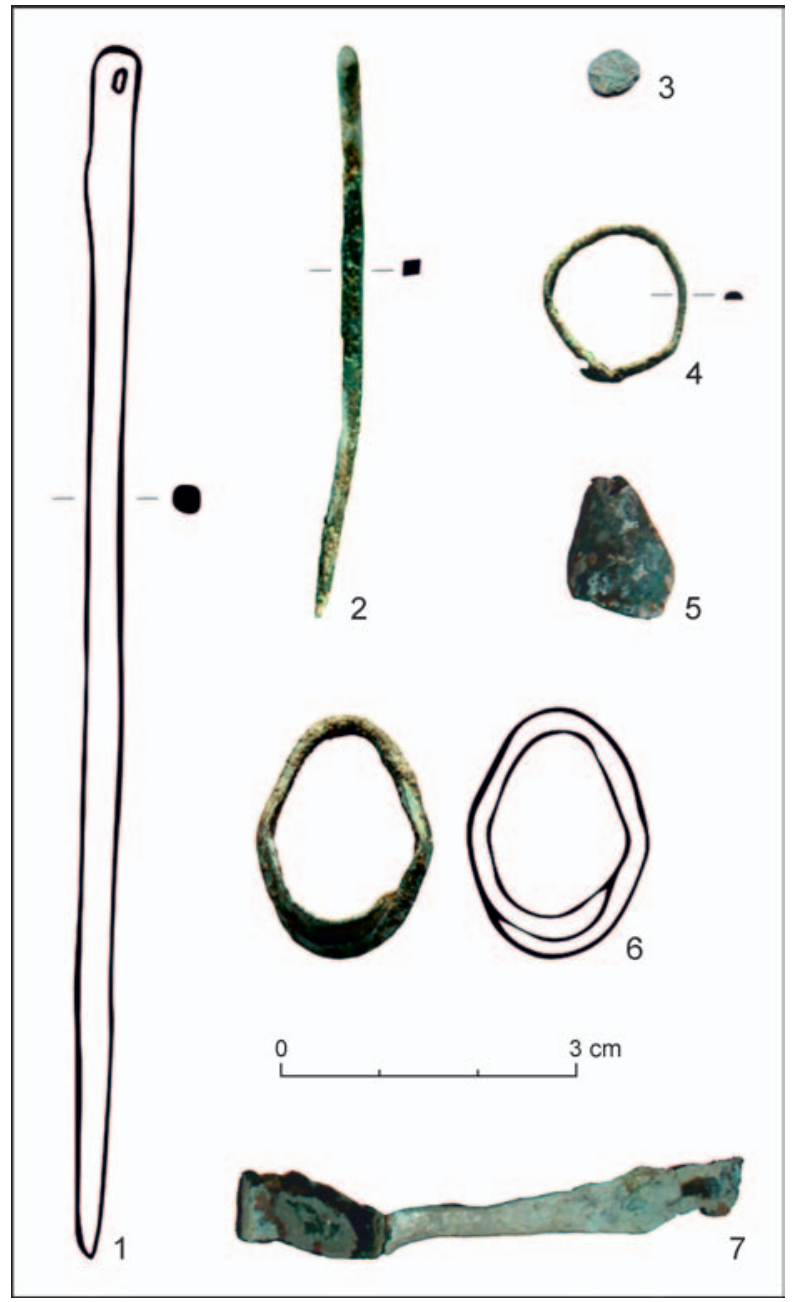

Obr. 8. Nižná Myšla-Várhegy. Výber kovových artefaktov zo severovýchodnej časti opevneného sídliska II.

sa nachádzajú v bronzovom aj v zlatom prevedení (Lamiová-Schmiedlová 2009, tab. 43: 11; Oravkinovál Vladár 2021; obr. 4: 5-9; 5: 1-4; 6: 5-13; Pástor 1955, obr. 33). Technologické prevedenie naznačuje, že záušnica patrí do strednej doby bronzovej, teda na začiatok tohto obdobia a je súčasná s opevneným sídliskom II v Nižnej Myšli.

Čo sa týka prsteňa s viacnásobne stočeným drôtom (tab. III: 19), analógie nachádzame od staršej doby bronzovej až po obdobie popolnicových polí (Dzurušová 2012, 19). Druhým typom je špirálovito skrútený liaty prsteň s pr. $1,5 \mathrm{~cm}$ (tab. III: 20). Fragment liateho prsteňa bol objavený napr. $\mathrm{v}$ detskom hrobe 153 v Nižnej Myšli (Olexa/Nováček 2013, 35).

Kovový fragment krúžku (obr. 8:4) s pr. 1,5 cm bol objavený $\mathrm{v}$ dočervena prepálenej vrstve, $\mathrm{v}$ ohnisku vyloženom kameňmi, v objekte 570 (Szabová 2019, 63). Pravdepodobne ide o šperk, respektíve súčast’ prsteňa, ktoré poznáme napríklad z pohrebiska v Nižnej Myšli (Olexa/Nováček 2015, obr. 12: 1-6).
Okrem menovaných nálezov bol v preskúmanom objekte 519 objavený jeden liaty kovový korálik (tab. III: 21; Szabová 2017, 20). Koráliky rovnakého tvaru a vel'kosti pochádzajú z opevneného sídliska II z kombinovaného náhrdelníka (Olexa 2003, 5, 88).

Pozoruhodným nálezom je tenký zdobený pliešok s dížkou $3 \mathrm{~cm}$ (tab. III: 28). Na povrchu pliešku sa v hornej a dolnej časti nachádzajú mierne vystúpené línie, ktoré začínajú od nitu. Okrem línií sú v stredovej časti viditelné štyri plné, po okrajoch vystúpené krúžky. Posledný, v poradí piaty krúžok je prederavený, aby mohol byt' prinitovaný do začiatočnej časti plieška. Ozdobný pliešok je zo zadnej strany hladký. Analógia k pliešku pochádza

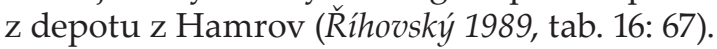

\section{Súčasti odevov}

Ku kategórii predmetov, ktoré boli pôvodne súčastou odevov prináležia dva zachované bronzové gombíky (tab. III: 26, 27). Oba gombíky majú na zadnej strane pritavené uško, ktorým boli prišité k odevu. Majú hladký povrch s vyklenutou profiláciou. Perla uprostred gombíka sa na exemplároch nevyskytovala. Početný súbor podobných gombíkov zo Slovenska pochádza z Dvorníkov-Včelár z hrobu H28 (Dzurušová 2012, 22). Nálezy gombíkov poznáme prevažne v Mad’arsku, napr. na lokalitách Bölcske, Méhi, Vukovár a Lovas (Mozsolics 1967, 94), alebo na lokalite Celldömölk-Sághegy (Mozsolics/ Schalk 2000, tab. CXXVI: 29-37).

Metalografická analýza preukázala, že kovové predmety z lokality Nižná Myšla-Várhegy boli výhradne odlievané, nie tepané. Jedine $\mathrm{v}$ prípade zlatých artefaktov, ako sú jemné nášivky, bol finálny predmet upravený jemným tepaním alebo tlakom (Mihok/Olexa/Briančin 1998, 8). Rovnaký výrobný postup predpokladáme aj $\mathrm{v}$ prípade gombíkov vyrobených z bronzu. $Z$ chronologického hladiska ich nemožno zaradit do konkrétneho stupňa OFKK.

Medzi súčasti odevov, ktoré boli oblúbené nielen počas trvania OFKK patria s určitostou ihlice. $\mathrm{V}$ analyzovanej kolekcii fragment hlavice s horizontálne perforovanou vrchnou častou a kruhovou „klincovitou hlavicou" patril hornej časti ihlice (tab. III: 22). Na hlavici a ani na tele sa nenachádza žiadny dekor, pričom prierez tela má tvar štvorca. Analogická je ihlica zo Šaroviec, ktorú M. Novotná $(1980,52,53)$ na základe čiastočnej podobnosti priradila k ihliciam typu Majcichov. Avšak túto ihlicu nemožno konkrétne datovat', pretože pochádza z polykultúrneho objektu (mad’arovská kultúra, karpatská mohylová kultúra). Ďalšia analogická ihlica datovaná do strednej doby bronzovej sa našla v rámci depotu z Př́tlukov (David 2002, tab. 228). 
Ihlica s plochou kruhovitou hlavicou a štvorcovým prierezom pochádza aj z hrobu 752 z mad’arského pohrebiska Dunaújváros-Duna-dülö. Hrob patrí do neskorého kosziderského horizontu (Vicze 2011, 445). Podobná ihlica pochádza z inventára hrobu 2/1925 vo Wetzleinsdorfe (David 2002, tab. 316). Nálezy tohto typu ihlíc sa na základe vyššie opisovaných analógií vyskytujú počas dlhšieho časového obdobia strednej doby bronzovej. Objavený bol aj zlomok tordovanej ihlice bližšie neurčitel’ného typu (tab. III: 23).

Kompletne zachovaná bronzová ihlica bola nájdená pod kameňom vo východnej časti objektu 563 (obr. 8: 1; Szabová 2019, 62). Ide o ihlicu so slučkovitou hlavicou (podla Novotná 1980, tab. 48), ktorá je pomerne častým prvkom objavujúcim sa v hroboch v rámci inventáru na pohrebisku v Nižnej Myšli. Tieto ihlice sa nachádzali v deviatich hroboch (v skupine hrobov 1 až 310), patriacim do najstaršej fázy pochovávania (Olexa/Nováček 2013, 36). V dalších preskúmaných hroboch (hroby 311 až 499) sa nachádzalo $33 \mathrm{ks}$, pričom z metrického a výzdobného hladiska badat' určité zmeny (Olexal Nováček 2015). Ihlice sú dlhšie a nachádza sa na nich výzdoba v podobe horizontálnych rýh. Najpočetnejším typom ihlíc $z$ tejto časti pohrebiska sú ihlice so slučkovitou hlavicou a objavujú sa od počiatku využívania pohrebiska. Postupne však dochádza k zmenám dľžky a začína sa objavovat aj rytá výzdoba. Ihlice so slučkovitou hlavicou mali pravdepodobne predlohu $\mathrm{v}$ kostených a neskôr v bronzových ihlách na šitie (Olexa/Nováček 2015, 29). Nakol'ko však dížka ihlice z objektu 563 mierne prekračovala $100 \mathrm{~mm}$ (dĺžka ihly $-120 \mathrm{~mm}$ ) a nenachádzala sa v hrobe ale sídliskovej jame, môže íst' aj o pracovný nástroj, resp. ihlu (Nováček 2017, 83).

\section{Pracovné nástroje}

Bežnými predmetmi dennej potreby či pracovnými nástrojmi sú ihly. Bronzové ihly postupne nahradili ihly vyrobené z kostí a parohov, ktoré boli používané v staršej dobe bronzovej (Furmánek/ Ožd'áni 2015, 150). Fragment ihly s očkom a d’alší fragment polovice tela ihly dokladajú pravdepodobnú výrobu, používanie, alebo predstavujú odpad v objekte 519 (tab. III: 25). Ihly nie sú chronologicky citlivým artefaktom, ich výskyt nemožno ani bližšie geograficky vymedzit' (Novotná 1980, 168).

V objekte 562 sa v rámci kovových artefaktov klasifikovaných ako pracovné nástroje nachádzalo šidlo so štvorcovým profilom (obr. 8: 2; Szabová 2019, 62). Analogické šidlo pochádza zo sídliska v Spišskom Štvrtku, kde boli artefakty tohto typu pomerne často nachádzané. Nástroje mali tvar jednoduchých tyčiniek so zhrubnutou strednou častou, so štvorcovým alebo okrúhlym profilom a zahrotením na jednom alebo oboch koncoch (Oravkinová 2018, obr. 37: 425). V prípade šidla z objektu 562 ide o obojstranne zahrotené šidlo. Analogické šidlá sa našli aj v iných sídliskových kontextoch na opevnenom sídlisku II (tab. III: 24), ako aj v hroboch na pohrebisku v Nižnej Myšli, ktoré je súčasné s osadou I zo staršej doby bronzovej (Nováček 2017, 109).

\section{Artefakty výrobnej zložky}

Medzi hrivny možno zaradit fragment kruhovito stočenej tyčinky s trojuholníkovitým, príp. kvapkovitým prierezom z objektu 519 (tab. III: 9). Priemer kruhu dosahuje $4 \mathrm{~cm}$ a celková dížka fragmentu sa pohybuje okolo $7 \mathrm{~cm}$. Zlomok možno na základe prierezu interpretovat ako polotovar, no kvôli stavu zachovania má len nízku vypovedaciu hodnotu. V objekte 519 boli objavené aj tyčinkovité ingoty so štvorcovým alebo obdížnikovým profilom (tab. III: 1-4, 7, 8). Bronzové, príp. medené tyčinkovité hrivny zohrávali dôležitú úlohu v rámci výmenného obchodu a mohli byt určené na lokálne spracovanie miestnym kovolejárom (Vavák a i. 2015, 164). Tieto hrivny mohli slúžit ako polotovar, alebo pripravená surovina na d’alšie spracovanie (Luštík/Mihok/Olexa 1991, 144), prípadne boli zhotovené za účelom d’alšieho pretavenia alebo na distribúciu (Oravkinová 2018, 204, 205). Ďalšou z možností je, že boli vytepané do tvaru úzkeho tenkého plechu, zrolované, a tak pripravené do zásoby pre d’alšiu výrobu (obr. 8: 7; Oravkinová 2018, 205). Nálezy kamenných kadlubov s negatívmi tyčinkovitých hrivien dokazujú, že boli vyrábané priamo na opevnenom sídlisku. Nad objektom 568 boli koncentrované kamene, medzi ktorými sa nachádzala čast' podlhovastého pliešku, ktorý je na konci spätne ohnutý (obr. 8: 7; Szabová 2019, 63). Podobný pliešok bol objavený v Spišskom Štvrtku (Oravkinová 2018, obr. 36: 293). Je možné, že podlhovastý zvinutý pliešok bol medziprodukt vyrobený z vytepaného tyčinkovitého polotovaru, resp. ingotu (Oravkinová 2018, 205).

Počas celej doby bronzovej sa stretávame v sídliskových objektoch, ale aj v depotoch s malými amorfnými kúskami bronzu (Novotná 1982, 363). Takýto nález pochádza z objektu 519. Devät kusov trosky s približne rovnakými rozmermi a hmotnostou (cca $1 \times 0,5 \mathrm{~cm},>1 \mathrm{~g}$; tab. III: 13). Trosky vznikli ako odpad, ktorý bol vytvorený pri tepelnej manipulácii s bronzovou surovinou. Drobné amorfné zlomky farebného kovu pochádzajú aj zo zhlukujúcich sa jám v severovýchodnej časti opevneného sídliska II, predovšetkým z objektu 567, kde boli taktiež zachytené situácie súvisiace s metalurgickou činnostou (obr. 8: 3; Szabová 2019, 66). Aj samotné zvyšky výrobného odpadu, dokladajú lokálnu metalurgickú aktivitu. 
O plánovanom odlievaní svedčí nález bronzoviny plackovitého tvaru (tab. III: 17). Predmet bol podrobený analýze vykonanej pomocou nedeštruktívnej metódy RFA (pozri vyššie). Zliatok patrí podla K. Berňakoviča $(1961,30)$ do skupiny tzv. "plackovitých plochých zliatkov“, ktoré sa vyznačujú nepravidelným oválnym tvarom. Formy zliatkov nie sú náhodné a ich analógie nachádzame na mnohých lokalitách v strednej Európe.

\section{Fragmenty}

Do kategórie fragmentov radíme bronzovú špirálku z tenkého a husto navinutého drôtu (tab. III: 15). Pravdepodobne bola súčastou prsteňa, príp. častou špirálky z náhrdelníka, či náramku. Zlomok nie je chronologicky citlivý, nakol'ko sa tento tvar špirálky vyskytuje počas celého obdobia od lengyelskej kultúry až po dobu halštatskú. Motív špirály vo všeobecnosti nachádzame $\mathrm{v}$ podobe okuliarovitých záveskov, ale aj ako ornamentiku na keramike (Chroporský 1960, 70).

Pravdepodobne z terčovitého závesku pochádza fragment kruhovitého predmetu s viditel'nými kruhovými žliabkami (tab. III: 16). Podobnost možno nájst' na bronzových liatych príveskoch, ktoré boli objavené v Nižnej Myšli (Olexa 2003, F6) alebo v Hodejove v depote II/1961 (David 2002, tab. 175). Pôvodne mohol byt' súčastou hlavice ihlice typu Barca, ktoré sú klasifikované do tzv. kosziderských bronzov (Kovács 1975, 304; Novotná 1980, tab. 7). Bez ohladu na interpretáciu fragmentu ako časti ihlice typu Barca, alebo ako časti terčovitého závesku ostáva chronologické zaradenie predmetu rovnaké - artefakt možno zaradit’ do obdobia kosziderského horizontu.

Kuželovitý stočený pliešok $\mathrm{s}$ priemerom $1 \mathrm{~cm}$ (obr. 8: 5) sa nachádzal v objekte 571, konkrétne v jeho západnej časti v hornej žlto-hnedej vrstve (Szabová 2019, 63). Nakolkko ide o fragment, pôvodne mohol patrit k ihlici typu Hülsenkopfnadeln (podla Novotná 1980, tab. 1), príp. môže íst' o tutuli, ktorý je tradične interpretovaný ako súčast' odevu (Kiss 2009, 332).

Viacero fragmentov nie je možné presnejšie charakterizovat' vzhladom na stav ich zachovania (tab. III: 5, 6, 10-12, 14).

\section{KAMENNÁ INDUSTRIA}

Kameň bol aj v počiatkoch strednej doby bronzovej stále dominantnou surovinou využívanouv rámci aktivít súvisiacich s remeselnou činnostou. V Nižnej Myšli to priamo dokladá množstvo objave- ných kamenných nástrojov, resp. štiepanej a ostatnej industrie. Jadrá, polotovary, výrobný odpad, ale aj opotrebované nástroje a ich fragmenty poukazujú na skutočnost', že sa nástroje vyrábali a používali priamo na opevnenom sídlisku.

\section{Štiepaná industria}

Štiepanú industriu (d’alej ŠI) predstavuje 490 analyzovaných exemplárov, pričom dominantnou surovinou bol obsidián, distribuovaný z oblasti Zemplínskych vrchov. Exempláre z obsidiánu pochádzajú takmer výlučne zo zdrojov medzi Brestovom, Cejkovom a Zemplínom, avšak ojedinele sa vyskytli aj artefakty vyrobené z obsidiánu typu Viničky (Přrichystal/Škrdla 2014, 216, 224). Najbližšie zdroje obsidiánu sa od Nižnej Myšle nachádzajú vzdušnou čiarou približne $30 \mathrm{~km}$. Na základe rozdelenia proveniencie kamenných artefaktov podla D. Hovorku tak možno hovorit’ o surovinách, polotovaroch, či hotových výrobkoch, ktoré boli na miesto nálezu transportované zo vzdialenosti jedného pochodu (Hovorka 2008, 99). Je však nutné vziat do úvahy, že prekonanie Slanských vrchov mohlo značne predĺžit čas za ktorý boli obsidiánové artefakty transportované na požadované miesto. Preferovanie obsidiánu ako materiálu pri výrobe štiepaných kamenných nástrojov tak mohlo byt’ okrem relatívne blízkych zdrojov podmienené najmä vhodnými vlastnostami - dobrou štiepatelnostou a výnimočnou ostrostou (Janšák 1935, 77). Ďalší významný zdroj kamennej suroviny predstavoval limnosilicit (vrátane jeho variety Banské). Jeho zdroje sa nachádzajú v oblasti Slanských vrchov, ide teda o lokálny zdroj suroviny, preferovaný najmä pre dobrú dostupnosṫ' (Přichystal 2009, obr. 69). Ostatné kamenné suroviny predstavujú len nepatrný podiel v rámci kamenného materiálu využivaného na výrobu ŠI (obr. 9). Predstavujú však dôležité poznatky o kontaktoch s regiónmi, kde sa tieto suroviny vyskytujú, t. j. oblast Zemplína (ondavský rohovec), Šariša (rádiolarit podobný typu Vršatské Podhradie vyskytujúci sa v oblasti medzi Kyjovom a Kamenicou) alebo južné a stredné Pol'sko (silicity glacigénnych sedimentov a silicity krakovsko-čenstochovskej jury, varieta Gojść). Súbor ŠI pozostával predovšetkým z úštepov a odštepov (50\%), čepele tvorili $26 \%$ a ostatné typy zahrňujúce konkrétne nástroje (škrabadlá, vrtáky, rydlá, vruby, trapéz) a militáriá (hroty šípov) tvorili $15 \%$, zatial čo jadrá $9 \%$. Využívaná bola najmä úštepová a čepelová industria. Konkrétne typy nástrojov, ktoré už boli podrobnejšie analyzované $\mathrm{v}$ inej práci, predstavovali z hladiska početnosti súboru len malú zložku (obr. 10; Olšav 2019). 


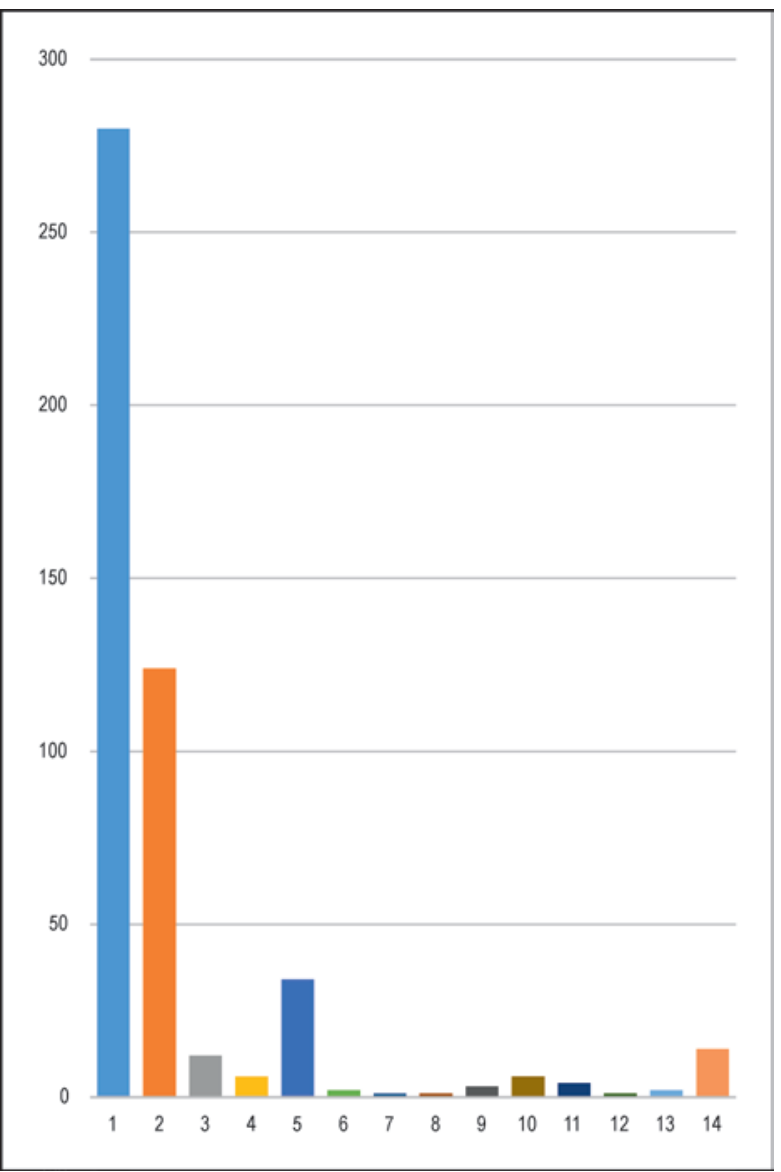

Obr. 9. Zastúpenie kamennej suroviny štiepanej industrie na opevnenom sídlisku II v Nižnej Myšli. 1 - obsidián; 2 - limnosilicit; 3 - limnosilicit typu banské; 4 - ondavský rohovec; 5 -rádiolarit; 6 - silicit krakovsko-čenstochovskej jury, varieta Gojść; 7 - silicit krakovsko-čenstochovskej jury; 8 - silicit; 9 - kremeň; 10 - rohovec; 11 - eratické silicity glacigénnych sedimentov; 12 - silicifikovaný prachovec; 13 - opál; 14 - neurčené.

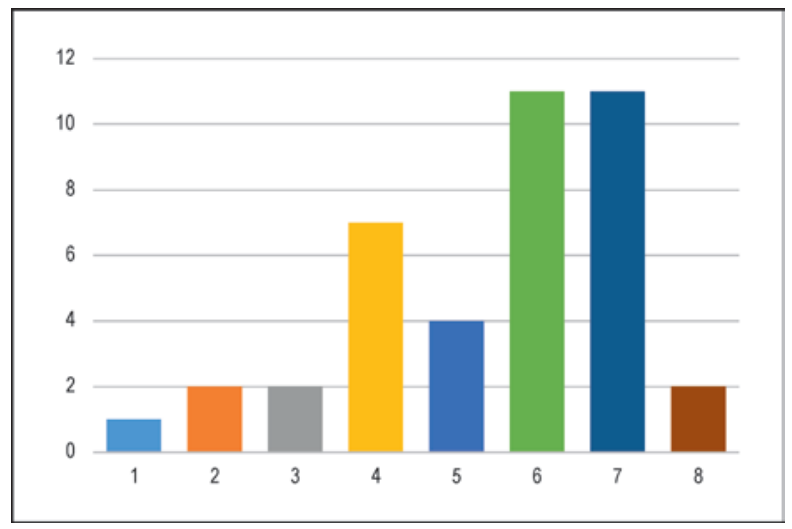

Obr. 10. Typologické zastúpenie nástrojov štiepanej industrie na opevnenom sídlisku II v Nižnej Myšli. 1 - silicitový zakrivený nôž; 2 - kosákové čepiel'ky; 3 - pílky; 4 - škrabadlá a mikroškrabadlá; 5 - vrtáky; 6 - vruby; 7 - rydlá; 8 - hroty.
Retuš možno pozorovat na 30,2 \% exemplároch ŠI. Vel'mi podobný podiel retušovaných nástrojov pochádza z opevnenej osady v Spišskom Štvrtku, kde retuš dosahovala 33,3 \% (Oravkinová/Vladár 2021, 193). Kvalita a zastúpenie ŠI v Spišskom Štvrtku poukazuje na degradáciu ŠI v dôsledku postupného nahrádzania kameňa kovom (Oravkinová/Hromadová/Vlačiky 2017, 59). Analýzou súboru ŠI z Nižnej Myšle sme dospeli k rovnakému záveru. Z celkového súboru tvoril výrobný odpad asi $37 \%$ a spolu s vysokým počtom jadier $(48 \mathrm{ks})$ priamo poukazuje na lokálnu výrobu ŠI na opevnenom sídlisku II (tab. IV: 1-7). Jadrá, ktoré sú zvyškom po opracovaní kamennej suroviny za účelom tvorby úštepov umožňujú sledovat priestory $\mathrm{v}$ ktorých mohla prebiehat' produkcia SI. Z tohto hladiska sú dominantné dva areály. Prvý sa nachádzal vo východnej časti v tesnej blízkosti fortifikácie a brány. Druhý areál sa viaže na severovýchodnú čast opevnenej osady II, taktiež v blízkosti fortifikácie (a severnej brány?). Jadrá sa v prevažnej miere nachádzali v domoch, čo poukazuje na domácu produkciu ŠI (plán 2). Ide najmä o domy - objekty $527,416,530$ a 536 . Dve jadrá sa našli aj v sonde $54 \mathrm{v}$ juhovýchodnej časti opevneného sídliska $\mathrm{v}$ okolí obytného objektu. Ked’že sa $\mathrm{v}$ tejto časti iná kamenná industria nenachádzala, v plánoch zobrazujeme len čast' lokality s jej výskytom. Početnejšie sa jadrá koncentrovali aj v objekte 519, spájaného s metalurgickou činnostou, ktorý sa nachádza v bezprostrednej blízkosti domov 530 a 536 (plán 2). Je preto možné uvažovat’ o špecializovanej činnosti v daných objektoch (najmä v objektoch 416, 530, 536 a 519). Pri pohlade na celkový výskyt ŠI na opevnenom sídlisku II sa situácia výrazne nemení a podporuje uvedenú hypotézu (plán 3). Zmena však nastáva pri väčšom množstve ŠI vo východnej časti priekopy v blízkosti brány, ale tiež v severovýchodnej časti opevneného sídliska II (plán 3). Celkové množstvo ŠI a jej umiestnenie v priestore poukazuje na areály, v ktorých sa vykonávali činnosti spojené so ŠI, alebo na miesta, kde boli deponované za iným účelom, napr. odhodenie po opotrebovaní. Fragmenty nástrojov sa vyskytovali v domoch kde bola ŠI produkovaná, ale tiež v jamách v blízkosti týchto domov. Množstvo fragmentov ŠI sa nachádzalo aj v priekope (objekt 408), zemníkoch (objekt 177, ten bol však využívaný najmä v čase trvania osady I) a taktiež v objekte 519. Vyrábanie, využívanie a deponovanie opotrebovaných nástrojov tak často prebiehalo v rovnakých areáloch. Do zásypu priekopy (objekt 408) preto mohol byt' deponovaný odpad z nedalekého domu (objekt 416), nakol'ko v objektoch v blízkosti tohto domu sa ŠI nenachádzala, zatial' čo počet ŠI v dome (objekte 416) bol značne vysoký. 


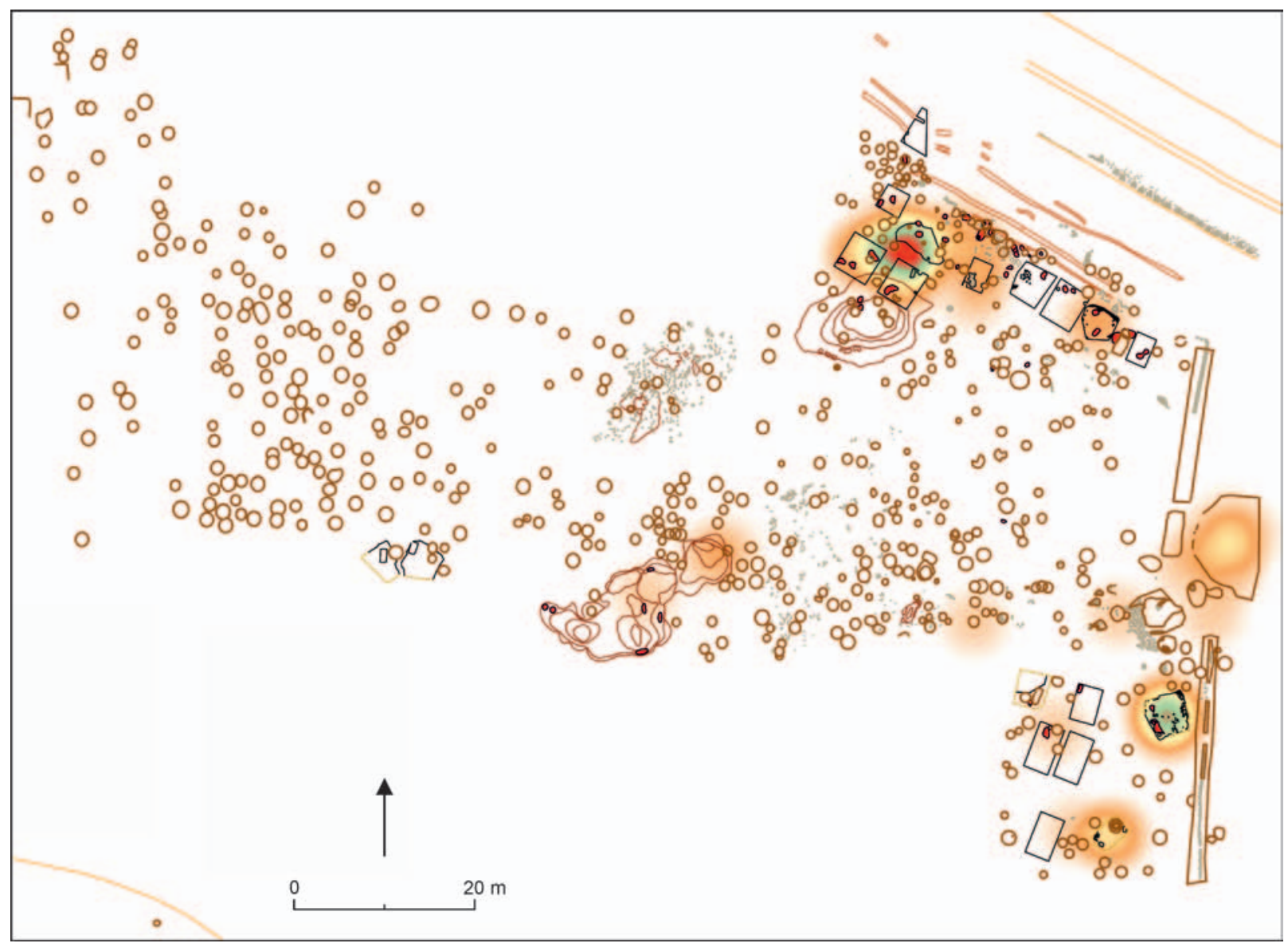

Plán 2. Nižná Myšla-Várhegy. Priestorová distribúcia štiepanej industrie - jadrá.

Metalurgický objekt 519 mohol taktiež plnit’ podobnú sekundárnu funkciu v okolí domov 530 a 536. Po primárnej metalurgickej činnosti bol totiž neskôr využitý ako odpadová jama, hoci nie je vylúčené, že v ňom okrem metalurgie prebiehali aj iné remeselné aktivity súvisiace so ŠI. Distribučný model poukazuje na existenciu výrobných okrskov v severovýchodnej a východnej časti opevneného sídliska, zároveň tak na bežnú výrobu ŠI a jej využívanie v domácnostiach. Podobný model sa nachádzal taktiež na opevnenom sídlisku OFKK v Spišskom Štvrtku (OravkinoválVladár 2021, 193).

V rámci ŠI stojí za zmienku aj výroba hrotov šípov (tab. IV: 8-15). Na základe lokalizovania polotovarov hrotov šípov (tab. IV: 16, 17) sa ich výroba odohrávala len $\mathrm{v}$ domoch $\mathrm{v}$ ktorých je preukázaná špecializovaná výroba ŠI (objekty 416, 530, 427). Po jednom exempláre sa polotovary hrotov šípov nachádzali aj v objekte 408 (priekopa) a objekte 177 (zemník). Táto skutočnosț podporuje doterajšie zistenia o špecializovanej výrobe ŠI v konkrétnych areáloch.

Možno tiež spomenút dve čepele s tzv. kosákovým leskom, ktoré sa podarilo identifikovat' na opevnenom sídlisku II. Je pravdepodobné, že počet exemplárov s kosákovým leskom mohol byt vyšší, avšak pri výrobe ŠI bol dominantnou surovinou najmä obsidián. Ten však nemožno spolahlivo rozoznat', kedže na obsidiáne sa kosákový lesk nezachováva. Jeden z exemplárov s kosákovým leskom pochádza zo zemníka (objekt 177), ktorý časovo spadá do obdobia trvania opevneného sídliska I. Druhý exemplár pochádza z domu - objektu 536, teda z objektu s vysokým počtom ŠI. Ked’že nejde o fragment je možné, že v tomto priestore nebola ŠI len vyrábaná, ale že ju v rámci inej pracovnej činnosti využíval aj priamo jej výrobca ako súčast kosákového nástroja.

\section{Ostatné kamenne predmety}

Súbor nástrojov a predmetov z kameňa, ktoré nesúvisia so ŠI zastupuje 378 analyzovaných exemplárov. Radia sa k nim špecializované nástroje upravené do požadovaného tvaru (napr. sekeromlaty, sekery, kamenné zahnuté nože, brúsiky), nástroje čiastočne upravené alebo vôbec neupravené - vy- 


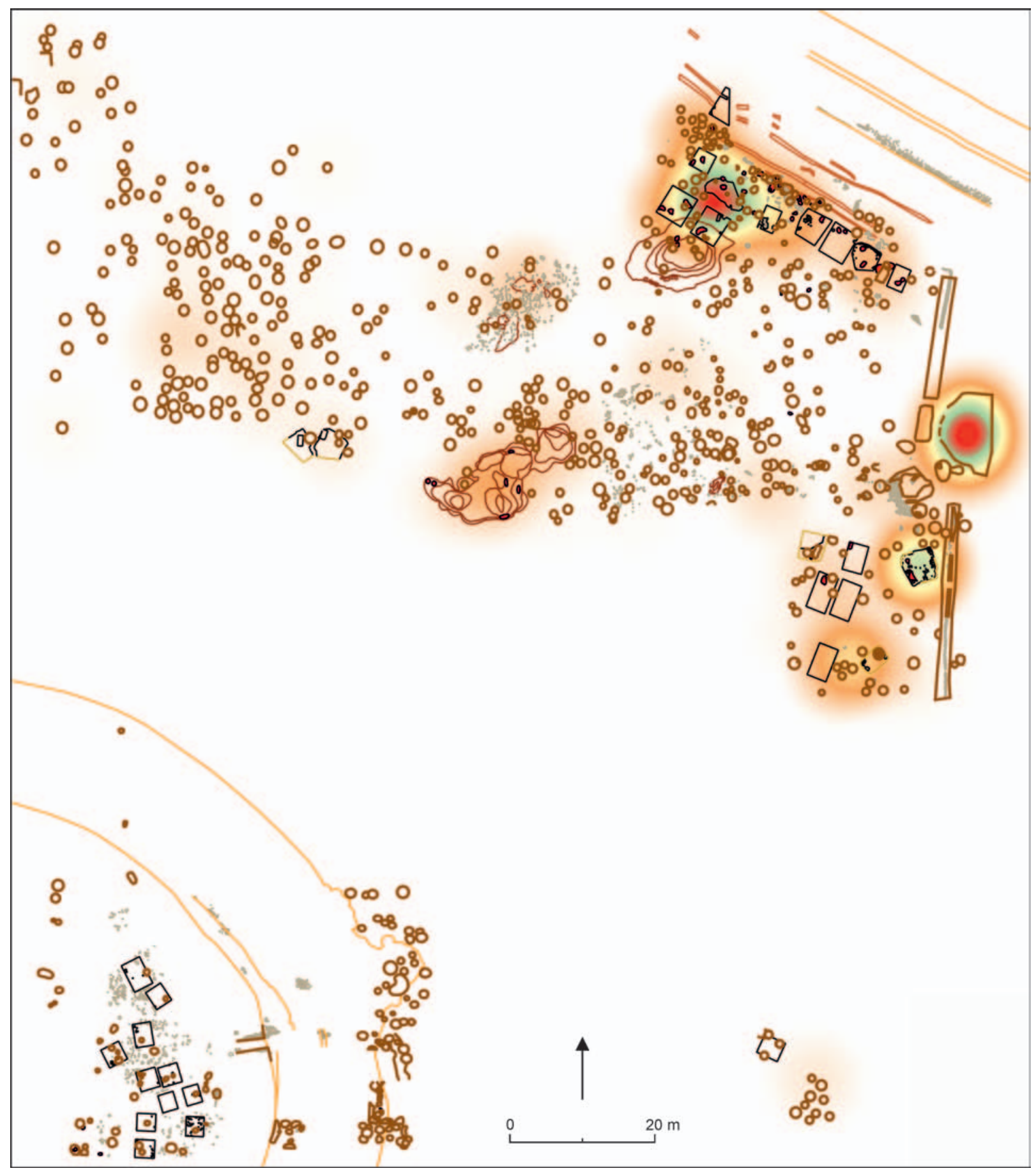

Plán 3. Nižná Myšla-Várhegy. Priestorová distribúcia štiepanej industrie - celý súbor.

užívajúce prirodzený tvar kameňa (napr. viaceré nástroje na brúsenie, hladenie a leštenie, nástroje na mletie a drvenie) a predmety s nejasnou funkciou. Boli vyrábané z lokálnych materiálov (napr. andezit, kremeň), alebo zo surovín, ktoré sa vyskytujú v oblastiach vzdialených aj desiatky kilometrov (pieskovec, bridlica, atd'; Olšav 2019).

Pri zameraní sa na konkrétne (typologicky priamo určitel’né) nástroje, ale tiež na celkové množstvo ostatnej industrie v priestore opevneného sídliska II je možné sledovat’ pracovné aktivity koncentrujúce sa v konkrétnych areáloch (plán 4). Z hl'adiska celkového množstva ostatných kamenných predmetov sa najväčšia koncentrácia nachádzala v severovýchodnej časti opevneného sídliska II, predovšetkým v objekte 519 a v jeho okolí a v dome 444. Ďalšie výraznejšie koncentrácie ostatných kamenných nástrojov a predmetov sa nachádzali vo východnej 


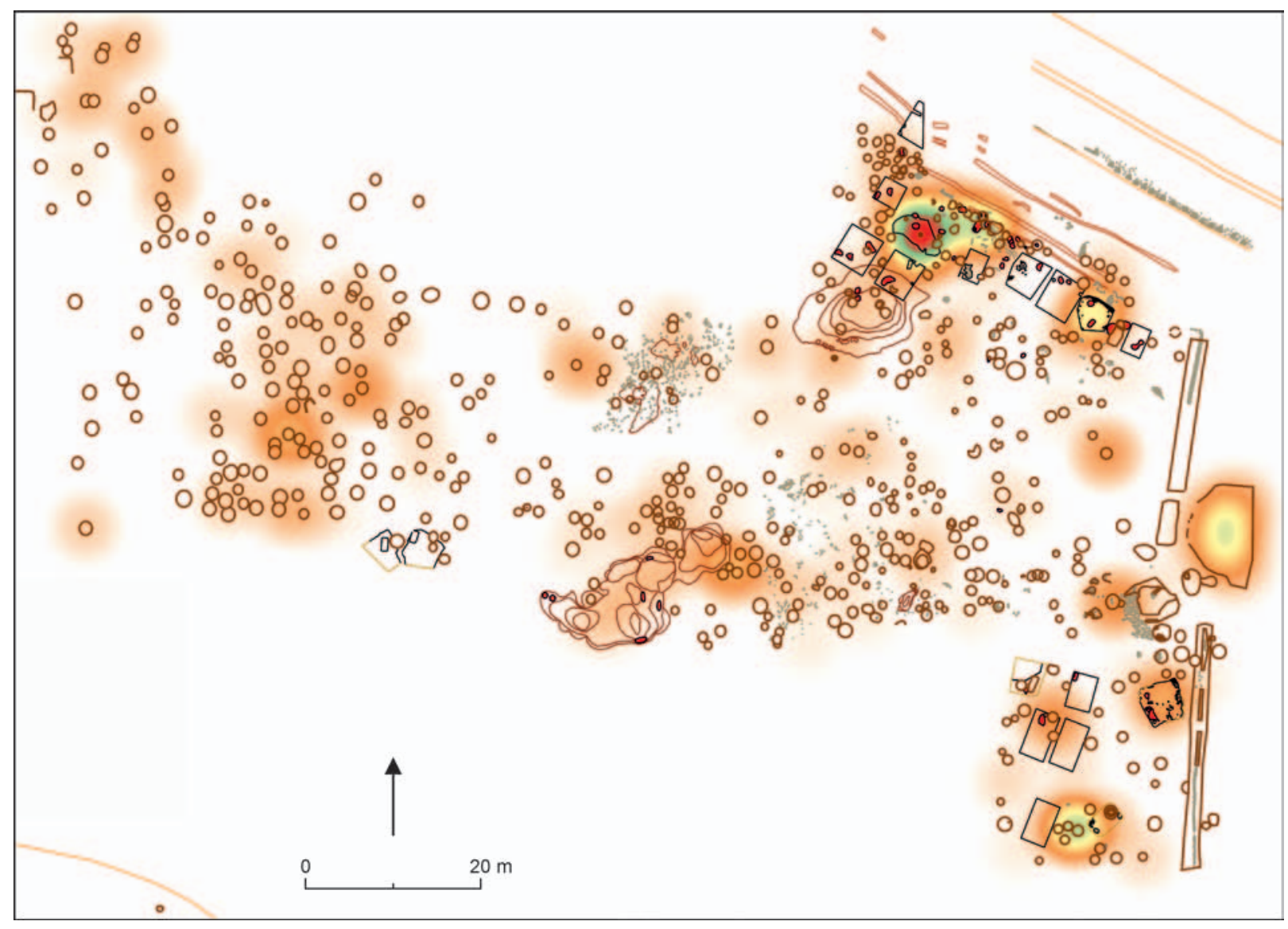

Plán 4. Nižná Myšl’a-Várhegy. Priestorová distribúcia ostatnej kamennej industrie.

časti sídliska, v dome - objekte 427, v objektoch v jeho blízkosti a medzi domami 427 a 467 (plán 4). Ďalšiu koncentráciu možno rozoznał aj v dome 416 a najmä v ned’alekej priekope (objekt 408).

\section{Úderové nástroje $s$ upevnením do násady}

Úderové nástroje $\mathrm{s}$ upevnením do násady predstavovali sekeromlaty a sekery. Sekeromlaty sa na opevnenom sídlisku II nachádzali výlučne vo fragmentoch (tab. V: 1-8). Ich aktuálny počet je 13 kusov, pričom evidujeme aj dva polotovary. Sekery zastupovalo devät exemplárov a $\mathrm{z}$ toho dva vo fragmentárnom stave (tab. V: 9, 11-14). Identifikovaný bol tiež fragment dláta (tab. V: 10). Polotovary a fragmenty týchto nástrojov so stopami po využívaní na funkčných plochách (depresie) poukazujú na výrobu a používanie týchto nástrojov priamo na lokalite. Nachádzali sa ako solitérne kusy, roztrúsené po celej preskúmanej ploche sídliska. Ich väčšia koncentrácia sa nachádzala len v severovýchodnej časti sídliska (plán 5). Úderové nástroje bez upevnenia do násady (najmä vo funkcii kladiva) zastupovalo 15 kusov, pričom dva sa nachádzali v domoch (objekty 427 a 536), štyri v priekope (objekt 408) a zvyšok v jamách (objekty $387,388,434,448,519$ a 565) a kultúrnej vrstve. Opät sa našli na miestach, kde bola identifikovaná aj d’alšia výrobná činnost' súvisiaca s kamennou industriou. Fragmenty sekeromlatov poukazujú na ich využívanie priamo na opevnenom sídlisku. Väčšina analogických nálezov sa nachádza tak isto vo fragmentárnom stave aj na d’alších opevnených či tellových sídliskách OFKK, ako napr. na tellovom sídlisku Ároktő-Dongóhalom (Fischl 2006, 200), či na opevnenom sídlisku v Spišskom Štvrtku (Oravkinová 2018, 184). Zaujímavým nálezom je neolitický kopytovitý klin z metamorfovanej bridlice (tab. VI: 15). Tento typ nástroja sa ojedinele vyskytuje aj na sídliskách z doby bronzovej. Dva analogické predmety sa našli $v$ kontexte osady OFKK vo Füzesabony-Öreg-Dombe. Ich význam je interpretovaný $v$ symbolickej rovine a mohli byt využívané pri ceremoniálnych aktivitách (Horváth a i. 2015, 56). Ďalšou možnostou je, že mohli byt vd’aka svojmu dokonale hladkému vybrúseniu využité ako tzv. skúšobné kamene (touchstones), ktoré 


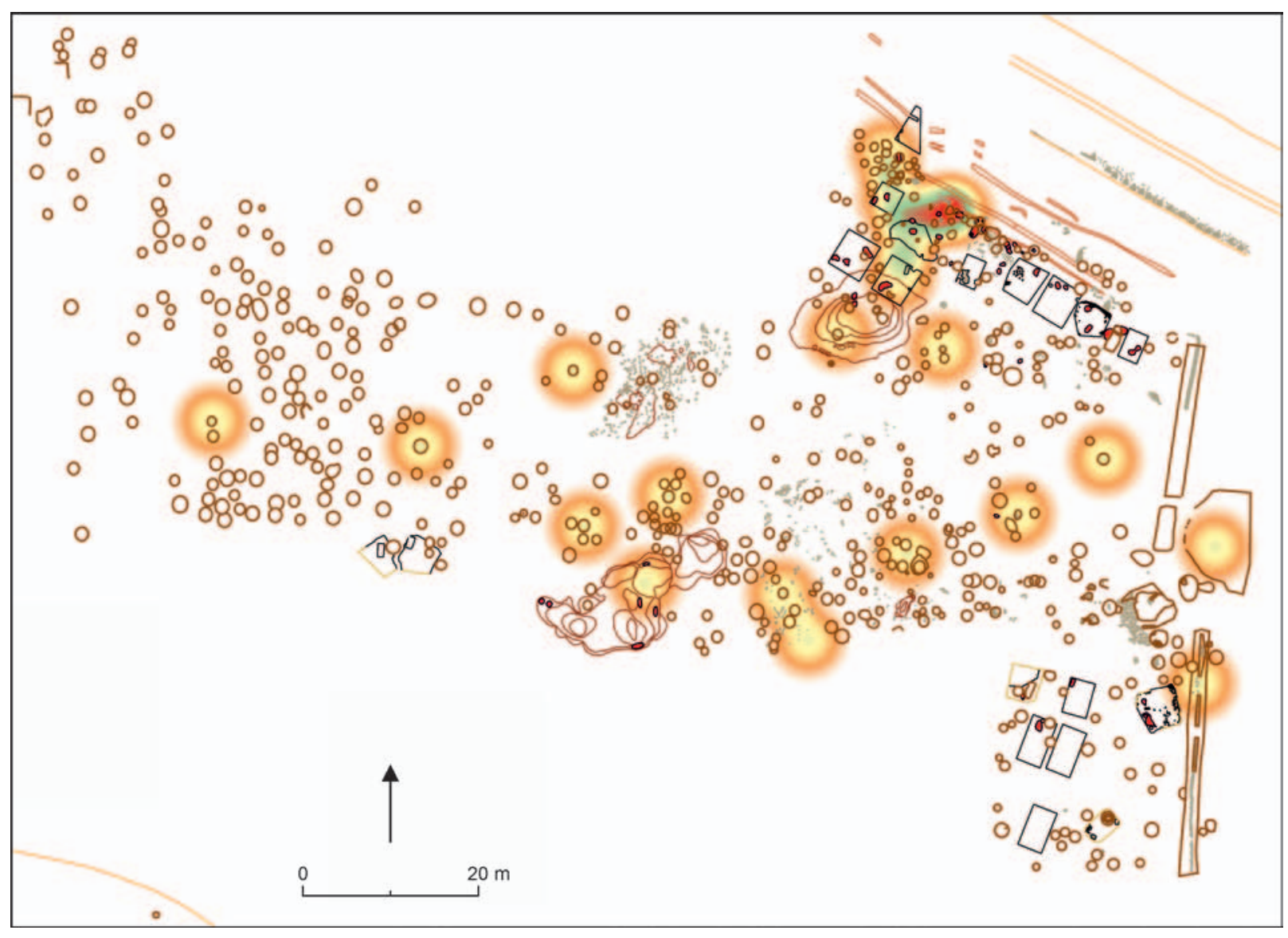

Plán 5. Nižná Myšla-Várhegy. Priestorová distribúcia kamenných sekier a sekeromlatov.

slúžili na testovanie kvality kovu, ako potvrdila analýza dvoch druhotne využitých kopytovitých klinov z Prahy (Ježek 2017, 49).

\section{Nástroje na brúsenie, hladenie a leštenie}

Špecifickým nástrojom sú brúsiky, ktorých bolo identifikovaných 18 exemplárov (tab. VII: 1-11). Do kategórie brúsikov nie sú zarátané všetky nástroje na brúsenie, hladenie a leštenie, ale len špecializované nástroje s typickým tvarom. Mnoho exemplárov predbežne identifikovaných ako nástroje na brúsenie, hladenie a leštenie nie je možné jasne typizovat', ked’že často bola využívaná príhodná morfológia kameňa a v niektorých prípadoch boli pre tento účel sekundárne využivané fragmenty iných kamenných nástrojov. Rozdiel pozorujeme tiež v spôsobe ich využívania. Spôsoby využívania môžeme rozdelit na aktívne (napr. samotné brúsiky) a pasívne (napr. pieskovcové platne s aspoň jednou hladkou stranou; Oravkinová 2018, 184, 187). Pre overenie týchto predpokladov je však nutné podrobit vybrané exempláre trasológii. Stojí za zmienku, že väčšie koncentrácie nálezov sa nachádzali prevažne v severovýchodnej časti sídliska v okolí metalurgického objektu 519, pril'ahlom dome 536, sújamí s množstvom pyrotechnologických zariadení a v dome 444. Dalšie väčšie koncentrácie nálezov (aj ked' menej výrazné v porovnaní so severovýchodnou častou sídliska) sa nachádzali opät’ $\mathrm{v}$ domoch, $\mathrm{v}$ ktorých prebiehala špecializovaná výroba, teda $\mathrm{v}$ dome 416 a v jeho prilahlých objektoch, v objekte 387 nachádzajúcom sa v bezprostrednej blízkosti brány (objekt 400) a v objektoch v okolí domu 427. Vo väčšom množstve sa nachádzali v priekope (objekt 408) a v zemníkoch (objekty 177 a 255; plán 6). Aktuálny súbor týchto typov nástrojov tvorí 99 exemplárov, z toho 52 aktívnych, 43 pasívnych (tab. VII: 12,13) a štyri neurčené nástroje. Údaje sa však po trasologogickej analýze môžu mierne pozmenit. Na niektorých pasívnych nástrojoch boli prítomné žliabky, ktoré dokladajú brúsenie dlhých tenkých predmetov pozdížnou abrazívou alebo ostrenie či reparáciu funkčných hrán (Oravkinová 2018, 187). V prípade niektorých brúsikov nevylučujeme, že boli využívané ako tzv. skúšobné kamene na zistovanie kvality kovu (Ježek 2017, 97 nn.). 


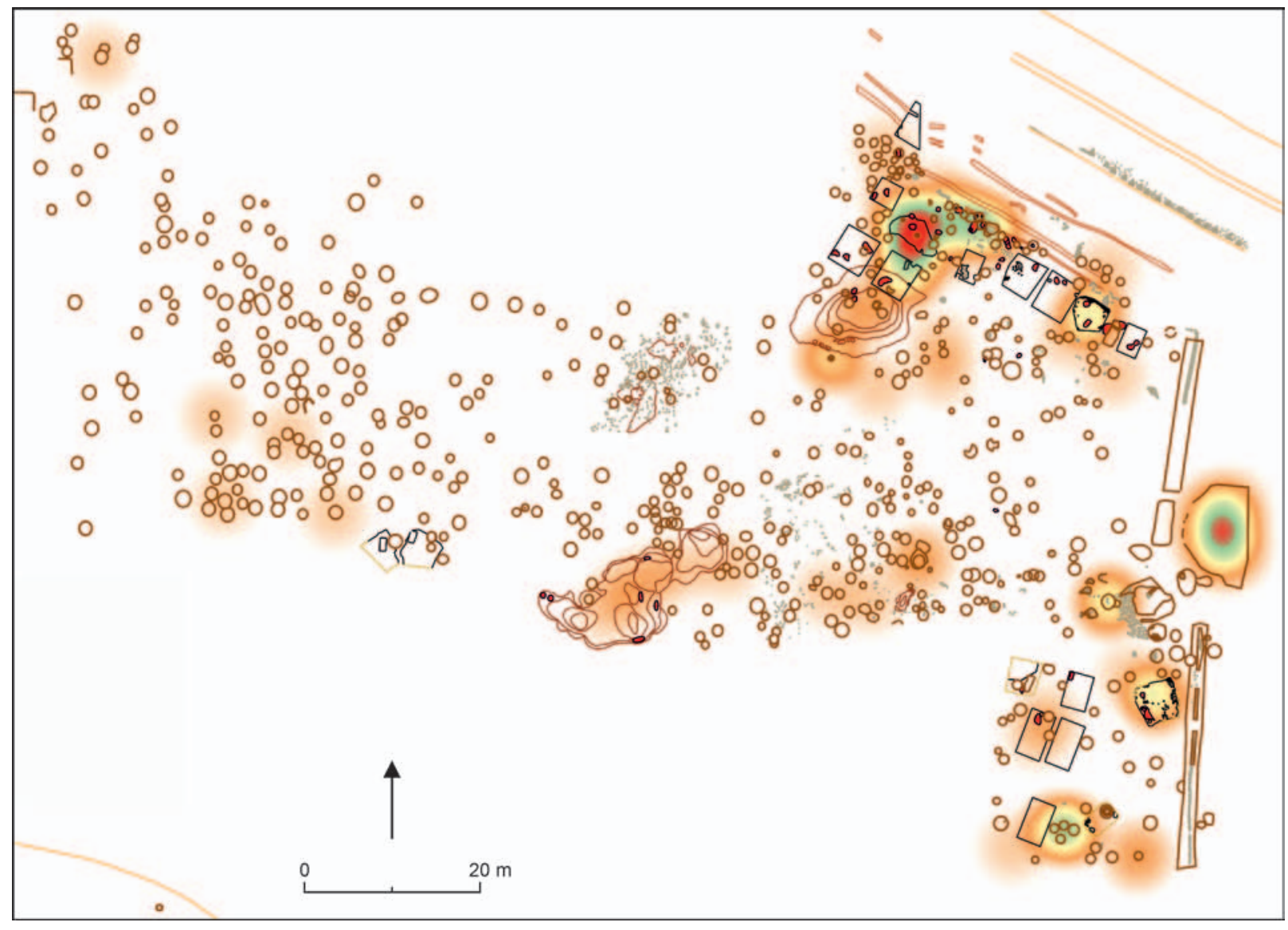

Plán 6. Nižná Myšla-Várhegy. Priestorová distribúcia kamenných nástrojov na brúsenie, hladenie a leštenie.

\section{Nástroje na mletie a drvenie}

Nakol'ko neboli analyzované všetky exempláre zrnotierok, zamerali sme sa na sledovanie drvidiel (34 kusov; tab. VI: 16-19). Aj v tomto prípade sa viac-menej opakuje model ako vo väčšine predchádzajúcich prípadoch s koncentráciou v špecifických remeselných areáloch. Najvyššiu koncentráciu sme zistili v dome 444, kde sa však nachádzali drvidlá skôr menších rozmerov (plán 7). Spolu s nimi sa $\mathrm{v}$ tomto objekte nachádzalo vel'ké množstvo neopracovaných zvieracích kostí, ale tiež ŠI a ostatná kamenná industria. Za zmienku stoja dva objavené kamenné hroty šípov z priestoru domu 444. Jednoznačné stanovisko $\mathrm{k}$ interpretácii tohto objektu bude možné až po prebiehajúcej analýze objaveného súboru zvieracích kostí. Predbežne sa však môžeme domnievat', že sa tu odohrávali aktivity spájané so spracovaním usmrtených zvierat (napr. bitúnok, spracovanie kože či kostí). Menší kamenný mažiar z objektu 388 (na kompletne zachovanej strane ma dížku 104 mm) s vyhlbeným okrúhlym žliabkom približne v strede predmetu poukazuje aj na využitie drvidiel menších rozmerov.

\section{Kamenné formy na odlievanie farebných kovov}

Kamenné kadluby svojim zastúpením (46 identifikovaných exemplárov) predstavujú významný doklad o metalurgickej činnosti priamo na opevnenom sídlisku II a dovolujú ho považovat za regionálne centrum produkcie bronzových predmetov. Kamenné kadluby sa sporadicky nachádzali v rôznych častiach sídliska (plán 8). To môže podobne ako na súčasnom opevnenom sídlisku v Spišskom Štvrtku poukazovat na špecializovanú metalurgickú činnost’ a súbežnú domácku výrobu (Oravkinová/Vladár 2021, 195). Koncentrácia kamenných kadlubov v počte devät kusov (spolu s nálezmi téglikov, bronzových zliatkov a dvoch pyrotechnologických zariadení) v objekte 519 dokladá špecializovanú metalurgickú činnost', resp. prítomnost dielne priamo v severovýchodnej časti opevneného sídliska II (plán 8; Szabová 2017, 25). V tomto objekte sa nachádzalo tiež väčšie množstvo nástrojov na brúsenie, hladenie a leštenie, čo môže poukazovat taktiež na aktivity súvisiace s finálnymi úpravami kovových predmetov. Za- 


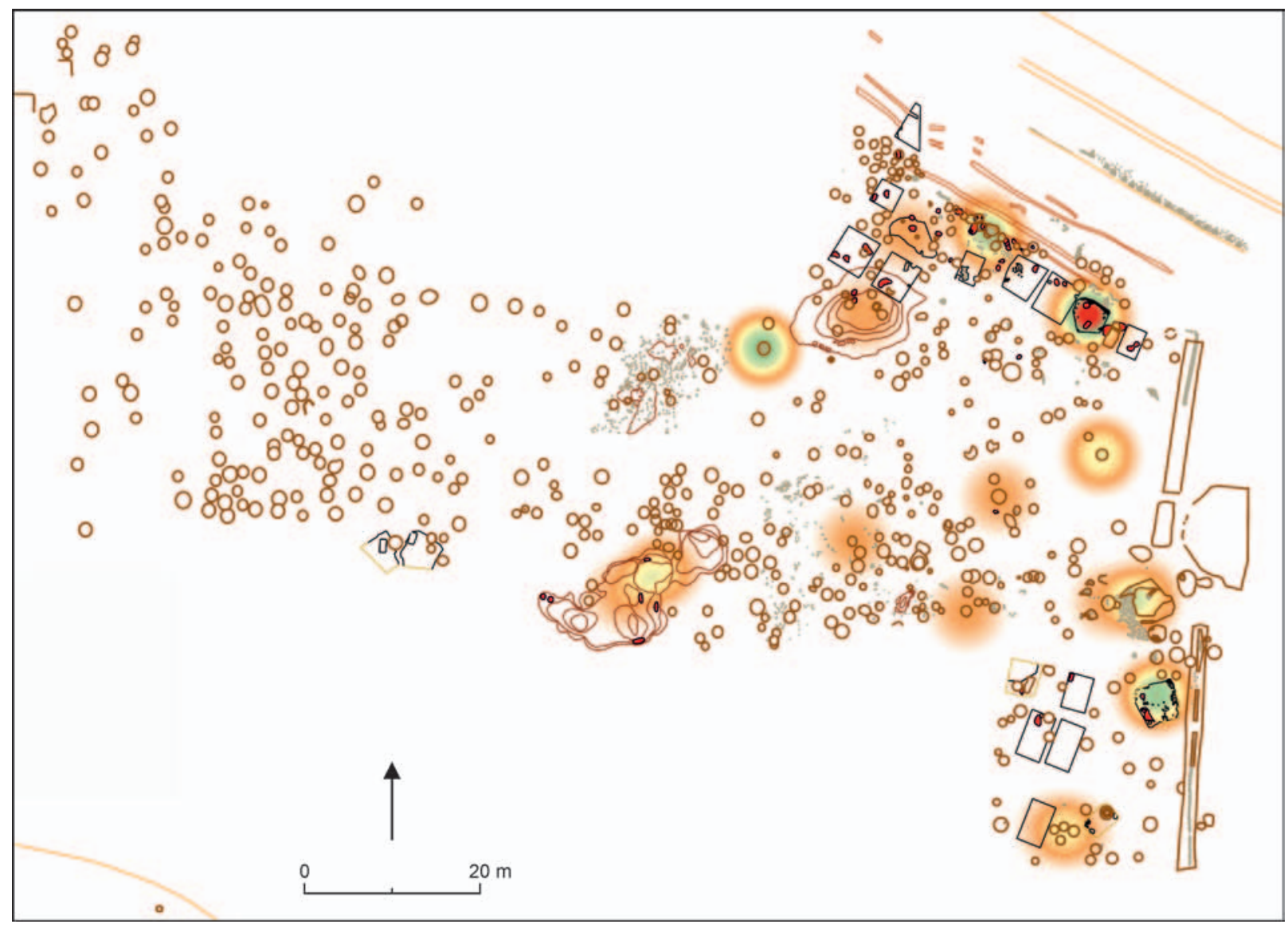

Plán 7. Nižná Myšla-Várhegy. Priestorová distribúcia drvidiel.

ujímavým nálezom je pieskovcový zahnutý nôž $\mathrm{s}$ upravenou chrbtovou častou a viacnásobnými trojuholníkovými výsekmi (tab. VIII: 9). Takto sekundárne upravený nástroj mal pravdepodobne funkciu brúsika. V objekte sa vyskytli aj d’alšie štyri fragmenty kamenných zahnutých nožov, ktoré mohli byt pre vhodný tvar sekundárne využité rovnakým spôsobom. Konkrétne typy a exempláre kadlubov sú opísané v predchádzajúcich častiach tohto príspevku.

\section{Kamenné zahnuté nože}

Ďalším typom nástroja v Nižnej Myšli boli kamenné zahnuté nože (nemecky Krummesser), ktoré pravdepodobne plnili funkciu kamenných kosákov. Významný je predovšetkým exemplár zahnutého noža (obr. 11), ktorý je vyrobený zo silicitu krakovsko-čenstochovskej jury typu Gojść, ktorého ložiská sa nachádzajú na území Pol'ska v najsevernejšej časti Krakovsko-čenstochovskej vrchoviny (Přichystal 2009, 94). Z rovnakej suroviny bola taktiež vytvorená kosáková čepel’ s prítomným kosákovým leskom

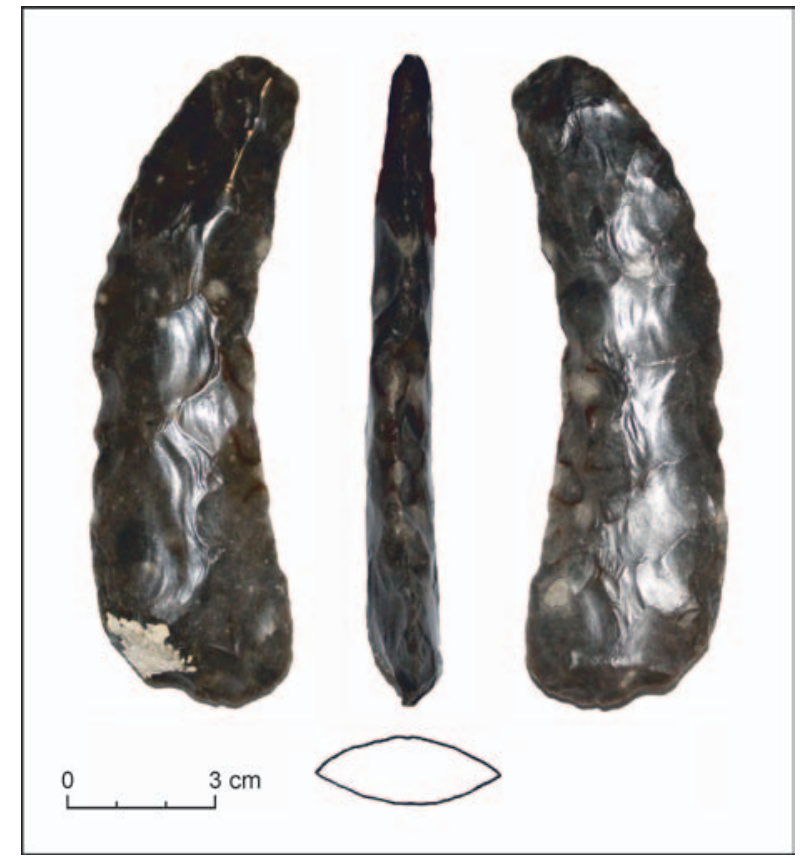

Obr. 11. Nižná Myšla-Várhegy. Silicitový zahnutý nôž (Krummesser) z narušeného kontextu na opevnenom sídlisku II. 


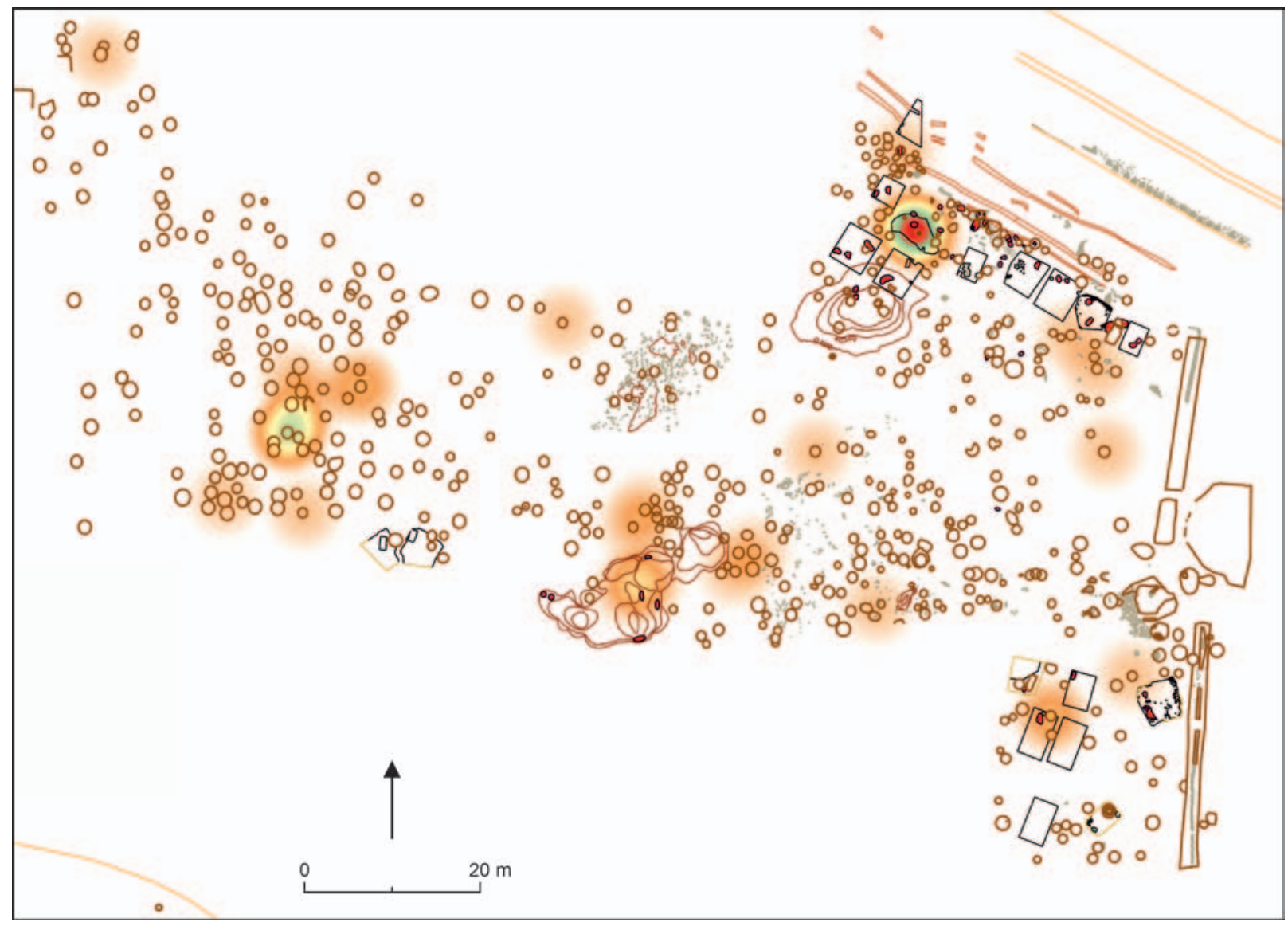

Plán 8. Nižná Myšla-Várhegy. Priestorová distribúcia kamenných kadlubov.

(pozri vyššie). Nástroje boli pravdepodobne importované z prostredia výskytu uvedeného silicitu.

Silicitový zahnutý nôž z Nižnej Myšle sa našiel ako solitérny nález v narušenej vrstve. Je preto otázne, či išlo o dočasné uloženie, symbolický akt, alebo súčast̉ inventáru domu (Olšav 2019, 28). Rozoraná vrstva s väčším množstvom kameňov však poukazovala na možný pozostatok domu. Z hladiska početnosti boli významné nesilicitové kamenné zahnuté nože (tab. VIII). Až 35 exemplárov kosákovitých nástrojov tohto typu, $\mathrm{z}$ ktorých väčšina sa nachádzala vo fragmentárom stave, predstavuje jednoznačne najvyšší počet objavených kamenných zahnutých nožov na jednej lokalite. Boli vyrábané z rôznych kamenných surovín ako napr. pieskovec, jemnozrnný pieskovec, prachovec, bridlica a andezit (Olšav 2019, 45). Nesilicitové kamenné zahnuté nože sa na území dnešného Pol'ska a najmä v oblasti Malopol'ska, kde je ich výskyt najvyšší, rozšírili spoločne s otomanskou a trzcinieckou kultúrou (Libera a $i$. 2015, 69). Vo všeobecnosti sa v susediacich krajinách vyskytovali najviac v Malopol'sku, kde sa do roku 2015 evidovalo 26 nálezov z 21 lokalít (Libera a $i$. 2015, 69). Najpočetnejšie zastúpenie v počte štyroch kusov je zatial' evidované na opevnenom sídlisku v Trzcinici. Na opevnených sídliskách na Slovensku doposial' zistené neboli (Valde-Nowak/Gancarski 1999, obr. 2: 1, 5; 9:4, 10). Expanzia kamenných zahnutých nožov sa viaže na komplex Schneckenberg-Glina III, odkial' sa neskôr d’alej šírili dvoma smermi: severovýchodným, prostredníctvom kultúry Monteoru a Costișa a severozápadným, prostredníctvom OFKK (Kopacz 2001, 97, 98; 2011, 74). Treba však upozornit na skutočnost', že kamenné zahnuté nože sa objavujú už v hroboch mierzanowickej kultúry (napr. Machnik 1972, tab. I: 30; VI: 17), pričom ako vyplýva z nasledujúcich riadkov, slovenská enkláva OFKK nebola priamym prostredníkom tohto typu nástroja medzi Karpatskou kotlinou a územím dnešného Pol'ska. Na Slovensku boli doteraz nálezy tohto typu výnimkou. Reprezentujú ich ojedinelé nálezy pochádzajúce $z$ Vel'kej Lomnice, z polohy Ku Cintorínu, kde sa našli dva fragmenty kamenných zahnutých nožov vyrobené z pieskovca a sú chronologicky zaradené do OFKK (Kučerová 2012, 138) alebo v Poprade-Matejovciach, kde bol objavený pieskovcový zahnutý nôž datovaný do záverečnej fázy OFKK (Soják 2003, 472). Zatial' čo 


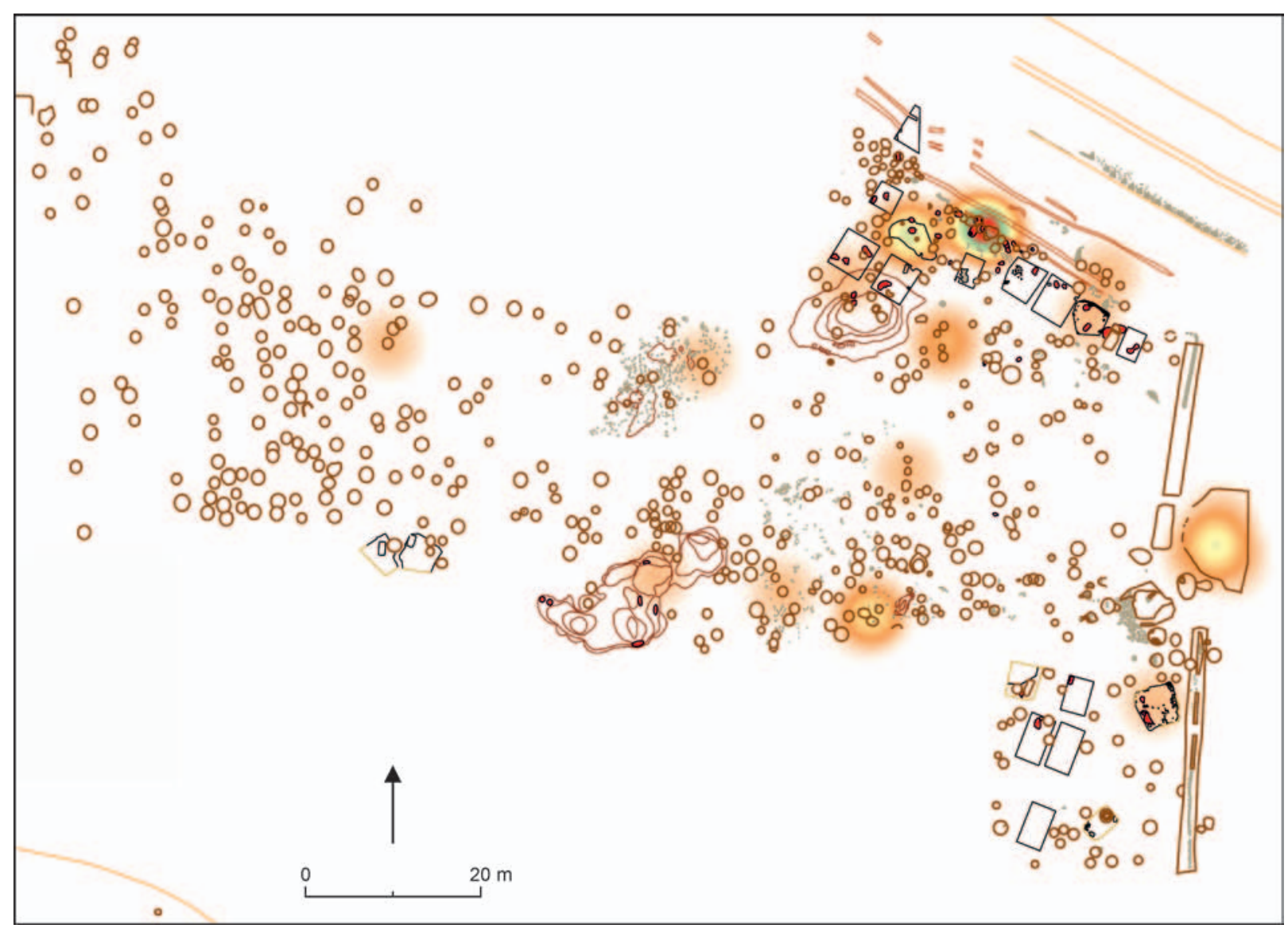

Plán 9. Nižná Myšla-Várhegy. Priestorová distribúcia kamenných zahnutých nožov.

silicitové kamenné zahnuté nože sú na Slovensku výnimkou, pre oblast' Malopol'ska a Volyne je ich výskyt takpovediac príznačný. Opačný prípad mohol nastat' v prípade nesilicitových zahnutých nožov, ktorých je len v Nižnej Myšli viac, než všetkých evidovaných nálezov tohto typu na území Pol'ska dohromady. Na druhej strane je nutné si uvedomit,, že oba typy kamenných zahnutých nožov (silicitové aj nesilicitové) sa objavujú súčasne a ich materiálové prevedenie môže byt' podmienené dostupnostou lokálnych surovín. Prevaha silicitových zahnutých nožov v Malopol'sku a v oblasti Volyne a nesilicitových zahnutých nožov v oblasti Košickej kotliny sa tak javí ako opodstatnená. Zaujímavá je v tomto ohlade absencia kamenných zahnutých nožov v Spišskom Štvrtku (Oravkinová 2018). Na opevnených sídliskách v Košiciach-Barci, Rozhanovciach a dokonca ani na sídlisku I v Nižnej Myšli sa tento typ nástroja nenachádzal. ${ }^{4}$ Sporadické nálezy kamenných zahnutých nožov v prostredí OFKK na severovýchodnom Slovensku sú spájané s územím severne od hrebeňa Karpát (Soják 2003, 471 n.). Vý- skyt kamenných zahnutých nožov len na jednom opevnenom sídlisku v jeho záverečnej fáze, ako aj sporadické nálezy kamenných zahnutých nožov na severe východného Slovenska naznačujú, že sa $\mathrm{k}$ nám tento typ nástroja dostal z územia dnešnej juhovýchodnej časti Pol'ska a to až v záverečnej fáze OFKK. Vysoký počet kamenných zahnutých nožov na opevnenom sídlisku II v Nižnej Myšli poukazuje na výrobnú dielňu alebo na ich domácku produkciu v areáli sídliska, pričom tento druh nástroja možno (najmä z hladiska početnosti) vnímat' ako lokálne špecifikum v prostredí OFKK na Slovensku. $\mathrm{Na}$ území dnešného Rumunska sú početné nálezy nesilicitových (zväčša pieskovcových) zahnutých nožov na sídliskách bežným javom už v kultúrnom komplexe Schneckenberg-Glina III a pretrvávajú až do obdobia OFKK (Frînculeasa/Garvăn/Preda-Bălănică 2019, 127-129). Avšak tento fenomén sa v slovenskej enkláve OFKK prejavil iba v záverečnej fáze OFKK na opevnenom sídlisku II v Nižnej Myšli, pričom dosial chýbajú presvedčivé dôkazy o prenikaní tohto typu nástroja z územia juhovýchodnej časti

4 Za ústnu informáciu dakujem PhDr. D. Gašajovi. 
Karpatskej kotliny na územie dnešného východného Slovenska. Ako pravdepodobnejšia sa v tomto svetle javí možnost', že kamenné zahnuté nože sa rozšírili trasou smerujúcou $z$ oblasti dnešného Rumunska prostredníctvom kultúr Monteoru a Costișa, pozdíž pravých prítokov Tisy a cez územie Ukrajiny do juhovýchodného Pol'ska už v dobe trvania mierzanowickej kultúry a najmä neskôr počas trvania OFKK a trzcinieckeho kultúrneho okruhu (Kopacz 2001, 97, 98; 2011, 74; Libera a i. 2015, 90-94; Makarowicz/Górski/Lysenko 2013, 180-184, 199, obr. 18). Odtialto sa dostávali do prostredia OFKK na Slovensku, na čo poukazuje aj silicitový zahnutý nôž vyrobený zo silicitu krakovsko-čenstochovskej jury typu Gojść z Nižnej Myšle. Túto hypotézu môže nezávisle podporovat aj ojedinelý nález silicitového zahnutého noža, ktorý bol objavený na brehu Zemplínskej šíravy, vyhotovený bol z volynského pazúrika, a ojedinelé nálezy nesilicitových zahnutých nožov na severovýchode Slovenska (Gačková 1999, obr. 25). Predpokladáme, že sa k nám tento typ nástroja dostal „oklukou“ spoza východných Karpát až cez priesmyky na dnešnej slovensko-pol'skej hranici. Nevylučujeme však možnost', že tento obraz je obmedzený aktuálnym stavom bádania a v budúcnosti sa môže, s pribúdajúcimi nálezmi, preukázat' možné prúdenie nesilicitových zahnutých nožov západnou trasou prostredníctvom OFKK (Kopacz 2001, 97, 98; 2011, 74).

Najväčšia koncentrácia týchto nástrojov sa nachádzala v severovýchodnej časti sídliska vo viacnásobnom sújamí (sedem), v priekope (objekt 408; pät), v objekte 519 (štyri) a v sonde 30 - sektore A (tri). Po jednom exemplári sa nachádzali v dome 444 a 416. Fragment z objektu 244 sa nachádzal v blízkosti nálezu silicitového zahnutého noža. Ostatné kamenné zahnuté nože sa nachádzali v objektoch a vrstvách roztrúsené v rôznych častiach sídliska (plán 9). Ked’že drvivá väčšina bola vo fragmentárnom stave je možné, že sa po doslúžení sekundárne využívali ako nástroje na brúsenie, hladenie a leštenie.

\section{Militárie}

Výroba militárií z kameňa sa nevztahuje len na hroty šípov. Na sídlisku v Nižnej Myšli boli identifikované tri tufové gule ( $\mathrm{z}$ toho jedna vo fragmentárnom stave), ktoré poukazujú na eventuálne využívanie aj d’alšej dial'kovej zbrane - praku (obr. 12; Olšav 2019, 5456). Tvarovo a rozmermi analogické početné nálezy hlinených striel do praku poznáme z opevneného sídliska mladšej doby bronzovej z obce Sântana v západnom Rumunsku, ktoré súvisia so zánikovým horizontom lokality (Gogâltan/Sava 2018, 349 nn.). Vyskytovali sa pre-

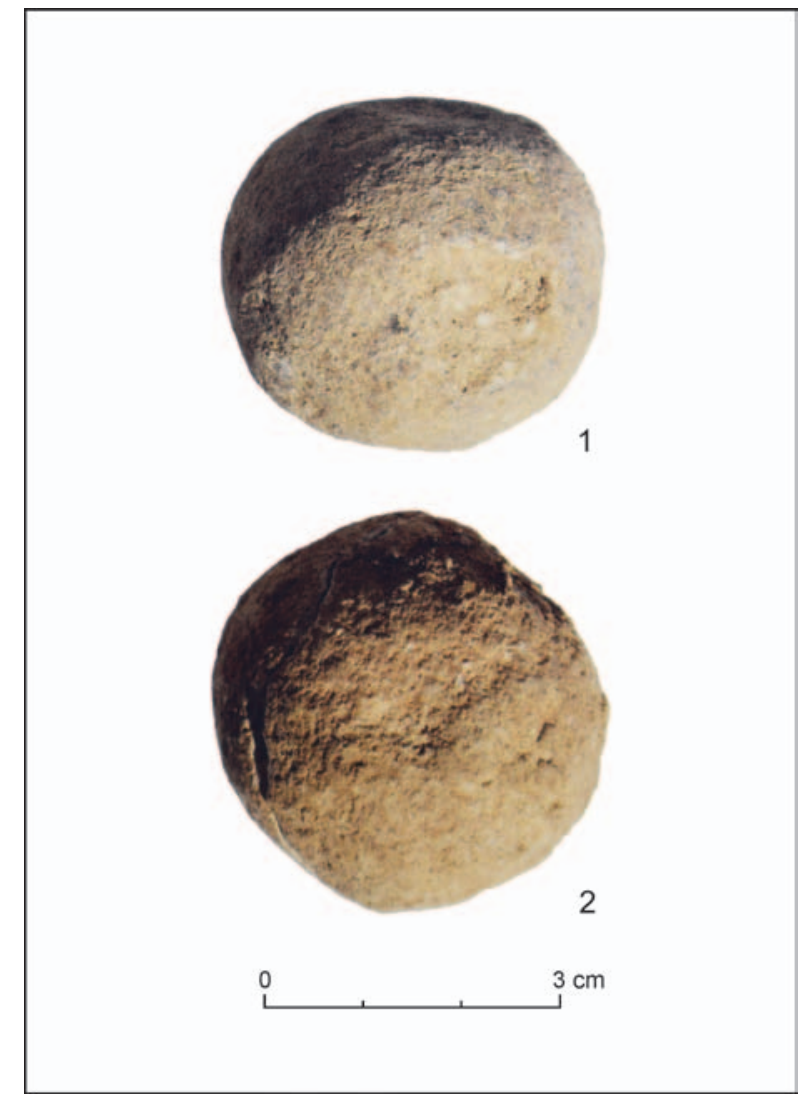

Obr. 12. Nižná Myšla-Várhegy. Potencionálne strelivo do praku z tufitu objavené v priekope opevneného sídliska II (podla Gašaj 2020, 75).

dovšetkým v deštrukcii valového opevnenia, resp. na jeho hrebeni, zriedkavejšie $\mathrm{v}$ obrannej priekope a v iných kontextoch (Gogâltan/Sava 2018, 363). V prípade Nižnej Myšle boli oba celé exempláre objavené v obrannej priekope pred bránou opevnenia (objekt 408). Nie je však vylúčené, že tufové exempláre mohli slúžit aj ako súčast' rôznych hier. V súbore ostatnej industrie sa totiž vyskytujú aj menšie kamenné gul'ky, ktoré mohli byt’ súčastami používanými pri hrách (Olšav 2019, tab. XVIII: 2-6, 12-15). Predmety podobnej funkcie poznáme najmä zo stredoveku (Hoch 2020, 101) alebo napr. zo starovekého Egypta (Hanussek 2020, 25, 72; Kendall 2007, 34).

\section{Predmety s nejasnou funkciou}

Funkcia pieskovcového predmetu so 16-timi jamkami z areálu sídliska je otázna (tab. II: 9). Okrem neho sa na sídlisku II našli dalšie štyri predmety rovnakého charakteru vyrobené z pieskovca alebo tufitu (predmet vyrobený z tufitu má sedem jamiek, dva exempláre majú pät’ a dva po dve jamky). 
Na prvom z uvedených je na vonkajšej (do čierna prepálenej) zaoblenej strane viditelná rytá línia, ktorá mohla umožňovat’ spojenie drôtom, príp. umožňovala lepšiu manipuláciu s kadlubom za pomoci organického materiálu (drevo, koža). Vyhĺbené jamky však nejavia stopy prepálenia, čo spochybňuje účel tohto predmetu ako odlievacej formy alebo dávkovača. Analogické predmety pochádzajú zo sídlisk Novaj-Földvár, kde sa našiel exemplár vyhotovený z pieskovca, a zo sídliska v Maklár-Baglyashalom kde bol exmplár vyrobený z hliny. Na analogických nálezoch sa taktiež nepotvrdili žiadne stopy po špecifickej manipulácii ani po analýze opotrebenia predmetu. Podobné nálezy pochádzajú tiež zo sídlisk Tiszafüred a Füzesabony-Öregdomb (Mengyán 2019, 287, obr. 6: 132; 9: 2). Menší hlinený exemplár (so šiestimi jamkami) vyrobený z hliny pochádza z pohrebiska v Novaj-Földvár (Mengyán 2019, 287, obr. 6: 11). Analýzy exemplárov z Mad’arska nepreukázali žiadne stopy po využití týchto jamiek a uvažuje sa preto o ich kultovej funkcii, príp. mohlo íst' o hraciu dosku (Mengyán 2019, 287). Pozoruhodný je počet jamiek na artefaktoch. Rovnako ako v prípade exemplárov z Nižnej Myšle majú analogické predmety zo sídlisk Novaj-Földvár a Maklár-Baglyashalom 16 jamiek. Opakujúce sa počty jamiek na dalších exemplároch z Nižnej Myšle pravdepodobne nebudú náhodné, rovnako ako fakt, že tento druh predmetu bol vyrábaný z mäkkých, resp. l’ahko opracovatelných materiálov (hlina, tufit, pieskovec). Pri niektorých, zvlášt menších kusoch s menej početnými jamkami sa však nedá vylúčit, že ide o fragmenty pôvodne väčších kusov. Ked'že však hrany na tomto type predmetov bývajú neupravované, nie je úplne zrejmé, v ktorom prípade ide o fragment a v ktorom o celý kus. Masívny vápencový blok $s$ neupravenými okrajmi s tromi radmi jamiek pochádza $\mathrm{z}$ hrobu únětickej kultúry objavenom v Telnici na Brnensku (Kolektiv 2014, 9, obr. 3). Podobné kamene s jamkami z doby bronzovej pochádzajú z oblasti východného Stredomoria (pevninského Grécka, Anatólie a Cypru), pričom sa predpokladá, že mohlo íst’ o hracie dosky a do jamiek sa vkladali kamienky alebo gul'ky. Nevylučuje sa však ani ich funkcia ako predmetov súvisiacich s kultom (Kolektiv 2014, 9). Je možné, že exempláre pochádzajúce z prostredia OFKK mohli byt̉ lokálnymi variantami týchto kameňov a ich výskyt súvisí s kontaktmi so Stredomorím, o ktorých sa nie len v prípade opevneného sídliska v Nižnej Myšli všeobecne nepochybuje (Vladár 1973, 266).

Z kameňa sa okrem praktických nástrojov vyrábali tiež rôzne miniatúry. V prípade Nižnej Myšle o tom svedčia tri tufitové sekeromlaty, ktoré nie sú na opevnených sídliskách doby bronzovej oje- dinelým javom. Ich význam je nejasný, niekedy sa dávajú do súvisu so symbolmi mužského božstva, resp. s kultovou funkciou (Zápotocký/Zápotocká $2008,195)$. Nie je možné vylúčit ani ich funkciu ako detskej hračky.

Ďalšími predmetmi boli závesky (7), kolieska (6), rôzne gul'ky a terčíky, ktoré mohli slúžit ako súčasti hier alebo ako predmety so zatial' nezistenou funkciou (tab. VI: 1, 3, 7-9, 13, 14; Adams 2002, 206). Kamenné okrúhle terčíky a jeden parohový terčík (tab. VI: 5) mohli byt súčastou doskových hier s funkciou hracích kameňov (tab. VI: 4-6). Obdobné exempláre s funkciou hracích kameňov pochádzajú aj z obdobia stredoveku (Hoch 2020, 23 nn.). Podobnú funkciu mohli zohrávat aj väčšie diskovité kamenné exempláre rôznej vel'kosti (15). Terčíky boli vyrábané z črepov nádob a z kameňov príhodného tvaru. Uvažujeme o rovnakej funkcii kamenných aj hlinených predmetov, ich účel je však stále predmetom bádania. Obdobné exempláre sú častým nálezom v období stredoveku a novoveku vo funkcii hracích kameňov (Hoch 2020, 88-90), pričom rovnaký účel týchto predmetov poznáme tiež z etnografických paralel (Adams 2002, 206). Nie je vylúčené, že mohli slúžit aj ako pracovné nástroje slúžiace na brúsenie a škrabanie (Oravkinová 2018, 190). V prípade drobných kamenných (ale tiež hlinených) guliek môžeme uvažovat aj nad možnostou, že mohli byṫ súčastou doskovej hry v kombinácii s nálezmi kamenných plochých predmetov s vyhíbenými jamkami (tab. II: 9).

\section{KAMENNÁ INDUSTRIA NA OPEVNENÝCH SÍDLISKÁCH OFKK}

Zatial čo aktivity súvisiace so ŠI v Nižnej Myšli sa sústredili predovšetkým v dome 416 (a v nedalekej priekope/objekte 408), v domoch 530, 536 a v prilahlom objekte 519, aktivity spojené všeobecne s ostatnou kamennou industriou sa odohrávali predovšetkým v severovýchodnej časti a v okolí východnej brány a v okolí južnejšie umiestneného domu 427. Na opevnených sídliskách OFKK intenzívne prebiehala remeselná výroba. V Spišskom Štvrtku na Myšej hôrke boli doložené areály s domáckou špecializovanou aj individuálnou produkciou, ako aj špecializovaný výrobný areál súvisiaci s metalurgickou činnostou a areál so zriedkavou výrobnou aktivitou. Aktivity špecializovanej domáckej produkcie a špecializovaný výrobný (metalurgický) areál sa nachádzali vo východnej časti opevneného sídliska v okolí vstupnej brány. Aktivity individuálnej/špecializovanej domáckej produkcie sa nachádzali v severovýchodnej a juhovýchodnej časti a zriedkavé doklady výrobných 
aktivít sa nachádzali na akropole opevneného sídliska (Oravkinová 2018, 253).

Aj ked' sa v tomto príspevku venujeme len priestorovej distribúcii kamennej industrie, nápadné podobnosti $\mathrm{v}$ rámci lokalizovania pracovných aktivít medzi Spišským Štvrtkom a Nižnou Myšlou dovolujú uvažovat o dodržiavaní určitých zaužívaných výrobno-ekonomických modelov na opevnených sídliskách OFKK. Určitá špecializovaná výroba, ktorá sa viaže na konkrétne domy je evidovaná aj na výšinnom opevnenom sídlisku OFKK v pol'ských Maszkowiciach (Jędrysik/Przybyła 2018, $31 \mathrm{n}$.). Na eponymnej lokalite, tellovom sídlisku vo Füzesabony-Öreg-Dombe, bola nájdená početná ostatná industria (Horváth a i. 2015, $31 \mathrm{nn}$.) a z nej pozostávajúca skladba súboru velmi podobná tej z Nižnej Myšle. Na opevnenom sídlisku II v Nižnej Myšli evidujeme určité paralely, ale aj určité rozdiely v porovnaní s inými areálmi OFKK na sever a tiež na juh od Nižnej Myšle. Každé zo sídlisk je v rámci produkcie a využívania ŠI a ostatnej industrie v určitom smere špecifické. Napriek tomu spoločne tvoria komplexnejší obraz o využívaní kamenných nástrojov v prostredí OFKK, ktorý odráža podobné hospodárske štruktúry a pracovné postupy v rámci porovnávaných sídlisk (Olšav 2019, 59).

\section{KAMENNÁ A KOVOVÁ INDUSTRIA V KONTEXTE REMESELNÝCH AKTIVÍT}

Dôležitou otázkou pri riešení problematiky remeselných aktivít je ich hospodársko-ekonomický význam. Ten je možné určit na základe intenzity výroby, ktorá sa vztahuje na pracovný čas, ktorý je konkrétnym remeslám venovaný (Duffy 2014, 301). Na základe toho je možné predpokladat', či išlo $\mathrm{v}$ jednotlivých remeslách o domácku produkciu, ktorú v domácnosti vykonávali popri d’alších aktivitách, alebo o špecializovanú produkciu, kontrolovanú miestnymi elitami (Duffy 2014, 69 n.). Podla J. Sofaer $(2010,209-211)$ sa v rámci ŠI v staršej dobe bronzovej stále vyskytovali profesionálni remeselníci, vyrábajúci bifaciálne zahnuté nože, popri špecializovanej systematickej, ale aj bežnej domáckej výrobe. V nasledujúcom období sa však výroba zúžila na domácu - nešpecializovanú produkciu a len v obmedzenej miere pretrvávali profesionálni remeselníci vyrábajúci bifaciálne zahnuté nože. To sa potvrdzuje aj v prípade opevneného sídliska II v Nižnej Myšli zo začiatku strednej doby bronzovej. Aj ked’ boli preukázané určité koncentrácie ŠI, výroba sa odohrávala väčšinou priamo $\mathrm{v}$ domoch a ich bezprostrednom okolí, pričom kvalita finálnych produktov bola nízka.
Naproti tomu silicitový zakrivený nôž je dôkazom vysokej zručnosti jeho zhotovitela. Navyše, jeho pôvod na území dnešného Pol'ska poukazuje na tradíciu špecializovanej výroby tohto typu predmetov mimo priestor zázemia opevneného sídliska v Nižnej Myšli.

Rozdielnu situáciu bolo možné pozorovat pri riešení otázky metalurgickej činnosti. Podla $M$. Jaegera $(2016,127)$ mohli niektoré opevnené sídliská OFKK presahovat' rámec pokrývania potrieb komunity opevneného sídliska a jeho okolia v rámci produkcie farebných kovov, pričom poukazoval práve na opevnené sídliská I a II v Nižnej Myšli. Objav metalurgickej dielne, pyrotechnologických zariadení, množstva kadlubov, téglikov a ich fragmentov, ako aj zliatkov bronzu, túto hypotézu podporujú. Priestorová distribúcia kamenných kadlubov napovedá, že domácka produkcia hrala len minimálnu úlohu a špecializovaná výroba sa odohrávala v severovýchodnej časti opevneného sídliska II. V tomto ohlade je možné domnievat' sa, že tu existovala vrstva špecialistov - metalurgov, ktorých činnost' mohla kontrolovat' miestna elita (Duffy 2014, 69 n.). Samotná metalurgická činnost’ si vyžaduje často nadregionálnu komunikáciu pri získavaní surovín, ako aj špecifické znalosti remeselníkov. V tejto súvislosti rozlišujeme dva stupne špecializovanej výroby: výroba zásobujúca sídlisko, príp. svoje okolie a výroba nadregionálna. Oba typy výroby mohli fungovat' aj vedla seba, pričom špecializované výrobky vysokej kvality (napr. zbrane, doplnky odevu, atd') mohli byt kontrolované elitou, zatial' čo predmety nižšej kvality (napr. jednoduché nástroje) mohli byt vyrábané pre potreby obyvatelov sídliska a jeho okolia. Na produkciu nižšej úrovne nebola potrebná vysoká úroveň zručnosti, pyrotechnologických zariadení, ani vysoká kvalita materiálu, pričom mohli byt využívané zliatky či zvyšky po odlievaní špecializovanej výroby (Jaeger/Olexa 2014, 171 n.; Nicodemus 2014, 309). V Nižnej Myšli je možné predpokladat’ oba stupne metalurgickej činnosti. Špecializovaná výroba sa odohrávala v severovýchodnej časti opevneného sídliska II a výroba nižšej úrovne, ktorá mohla sporadicky prebiehat' $\mathrm{v}$ rôznych častiach sídliska (plán 8). Je nutné pripomenút, že priestorová distribúcia kamenných kadlubov nezahŕňa hlinené tégliky a dýzy a zliatky farebného kovu. Tie sa však vo vyššej miere, okrem objektu 519 (metalurgickej dielne), nachádzali aj v okolí pyrotechnologických zariadení v severovýchodnej časti opevneného sídliska II, a teda v nevel'kej vzdialenosti od objektu 519. Na rozdiel od väčšiny centier doby bronzovej v Karpatskej kotline, v ktorých doklady metalurgickej činnosti poukazujú skôr na výrobu 
pre potreby miestnej komunity, opevnené sídlisko v Nižnej Myšli môžeme priradit k centrám, kde mala metalurgia zásadný význam v ekonomickom živote jeho obyvatelov (Găvan 2015, 472).

Napriek degradácii kamennej industrie $\mathrm{v}$ dobe bronzovej je jej početnost' $\mathrm{v}$ priestoroch opevnených sídlisk značná. Ako možno pozorovat' na opevnených sídliskách v Nižnej Myšli (Olexa 2003), Spišskom Štvrtku (Oravkinová 2018), Košiciach-Barci (Hájek 1954, 584 nn.), Rozhanovciach (Gašaj 1983, 130 nn.) a d’alších opevnených sídliskách OFKK, kovová industria zohrávala stále predovšetkým prestížnu funkciu.

Bronzové sekery, sekeromlaty a kosáky sú skôr výnimočnými nálezmi a ich funkcia nie je jednoznačná, ked’že okrem samotných nástrojov mohlo íst’ aj o symbolické či rituálne predmety (najmä v prípade bronzových kosákov) alebo zbrane (bronzové sekery a sekeromlaty).

Pomerne vysoké zastúpenie kadlubov na ploché sekery (štyri exempláre) by zas mohlo nasvedčovat', že sa nástroje tohto typu na opevnenom sídlisku II v Nižnej Myšli vyskytovali a reálne využívali, avšak nálezy plochých sekier nateraz úplne absentujú. Táto situácia môže byt̉ spôsobená aj opätovným pretavovaním bronzových predmetov, ktoré boli znehodnotené. Ak pripustíme, že bronzové kosáky a sekery boli skutočne využívané aj na pracovné účely, ich počet oproti kamenným nástrojom je stále zanedbatel'ný. Upozorňuje to na možnost', že z hladiska materiálu bola rozhodujúca hmotnost', resp. kvantita. Zatial' čo si obyvatelia mohli dovolit' vyrobit drobné pracovné predmety aj $\mathrm{z}$ bronzu (napr. ihly, šidlá a pod.), čo dokazuje ich pomerne početné zastúpenie, nástroje, ktoré si vyžadovali vyššie množstvo kovu na výrobu, boli opätovne pretavované, ale najmä stále nahradzované kamennými. Súčasne technologické a kvalitatívne prevedenie týchto nástrojov bolo na pomerne nízkej úrovni, ako naznačuje aj rozbor kamenných predmetov v tejto práci. Kedže v dobe bronzovej prevzal kov prestížnu funkciu, znižovanie kvality kamenných nástrojov sa javí ako logické. Naopak vysoký počet nástrojov ŠI dokladá, že boli stále bežnou súčastou života ludí v staršej a strednej dobe bronzovej a to aj napriek tomu, že môžeme sledovat postupné nahrádzanie kameňa kovom. Pri výstavbe opevneného sídliska s drevozemným opevnením a stavbami, ktorých základný stavebný materiál tvorí drevo, bolo potrebné množstvo l’udí, materiálu, ale taktiež nástrojov. Množstvo deformovaných a zlomených nástrojov na opevnenom sídlisku v Nižnej Myšli dokazuje, že sa tieto aktivity diali priamo na sídlisku a vysoký počet kamenných nástrojov na opevnených sídliskách staršej a strednej doby bronzovej je tak opodstatnený. Aj ked' kovová industria mala stále predovšetkým prestížny charakter, už na počiatku strednej doby bronzovej pozorujeme postupné, aj ked’ pomalé nahrádzanie pracovných nástrojov vyrobených z kameňa, kosti či parohu za ich bronzové prevedenia. Toto tvrdenie demonštrujeme na príklade opevneného sídliska II v Nižnej Myšli, kde sa v jednom časovom horizonte vedla seba vyskytujú parohové, kamenné a bronzové dlátka, kostené a kovové ihly a šidlá, kamenné sekery a ich bronzové náprotivky, ktorých výrobu dokladajú kamenné odlievacie formy. Spolu s nimi sa tiež našli bronzové kosáky, kamenné zahnuté nože a kompozitné kosáky s upevnením čepielok do násady, na ktorých je prítomný tzv. kosákový lesk. Postupné nahrádzanie kameňa bronzom je pozorovatelné aj v rámci hrotov šípov v pomere 15 kamenných k siedmim bronzovým hrotom šípov. Ďalším unikátnym nálezom je fragment bronzovej pílky. V mladších obdobiach doby bronzovej sú bronzové nástroje pomerne bežným elementom. Prestíž bola vyjadrená skôr v kontexte umeleckého prevedenia a technologickej úrovne predmetu, než v samotnom materiáli. Napriek tomu sa v obmedzenej miere využívanie kamenných nástrojov udržalo až do záveru doby bronzovej. 

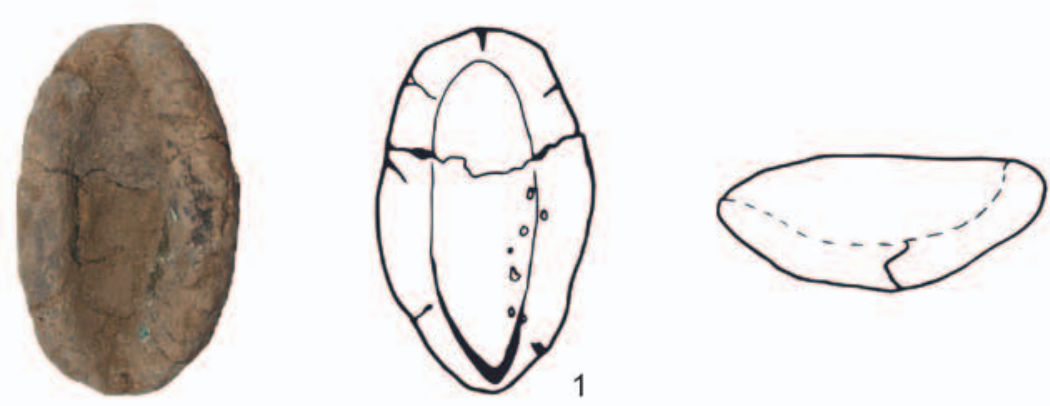

0
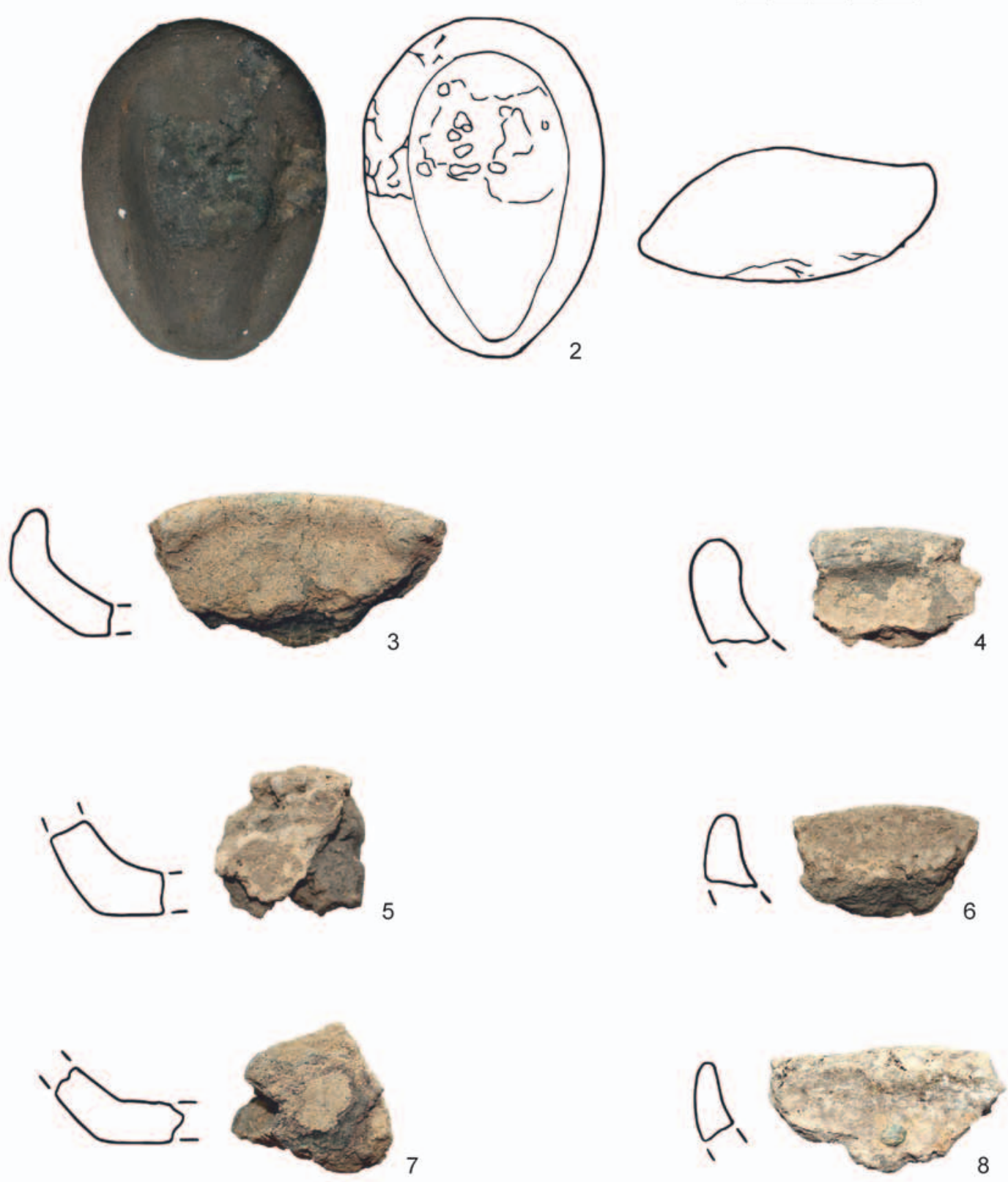

Tab. I. Nižná Myšla-Várhegy. Hlinené tégliky a ich fragmenty z objektu 519. 


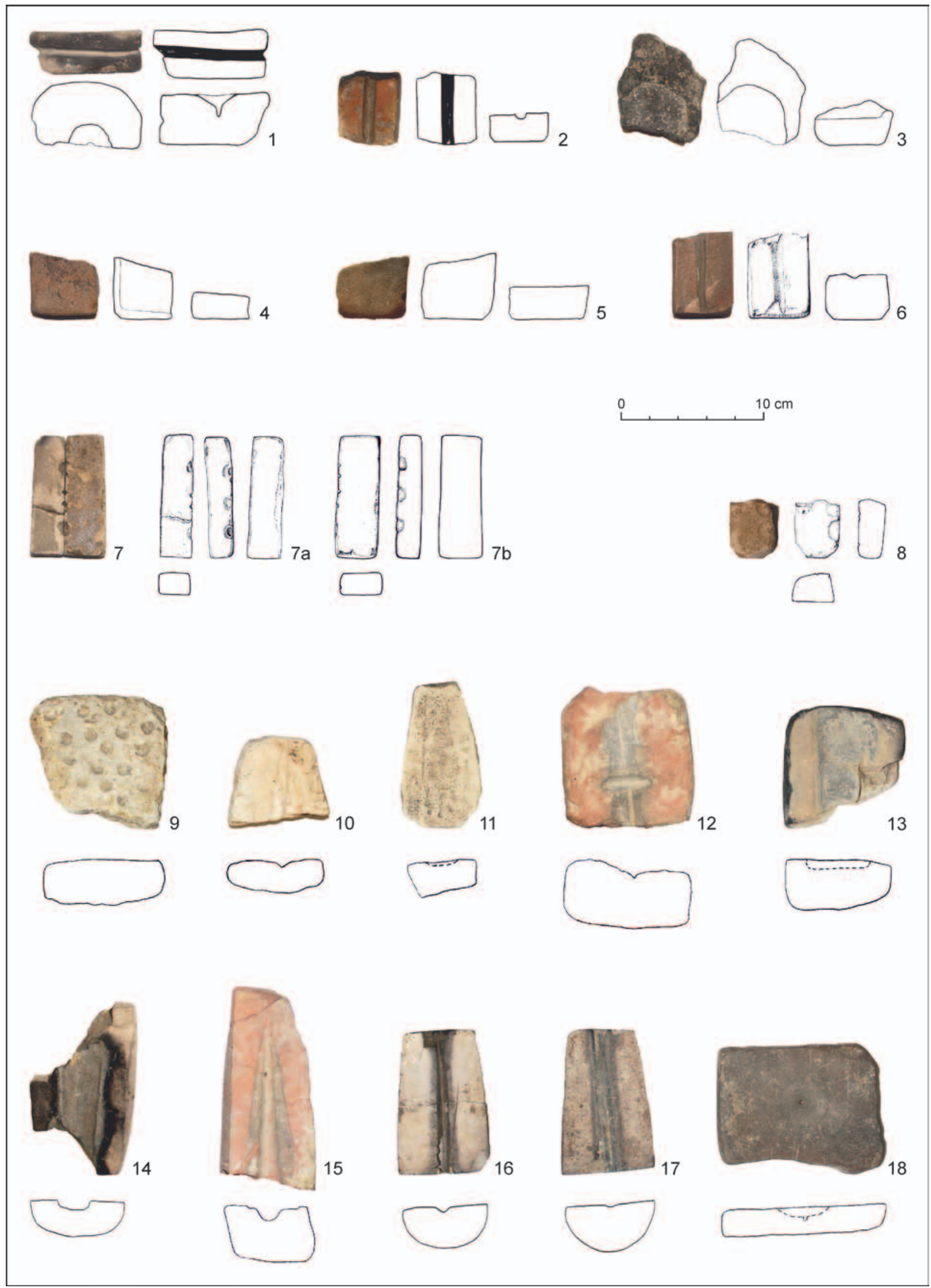

Tab. II. Nižná Myšla-Várhegy. 1-8, 10-18 - výber kamenných kadlubov z opevneného sídliska II; 9 - predmet z tufitu (hracia doska/kultový predmet), pôvodne pokladaný za kadlub. 

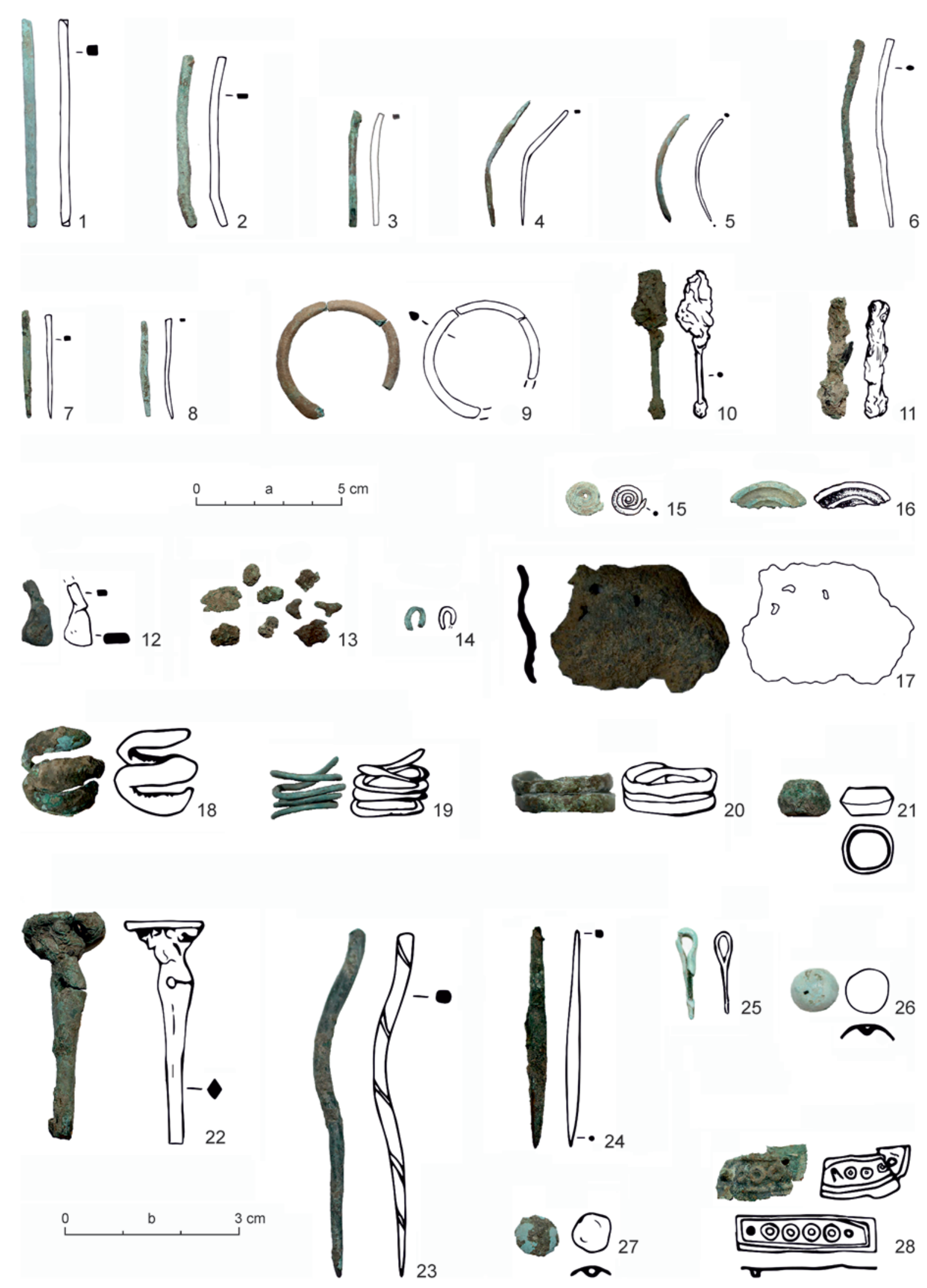

Tab. III. Nižná Myšla-Várhegy. Výber kovových predmetov z objektu 519. Mierka: a - 1-17; b - 18-28. 


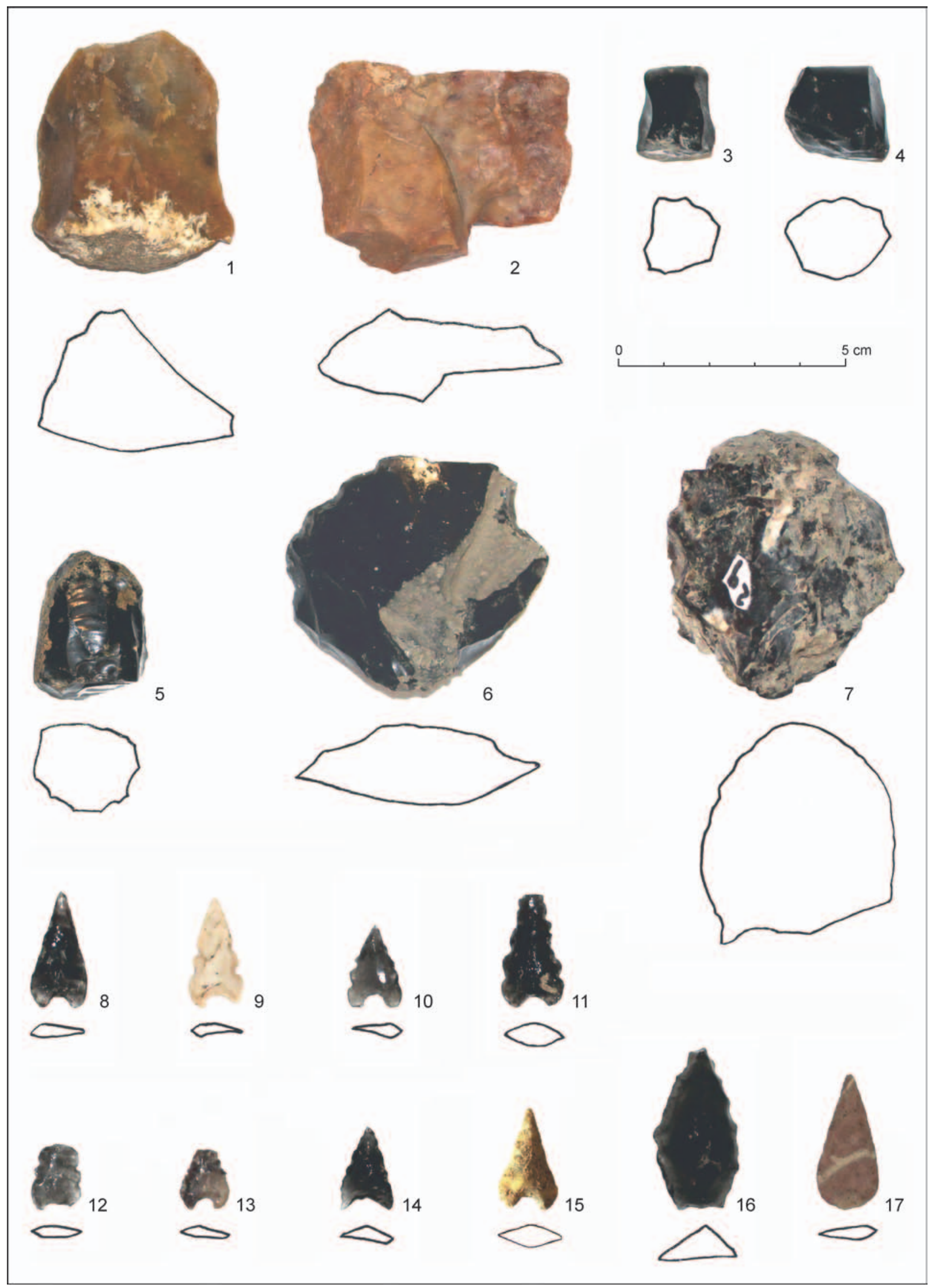

Tab. IV. Nižná Myšla-Várhegy. 1-7 - jadrá; 8-15 - kamenné hroty šípov; 16, 17 - polotovary na výrobu hrotov šípov. 

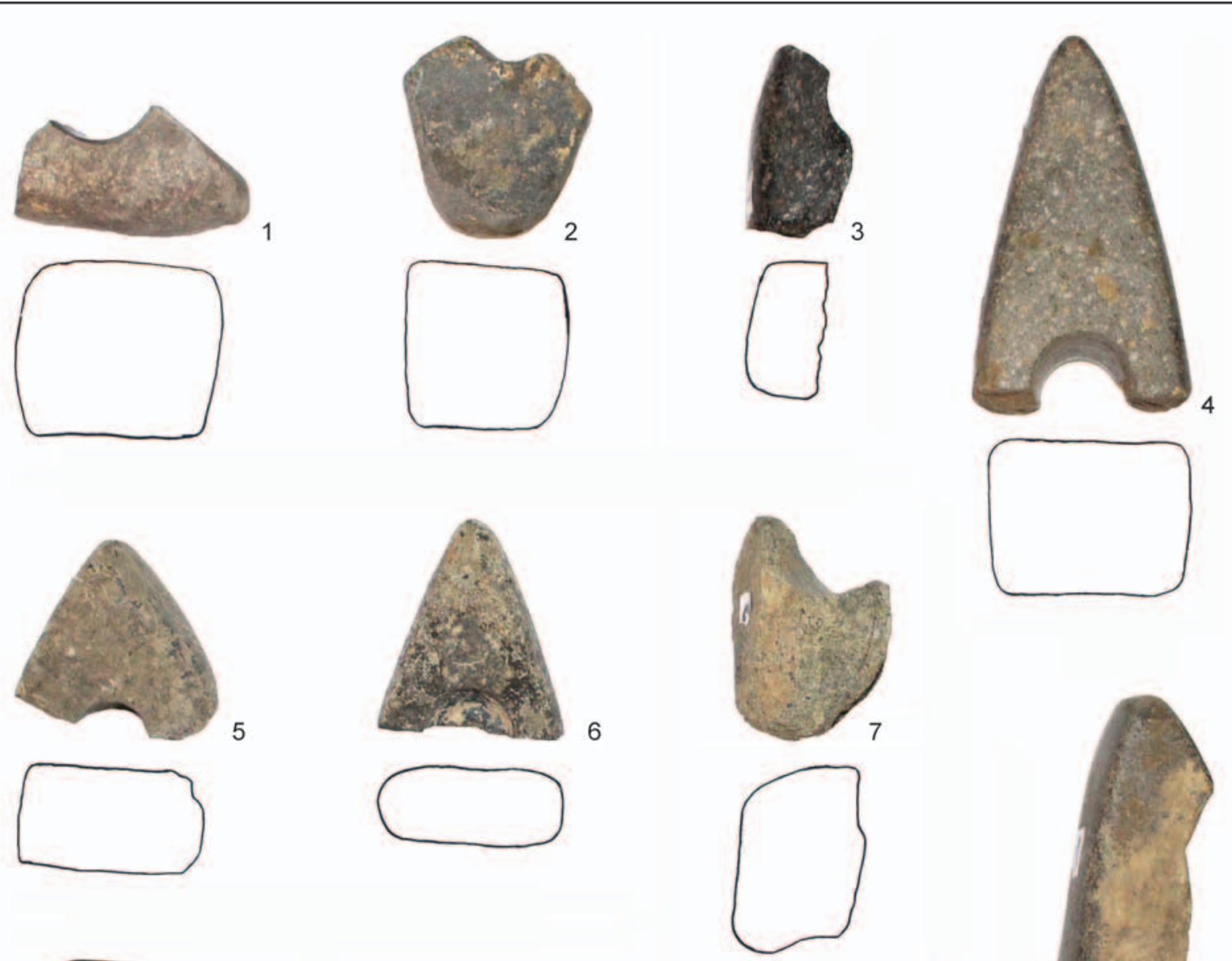

\section{6}
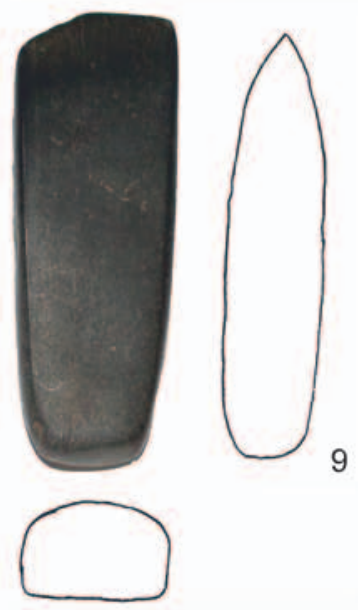

9
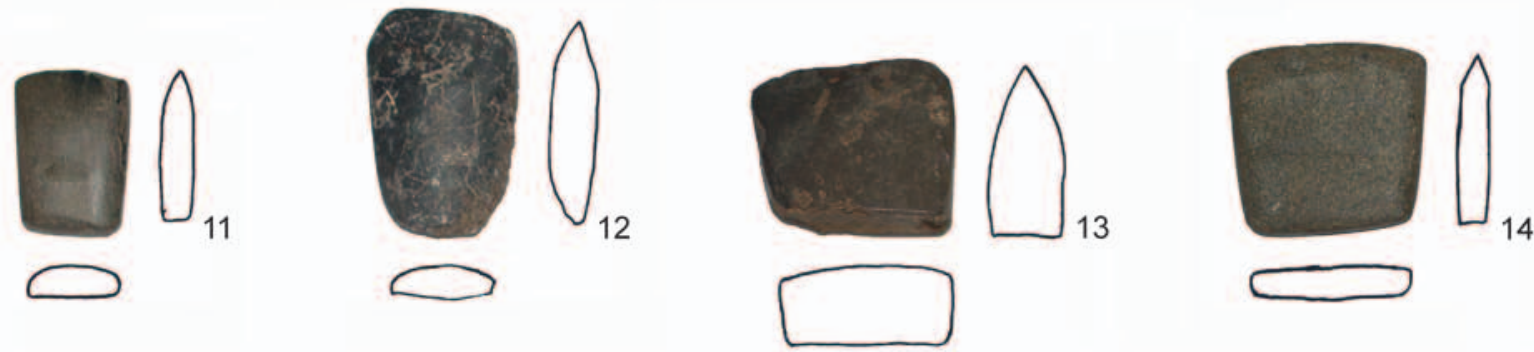

Tab. V. Nižná Myšla-Várhegy. 1-8 - fragmenty kamenných sekeromlatov; 9, 11-14-kamenné sekery a ich fragmenty; 10 - kamenné dlátko. 


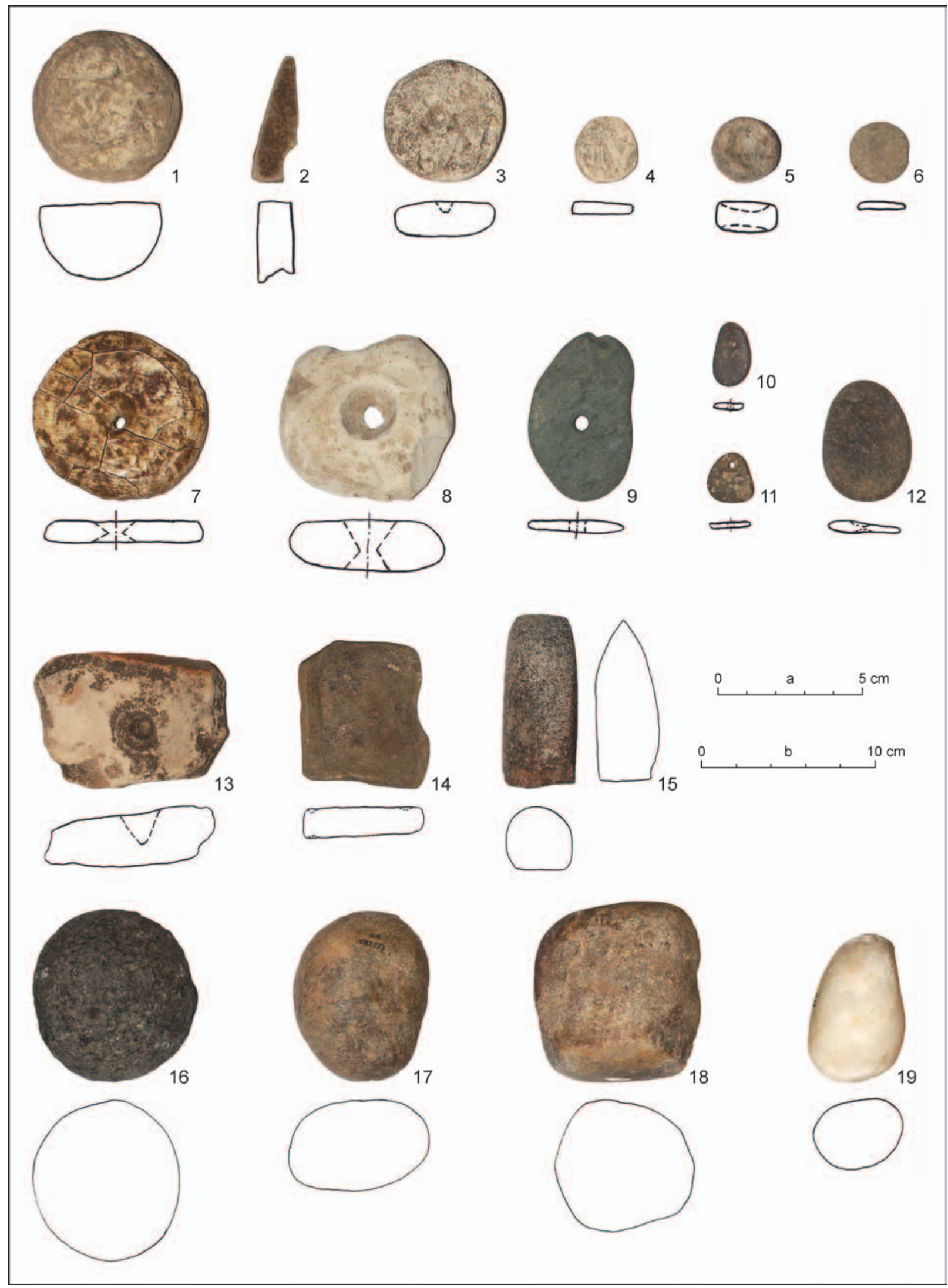

Tab. VI. Nižná Myšla-Várhegy. 1, 9, 13, 14 - kamenné predmety s neznámou funkciou; 2 -fragment miniatúry sekeromlatu z tufitu; 4, 6-kamenné terčíky; 5 - parohový terčík; 3, 7, 8-perforované tufitové okrúhle predmety; 10-12 - kamenné závesky; 15 - kopytovitý klin; 16-19 - drvidlá. Mierka: a -1-12; b-13-19. 


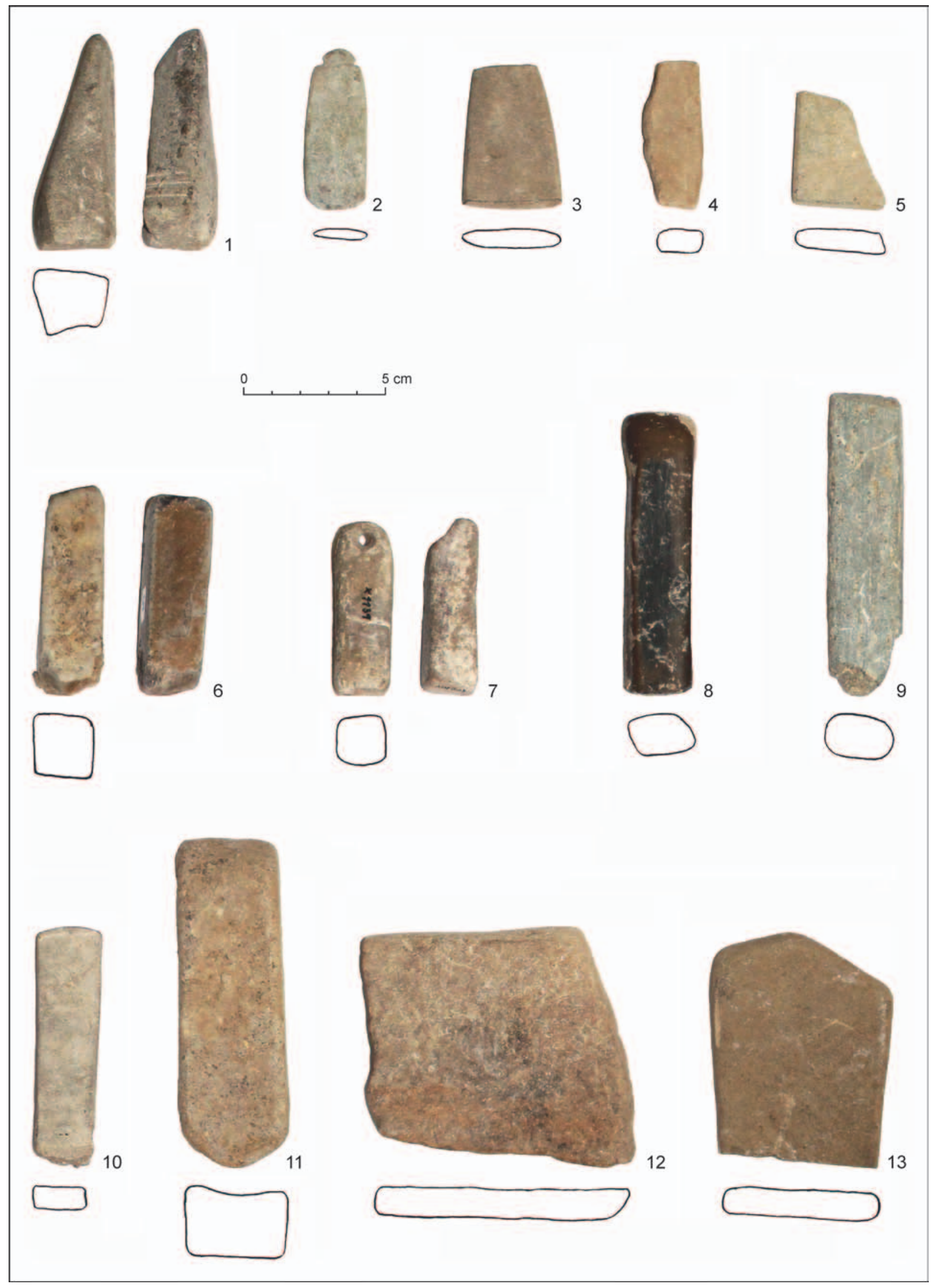

Tab. VII. Nižná Myšla-Várhegy. 1-11 - brúsiky; 12, 13 - pasívne nástroje na brúsenie. 


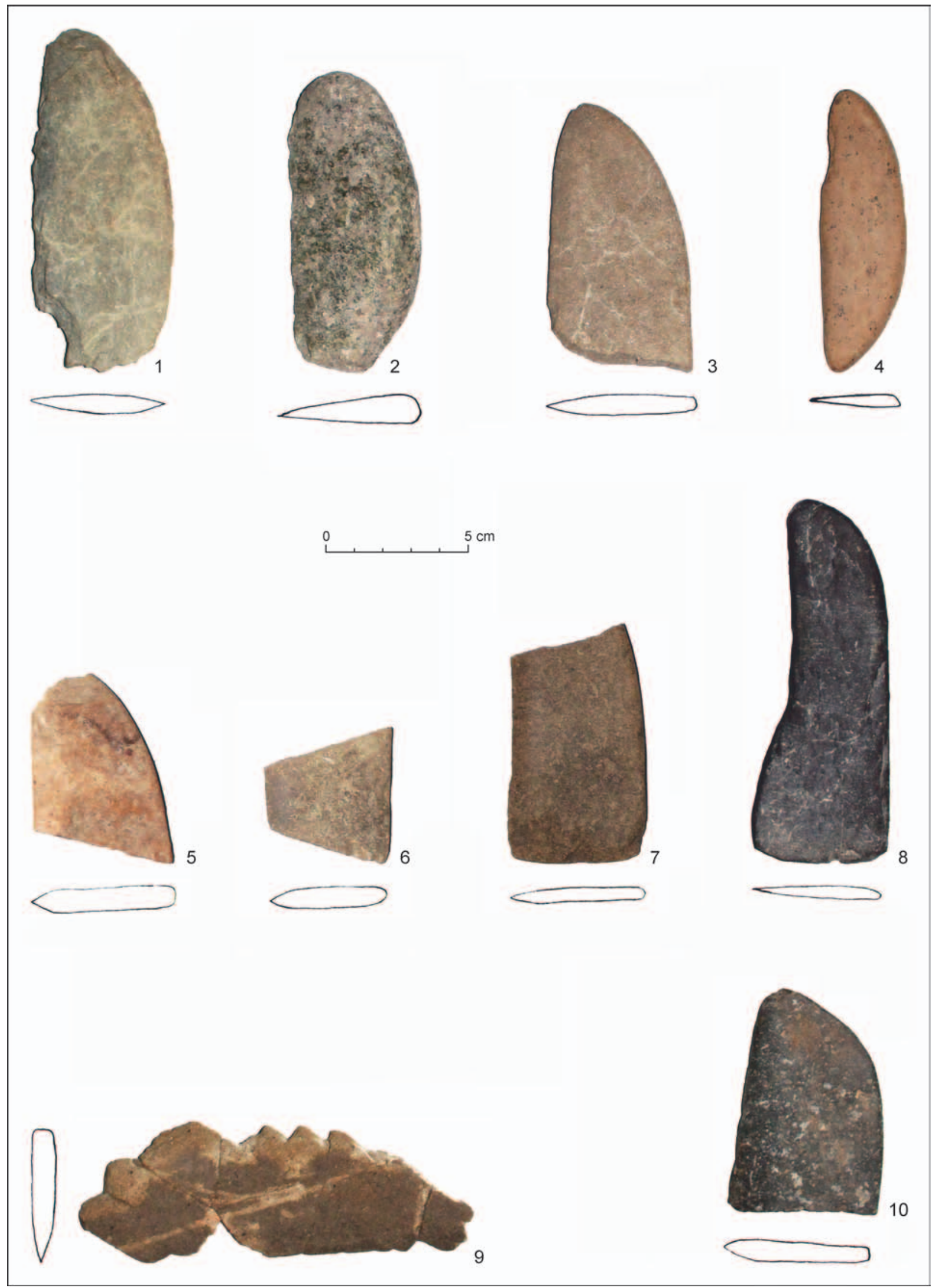

Tab. VIII. Nižná Myšla-Várhegy. Zahnuté kamenné nože z opevneného sídliska II. 


\section{LITERATÚRA}

Adams 2002 - J. L. Adams: Ground Stone Analysis. A Technological Approach. Utah 2002.

Bátora 2009 - J. Bátora: Metallurgy and Early Bronze Age Fortified Settlements in Slovakia. Slovenská archeológia 57, 2009, 195-219.

Bátora 2018 - J. Bátora: Slovensko v staršej dobe bronzovej. Bratislava 2018

Bayley/Crossley/Ponting 2008 -J. Bayley/D. Crossley /M. Ponting (eds.): Metals and Metalworking. A research framework for archaeometallurgy. HMS Occasional Publication No 6. London 2008.

Bayley/Rehren 2007 - J. Bayley/Th. Rehren: Towards a functional and typological classification of crucibles. In: S. La Niece/D. Hook/P. Craddock (eds.): Metals and Mines. Studies in Archaeometallurgy. London 2007, 46-55.

Bentsen 2014 - S. E. Bentsen: Using Pyrotechnology: Fire-related Features and Activities with a Focus on the African Middle Stone Age. Journal of Archaeological Research 22, 2014, 141-175.

DOI: https://doi.org/10.1007/s10814-013-9069-x

Berňakovič 1961 - K. Berňakovič: Hromadné nálezy z doby bronzovej z územia na pravom brehu Hornej Tisy (Zakarpatská oblast' USSR). Študijné zvesti AÚ SAV 4, 1961, 5-108.

David 2002 - W. David: Studien zu Ornamentik und Datierung der bronzezeitlichen Depotfundgruppe Hajdúsámson-Apa-Ighiel-Zajta. Teil 1. Bibliotheca Musei Apulensis 18. Alba Iulia 2002.

Duffy 2014 - P. R. Duffy: Complexity and Autonomy in Bronze Age Europe. Assessing Cultural Developments in Eastern Hungary. Budapest 2014.

Ďuriš 2018 - J. Ďuriš: Radzovce v období popolnicových polí. Architektonická rekonštrukcia stavieb na základe analýzy mazanice. Nitra 2018.

Dzurušová 2012 - M. Dzurušová: Kovová industria z pohrebiska Dvorníky-Včeláre a súčasné osídlenie Slovenského krasu. Bakalárska práca. Masarykova univerzita v Brne. Filozofická fakulta. Brno 2012. Dostupné na: https://is.muni.cz/th/nlfmq/

Eccleston/Ottaway 2002 - M. Eccleston/B. S. Ottaway: Experimental Casting of Copper and Bronze in Sand Moulds. In: E. Jerem/K. T. Biró (eds.): Archaeometry 98. Proceedings of the 31 ${ }^{\text {st }}$ Symposium. Budapest, April 26-May 3, 1998, Volume I. BAR International Series 1043. Oxford 2002, 185-189.

Fischl 2006 - K. P. Fischl: Ároktö-Dongóhalom bronzkori tell telep. Miskolc 2006.

Fischl/Kiss/Kulcsár 2013 - K. P. Fischl/V. Kiss/G. Kulcsár: Specialised Households in the Carpathian Basin during the Early and Middle Bronze Age. In: B. Rezi/R. E. Németh/S. Berecki (eds.): Bronze Age Crafts and Craftsmen in the Carpathian Basin. Proceedings of the International Colloquium from Târgu Mureş. 5-7 October 2012. Târgu Mureş 2013, 9-22.

Fontijn 2002 - D. R. Fontijn: Sacrificial landscapes. Cultural biographies of persons, objects and 'natural' places in the Bronze Age of the southern Netherlands, c. 2300-600 BC. Analecta Praehistorica Leidensia 33/34. Leiden 2002.

Freestone 1989 - I. C. Freestone: Refractory Materials and Their Procurement. In: A. Hauptmann/E. Pernicka/ G. A. Wagner (Hrsg.): Archäometallurgie der Alten Welt. Beiträge zum Internationalen Symposium „Old World Ar- chaometallurgy", Heidelberg 1987 - Old World Archaeometallurgy. Proceedings of the International Symposium „Old World Archaometallurgy", Heidelberg 1987. Der Anschnitt. Beiheft 7. Heidelberg 1989, 155-162.

Frînculeasa/Garvăn/Preda-Bălănică 2019 - A. Frînculeasa/ D. Garvăn/B. Preda-Bălănică: Curved Stone Knives of the Krummesser Type Recently Discovered in Northern Muntenia. In: V. Sîrbu/A. Comşa/D. Hortopan (eds.): Digging in the past of old Europe. Studies in Honor of Cristian Schuster at his $60^{\text {th }}$ Anniversary. Târgu Jiu - Brăila 2019, 125-138.

Furmánek 2010 - V. Furmánek: Radzovce. Osada l’udu popolnicových polí. Nitra 2010.

Furmánek 2015 - V. Furmánek (zost.): Staré Slovensko 4. Doba Bronzová. Nitra 2015.

Furmánek/Veliačik/Vladár 1991 - V. Furmánek/L. Veliačik/ J. Vladár: Slovensko v dobe bronzovej. Bratislava 1991.

Gačková 1999 - L. Gačková: Kosákovitý nástroj z Lúčok. AVANS 1997, 1999, 46.

Gašaj 1983 - D. Gašaj: Výsledky záchranného výskumu opevnenej osady otomanskej kultúry v Rozhanovciach. Archeologické rozhledy 35, 1983, 130-137.

Gašaj 2002 - D. Gašaj: Fortified settlements and their economic life. In: J. Gancarski (ed.): Między Mykenami a Battykiem. Kultura Otomani-Füzesabony. Krosno - Warszawa 2002, 21-52.

Gašaj 2020 - D. Gašaj: Zbrane a zbroj doby bronzovej. Košice 2020.

Gašaj/Olexa 1996 - D. Gašaj/L. Olexa: Nižná Myšla in der Bronzezeit. Košice 1996.

Găvan 2013 - A. Găvan: Metallurgy in the Bronze Age Tell Settlements from the Carpathian Basin. Iaşi 2013.

Găvan 2015 - A. Găvan: Metal and Metalworking in the Bronze Age Tell Settlements from the Carpathian Basin. Cluj-Napoca 2015.

Gogâltan/Sava 2018 - F. Gogâltan/V. Sava: A Violent End. An Attack with Clay Sling Projectiles against the Late Bronze Age Fortification in Sântana, South-Western Romania. In S. Hansen/R. Krause (Hrsg.): Bronzezeitliche Burgen zwischen Taunus und Karpaten. Bronze Age. Hillforts between Taunus and Carpathian Mountains. Beiträge der Ersten Internationalen LOEWE-Konferenz vom 7. bis 9. Dezember 2016 in Frankfurt/M. Proceedings of the First International LOEWE Conference, 7-9 december 2016 in Frankfurt/M. Universitätsforschungen zur prähistorischen Archäologie 319. Prähistorische Konfliktforschung 2. Bonn 2018, 349-369.

Hájek 1954 - L. Hájek: Zlatý poklad v Barci u Košic. Archeologické rozhledy 6, 1954, 584-587.

Hanussek 2020 - B. Hanussek: Mehen and the Cultural Memory: Incorporating, Maintaining and Obliviating a Board Game Practice in Ancient Egypt. Praca licencjarska. Uniwersytet Warszawski. Instytut Archeologii. Warszawa 2020. Dostupné na: https://www.academia. edu/43745367/Mehen_and_the_Cultural_Memory_Incorporating_Maintaining_and_Obliviating_a_Board_Game_Practice_in_Ancient_Egypt

Hoch 2020 - A. Hoch (ed.): Svět středověkých her. Jihlava 2020. Horváth a i. 2015 - T. Horváth/A. Farkas-Pető/I. Farkas/ J. Mihály/B. Péterdi: The Stone Implements of the Middle Bronze Age Tell Settlement of Füzesabony-Öreg-Domb. Slovenská archeológia 63, 2015, 31-62. 
Hovorka 2008 - D. Hovorka: Príspevok petroarcheológie k poznaniu hmotnej kultúry kamennej doby územia Slovenska. In: V. Hašek/R. Nekuda/M. Ruttkay (ed.): Ve službách archeologie 1. Brno 2008, 97-105.

Childe 1930 - V. G. Childe: The Bronze Age. London 1930.

Chropovský 1960 - B. Chropovský: Pohrebisko zo staršej doby bronzovej vo Vel'kom Grobe. In: B. Chropovský/ M. Dušek/B. Polla: Pohrebiská zo staršej doby bronzovej na Slovensku 1. Bratislava 1960, 30-133.

Ilon 2014 - G. Ilon: Opfergrube der Hügelgräberkultur in der Gemarkung von Ménfőcsanak Spiralornament Auf Einem Tonfries Eines Gebäudes. Acta Archaeologica Academiae Scientiarum Hungaricae 65, 2014, 5-42. DOI: https://doi.org/10.1556/AArch.65.2014. 1. 1

Jaeger 2016 - M. Jaeger: Bronze Age Fortified Settlements in Central Europe. Poznań 2016.

Jaeger/Olexa 2014-M. Jaeger/L. Olexa: The Metallurgists from Nižná Myšla. A Contribution to the Discussion on the Metallurgy in Defensive Settlements of the OtomaniFüzesabony Culture. Archäologisches Korrespondenzblatt 44, 2014, 163-176.

Janšák 1935 - Š. Janšák: Praveké sídliská s obsidiánovou industriou na východnom Slovensku. Bratislava 1935.

Ježek 2017 - M. Ježek: Archaeology of touchstones. An introduction based on finds from Birka, Sweden. Leiden 2017.

Jędrysik/Przybyła 2018 - J. Jędrysik/M. S. Przybyła: Bronze Age fortified settlement on Zyndram's Hill at Maszkowice (Polish Carpathians). Gesta 17/2, 2018, 9-33.

Kendall 2007 - T. Kendall: Mehen: The Ancient Egyptian Game of the Serpent. In: I. L. Finkel (ed.): Ancient Board Games in Perspective. Papers from the 1990 British Museum colloquium with additional contributions. London 2007, 33-45.

Kienlin 2007 - T. Kienlin: Von den Schmieden der Beile: $\mathrm{Zu}$ Verbreitung und Angleichung metallurgischen Wissens im Verlauf der Frühbronzezeit. Praehistorische Zeitschrift 82, 2007, 1-22.

DOI: https://doi.org/10.1515/PZ.2007.001

Kiss 2009 - V. Kiss: The Life Cycle of Middle Bronze Age Bronze Artefacts from the Western Part of the Carpathian Basin. In: T. L. Kienlin/B. W. Roberts (eds.): Metals and Societies. Studies in honour of Barbara S. Ottaway. Universitätsforschungen zur prähistorischen Archäologie 169. Bonn 2009, 328-335.

Kolektiv 2014 - Kolektiv autorů: Mykény a střední Evropa. Počátky evropských civilizací v době bronzové. Brno 2014.

Kmetová/Hladíková/Gregor 2010 - P. Kmetová/K. Hladíková/M. Gregor: Plasticky zdobená mazanica z Levíc-Géne. In: V. Furmánek/E. Miroššayová (ed.): Popolnicové polia a doba halštatská. Archaeologica Slovaca Monographiae 11. Nitra 2010, 139-159.

Kopacz 2001 - J. Kopacz: Krummesser - Poczatki epoki brazu w strefie karpackiej w świetle materiałów kamiennych. Kraków 2001.

Kopacz 2011 - J. Kopacz: Krummesser - Périphéries des industries lithiques taillées. Acta Archaeologica Carpathica 46, 2001, 61-82.

Kovács 1975 - T. Kovács: Historische und chronologische Fragen des Überganges von der Mittleren-zur Spätbronzezeit in Ungarn. Acta Archaeologica Academiae Scientiarum Hungaricae 27, 1975, 297-317.

Kraus a i. 2015 - S. Kraus/Ch. Schröder/S. Klemm/E. Pernicka: Archaeometallurgical studies on the slags of the Middle Bronze Age copper smelting site S1, Styria,
Austria. In: A. Hauptmann/D. Modarressi-Tehrani (eds.): Archaeometallurgy in Europe III. Proceedings of the $3^{\text {rd }}$ International Conference Deutsches Bergbau-Museum Bochum. June 29-July 1, 2011. Bochum 2015, 301-308.

Kučerová 2012 - M. Kučerová: Záchranný výskum vo Vel'kej Lomnici. AVANS 2010, 2012, 137, 138.

Lamiová-Schmiedlová 2009 - M. Lamiová-Schmiedlová: Žiarové pohrebisko z mladšej doby bronzovej na lokalite Dvorníky-Včeláre. Archaeologica Slovaca Monographiae. Catalogi 11. Nitra 2009.

Libera a i. 2015 - J. Libera/J. Górski/P. Włodarczak/M. Florek/L. Orszulak: Krummesser in the Upper Vistula River Basin. Acta Archaeologica Carpathica 50, 2015, 69-100.

Luštík/Mihok/Olexa 1991 - J. Luštík/L. Mihok/ L. Olexa: Metalografický rozbor bronzových predmetov z Nižnej Myšle. Archeologické rozhledy 43, 1991, 138-144.

Machnik 1972 - J. Machnik: Die Mierzanowice-Koštany-Kultur und das Karpatenbecken. Slovenská archeológia 20, 1972, 177-188.

Makarowicz/Górski/Lysenko 2013 - P. Makarowicz/J. Górski/S. D. Lysenko: Pontic and Transcarpathian Cultural Patterns in the Trzciniec Circle between the Prosna and Dnieper. In: A. Kośko (ed.): The Ingul-Donets Early Bronze Civilization as Springboard for Transmission of Pontic Cultural Patterns to the Baltic Drainage Basin 3200-1750 BC. Baltic-Pontic studies 18. Poznań 2013, 162-202.

Mengyán 2019 - Á. Mengyán: Middle Bronze Age Finds from the Southern Foothills of the Bükk Mountains (North-eastern Hungary). Case Studies of MaklárBaglyashalom, Novaj-Földvár and Szihalom-Árpád vár. In: K. P. Fischl/T. L. Kienlin (eds.): Beyond Divides - The Otomani-Füzesabony Phenomenon. Current Approaches to Settlement and Burial in the North-eastern Carpathian Basin and Adjacent Areas. Universitätsforschungen zur prähistorischen Archäologie 345. Bonn 2019, 277-294.

Mihok/Olexa/Briančin 1998 - L'. Mihok/L. Olexa/J. Briančin: Production of bronze age gold object. Karpatyka 5, 1998, 5-15.

Mozsolics 1967 - A. Mozsolics: Bronzefunde des Karpateneckens. Depotfundhorizonte von Hajdúsámson und Kosziderpadlás. Budapest 1967.

Mozsolics/Schalk2000 - A. Mozsolics/E. Schalk: Bronzefunde aus Ungarn. Depotfundhorizonte Hajdúböszörmény. Románd und Bükkszentlászló. Prähistorische Archäologie in Südosteuropa 17. Kiel 2000.

Nessel a i. 2018 - B. Nessel/G. Brügmann/C. Frank/J. Marahrens/E. Pernicka: Tin Provenance and Raw Material Supply - Considerations about the Spread of Bronze Metallurgy in Europe. Metalla 24/2, 2018, 65-72.

Nicodemus 2014 - A. J. Nicodemus: Bronze Age Economies of the Carpathian Basin: Trade, Craft Production, and Agro-Pastoral Intensification. A dissertation submitted in partial fulfillment of the requirements for the degree of Doctor of Philosophy (Anthropology) in the University of Michigan. Michigan 2014. Dostupné na: https://deepblue.lib.umich.edu/handle/2027.42/107331

Nováček 2010 - T. Nováček: Pohrebisko otomansko-füzesabonyskej kultúry na lokalite Nižná Myšla - nekeramické pamiatky staršieho horizontu. Bakalárska práca. Masarykova univerzita v Brne. Filozofická fakulta. Brno 2010.

Nováček 2017 - T. Nováček 2017: Vyhodnotenie materiálu pohrebiska otomansko - füzesabonyského kultúrneho komplexu v Nižnej Myšli (hroby 1-792). Dizertačná práca. 
Masarykova univerzita v Brne. Filozofická fakulta. Ústav archeologie a muzeologie. Brno 2017. Dostupné na: https://is.muni.cz/th/t60t7/

Novotná 1980 - M. Novotná: Die Nadeln in der Slowakei. Prähostorische Bronzefunde XIII/6. München 1980.

Novotná 1982 - M. Novotná: Metalurgia medi a bronzu v dobe bronzovej na Slovensku. Archeologia Polski 27, 1982, 359-369.

Novotná 2010 - M. Novotná: Fernkontakte und Handelsaustausch in der Urnenfelderzeit. In: V. Furmánek/ E. Miroššayová (ed.): Popolnicové polia a doba halštatská. Archaeologica Slovaca Monographiae 11. Nitra 2010, 269-276.

Nørgaard 2017 - H. W. Nørgaard: Portable XRF on Prehistoric Bronze Artefacts: Limitations and Use for the Detection of Bronze Age Metal Workshops. Open Archaeology 3, 2017, 101-122. DOI: https://doi.org/10.1515/opar-2017-0006

Olexa 1987 - L. Olexa: Gräber von Metallgiessern in Nižná Myšla. Archeologické rozhledy 39, 1987, 255-275.

Olexa 2003 - L. Olexa: Nižná Myšl'a. Osada a pohrebisko z doby bronzovej. Košice 2003.

Olexa/Nováček 2013 - L. Olexa/T. Nováček: Pohrebisko zo staršej doby bronzovej v Nižnej Myšli. Katalóg I (hroby 1-310). Nitra 2013.

Olexa/Nováček 2015 - L. Olexa/T. Nováček: Pohrebisko zo staršej doby bronzovej v Nižnej Myšli. Katalóg II (hroby 311-499). Nitra 2015.

Olšav 2019 - Š. Olšav: Vyhodnotenie nálezov z lokality Várhegy II z počiatkov strednej doby bronzovej. Kamenná industria z Nižnej Myšle. Diplomová práca. Univerzita Komenského v Bratislave. Filozofická fakulta. Katedra archeológie. Bratislava 2019. Dostupné na: https:/opac. crzp.sk/?fn=detailBiblioForm \& sid=7F8A1CD40EE33064DFD366190E37 \& seo=CRZP-detail-kniha

Olšav/Olexa 2020 - Š. Olšav/L. Olexa: Predbežné výsledky výskumu v Nižnej Myšli v roku 2019. In: M. Musilová (red.): Stretnutie východoslovenských archeológov. Zborník príspevkov z 28. stretnutia v Stropkove v roku 2019. Nitra 2020, 29-36.

Oravkinová 2018 - D. Oravkinová: Výšinné opevnené sídlisko otomanskej kultúry v Spišskom Štvrtku v kontexte Karpatského kultúrneho vývoja. Dizertačná práca. Univerzita Komenského v Bratislave. Filozofická fakulta. Bratislava 2018. Nepublikované.

Oravkinová/Hromadová/Vlačiky 2017 - D. Oravkinová/B. Hromadová/M. Vlačiky: Kostená a parohová industria z výšinného opevneného sídliska v Spišskom Štvrtku. Slovenská archeológia 65, 2017, 23-80.

Oravkinová/Vladár 2021 - D. Oravkinová/J. Vladár: Some Are More Eaqual Than Others: Intrasettlement Social Organization in Spišský Štvrtok (EBA/MBA, Slovakia). Cambridge Archaeological Journal 31, 2020, 183-210. DOI: https://doi.org/10.1017/s0959774320000311

Pančíková 2008 - Z. Pančíková: K problematike spoločenského postavenia metalurgov v dobe bronzovej. Hroby metalurgov z územia Čiech, Moravy a Slovenska. In: Z. Měřínský/J. Klápště (ed.): Moravskoslezská škola doktorských studiú. Seminář 1 . Dissertationes archaeologicae Brunenses/Pragensesque I. Brno 2008, 69-83.

Paulík 1962 - J. Paulík: Mazanica s plastickou výzdobou v dobe bronzovej na Slovensku. Študijné zvesti AÚ SAV 10, 1962, 27-57.

Pástor 1955 - J. Pástor: Popolnicové pohrebište v Haniske pri Košiciach. Archeologické rozhledy 7, 1955, 737-746.
Petres/Bándi 1969 - É. F. Petres/ G. Bándi: Ásatás Lovasberény - Mihályváron. Archaeologiai Értesítő 96, 1969, 170-177.

Pernicka 1998 - E. Pernicka: Die Ausbreitung der Zinnbronze im 3. Jahrtausend. In: B. Hänsel (Hrsg.): Mensch und Umwelt in der Bronzezeit Europas - Man and Environment in Bronze Age Europe. Kiel 1998, 135-147.

Přichystal 2009 - A. Přichystal: Kamenné suroviny v pravěku východní části střední Evropy. Brno 2009.

Přichystal/Škrdla 2014 - A. Přichystal/P. Škrdla: Kde ležel hlavní zdroj obsidiánu v pravěku střední Evropy? Slovenská archeológia 62, 2014, 215-226.

Říhovský 1989 - J. Říhovský: Die Sicheln in Mähren. Prähistorische Bronzefunde XVIII/3. München 1989.

Sofaer 2010 - J. Sofaer: Technology and Craft. In: T. Earle/ K. Kristiansen (eds.): Organizing Bronze Age Societies. The Mediterranean, Central Europe, and Scandinavia Compared. Cambridge 2010, 185-217.

Soják 2003 - M. Soják 2003: Sídlisko z doby bronzovej v Poprade-Matejovciach. In: J. Gancarski (red.): Epoka brazu i wczesna epoka żelaza w Karpatach polskich. Krosno 2003, 449-476.

Stejskalová 1999 - D. Stejskalová: Možná cesta drobného šperku z Blízkeho Východu do střední Evropy. Archeologie ve středních Čechách 3, 1999, 87-92.

Szabová 2017 - L. Szabová: Analýza materiálu z objektu č. 519 v kontexte sídliska Nižná Myšla-Várhegy, vzhl’adom na prínos pre poznanie metalurgie doby bronzovej. Bakalárska práca. Univerzita Komenského v Bratislave. Filozofická fakulta. Katedra archeológie. Bratislava 2017. Dostupné na: https://opac.crzp.sk/?fn=detailBiblioForm \& sid=F065241B7212E93A20116E33722A \& seo=CRZP-detail-kniha

Szabová 2019 - L. Szabová: Interpretácie SV časti lokality Várhegy II v Nižnej Myšli. Diplomová práca. Univerzita Komenského v Bratislave. Filozofická fakulta. Katedra archeológie. Bratislava 2019. Dostupné na: https://opac. crzp.sk/?fn=detailBiblioForm\&sid=E90F038DF6A63573 E4BE9D5D0CE5\&seo=CRZP-detail-kniha

Szabó 1996 - G. Szabó: Az urnamezős kultúra fémművessége a régészeti kísérletek tükrében. Pápai Múzeumi Értesító 6, 1996, 265-276.

Šimčík 2017 - P. Šimčík: Plasticky zdobená mazanica z Prešova-Nižnej Šebastovej. Zborník SNM 111. Archeológia 27, 2017, 89-96.

Tolksdorf a i. 2019 - J. F. Tolksdorf/F. Schröder/L. Petr/ C. Herbig/K. Kaiser/P. Kočár/A. Fülling/S. Heinrich/ H. Hönig/Ch. Hemker 2019: Evidence for Bronze Age and Medieval tin placer mining in the Erzgebirge mountains, Saxony (Germany). Geoarchaeology 2019, 1-19. DOI: https://doi.org/10.1002/gea.21763

Tzachili 2008 - I. Tzachili: Aegean Metallurgy in the Bronze Age: Recent Developments. In: I. Tzachili (ed.): Aegean Metallurgy in the Bronze Age. Athens 2008, 7-33.

Valde-Nowak/Gancarski 1999 - P. Valde-Nowak/J. Gancarski: Bronzezeitliche Spaltindustrie der Pleszów- und der Otomani-Füzesabony-Kultur aus den Siedlungen Trzcinica und Jasło. Ein Überblick. In: J. Gancarski (red.): Kultura Otomani-Füzesabony - rozwój, chronologia, gospodarka - Die Otomani-Füzesabony-Kultur - Entwicklung, Chronologie, Wirtschaft. Krosno 1999, 181-200.

Vavák a i. 2015 - J. Vavák/P. Jelínek/J. Hlavatá/L. Illášová: Doklady metalurgie na opevnenom sídlisku mad’arovskej kultúry v Budmericiach. In: J. Bátora/P. Tóth (ed.): Ked'bronz vystriedal med'. Zborník príspevkov z XXIII. me- 
dzinárodného sympózia "Staršia doba bronzová v Čechách, na Morave a na Slovensku“, Levice 8.-11. októbra 2013. Archaeologica Slovaca Monographiae. Communicationes 18. Bratislava - Nitra 2015, 157-186.

Vicze 2011 - M. Vicze: Bronze Age Cemetery at Dunaújuáros-Duna-düló. Budapest 2011.

Rukopis prijatý 12. 11. 2021

Summary translated by V. Tejbusová

PhDr. Ladislav Olexa

Archeologický ústav SAV

Hrnčiarska 13

SK - 04001 Košice

olexal@saske.sk

Mgr. Lucia Szabová

lucia.szabova7@gmail.com
Vladár 1973 - J. Vladár: Osteuropäische und mediterrane Einflüsse im Gebiet der Slowakei während der Bronzezeit. Slovenská archeológia 21, 1973, 253-357.

Zápotocký/Zápotocká 2008 - M. Zápotocký/M. Zápotocká: Kutná Hora-Denemark. Hradiště řivnáčské kultury (ca 3000-2800 př. Kr.). Praha 2008.

Mgr. Štefan Olšav

Archeologický ústav SAV

Hrnčiarska 13

SK - 04001 Košice

stefan.olsav@saske.sk

\title{
Selected Evidence of Crafts at the Fortified Settlement II in Nižná Myšla
}

\author{
Ladislav Olexa - Štafan Olšav - Lucia Szabová
}

\author{
SUMMARY
}

Nižná Myšla is located in Eastern Slovakia, in Košiceokolie district. From the east, it borders with the Slanské vrchy hills, while the river Hornád surrounds the area in the west. Its tributary rivers - the Olšava and Torysa join the river Hornád near the village. The site itself - an Early Bronze Age burial ground and a fortified settlement (I and II) from the Early and Middle Bronze Age - is situated on the promontory near the southern boarded of the cadastral area with the village of Vyšná Myšla, which is now separated by the Olšava river. The strategical location of the settlement in the landscape was a good condition for its development, which was expressed also in other nearby settlements in several prehistorical and historical periods, but mostly in the Early and Middle Bronze Age at the site of Várhegy. Fortified settlement II from the beginning of the Middle Bronze Age was a centre of production, economy, religion and later also of power. With regard to the extent of the topic, the article focuses only on activities associated with metallurgy and lithic industry. Production activities were an inseparable part of everyday life of people, which was reflected also in the number of tools discovered at the site. Lithic industry in this period was still direct or indirect part of almost all crafts. Its representation at the fortified settlement is, thus, rather numerous. Most of the chipped industry was found in the north-east part of the settlement, where production took place in two houses near a metallurgical feature (feature 519). It cannot be excluded that together with metallurgy, activities associated with chipped industry were carried out in the feature. Nevertheless, it seems more probable that after the feature had lost its primary function, it was used as a refuse pit by people from the production district in its nearest vicinity. The high occurrence of chipped lithic industry was also found on the eastern periphery of the fortified settlement, in a residential feature near the gate. Here, a nearby feature with an originally different function was used as well. Near the house and the gate, a protective ditch was located, used as a refuse pit. Fewer exemplars of chipped industry were discovered in other parts of the fortified settlement, which documents its common use at 
the site as well as its domestic production. As for other lithic industry, similar patterns repeat for individual types of tools. The north-east part of the fortified settlement is the most used area with activities associated with other lithic industry. Smaller concentrations of lithic industry were found mainly further to the south, in the context of houses and features in their immediate surroundings, which suggests domestic production. In general, finds of other lithic industry were sporadically found all over the studied area of the fortified settlement. Despite this fact, it is obvious that crafts were carried out in houses and their immediate surroundings, which allows a certain idea of domestic production of lithic industry and its use in households. The north-east part of the fortified settlement is an exception. There, a high concentration of chipped and other lithic industry suggests existence of a craft area. In this area, the highest concentration of finds of a specialized craft - metal founding - was located. In this case, we must point to feature 519 , which is considered a foundry. The archaeological research has also pointed to possible activities associated with metallurgy also in the wider surroundings of this feature, still located in the north-east part of fortified settlement II. Apart from this space, casting moulds were sporadically found in features scattered over the settlement's area. Metallurgical feature 519 was kidney-shaped, with dimensions of $4.5 \times 6 \mathrm{~m}$. Stone casting moulds, casting crucible with remains of bronze and bronze clusters were found there. Besides movable finds, quadruple estrich screed with a kiln's front pit was

Fig. 1. Share of stone raw materials used for making chipped lithic industry at fortified settlement II in Nižná Myšla. 1 - obsidian; 2 - limnosilicite; 3 - limnosilicite (Banské type); 4 - chert (Ondavský type); 5 - radiolarite; 6 - silicite from Kraków-Częstochowa Upland, the Gojść Variety; 7 - silicite from Kraków-Częstochowa Upland; 8 - silicite; 9 - quartz, 10 - chert; 11 - erratic silicites from glacial sediments; 12 - silicified siltstone; 13 - opal; 14 - unidentified.

Fig. 2. Share of types of chipped lithic tools at fortified settlement II in Nižná Myšla. 1 - curved silicite knife; 2 - sickle-blades; 3 - saws; 4 - endscrapers and microendscrapers; 5 - drills; 6 - notching tool; 7 - graver; 8 - arrowheads.

Fig. 3. Nižná Myšla-Várhegy. Inventary of the grave no. 133. 1 - chipped industry; 2,3 - boar tusks; 4 - spiral tube; 5 - two-piece tuff mould. Scale: a - 1, 4; b-2, 3, 5 (Olexal Nováček 2013, pl. 63: 133).

Fig. 4. Nižná Myšla-Várhegy. Grave no. 280. 1 - vessel with two handles; 2 - amphora; 3 - jug; 4 - two-part mould; 5 - obsidian blade; 6 - bone awl; 7 - bone awl; 8 - bronze needle; 9 - antler; 10 - wild boar tusk appliqués; 11 - wild boar tusk pendants; 12 - shells, bronze spirals and bronze tubes; 13 - bronze pin with spherical head; 14 - bronze bracelet; 15 - clay nozzle; 16 - stone hammer.

Fig. 5. Nižná Myšla-Várhegy. Object 519 - metallurgical workshop. a - pit with ash filling; b - post-hole; c - unexplored area; d - grave; e - pyrotechnological device; f - pit (adjusted according Szabová 2017, fig. 1).

Fig. 6. Nižná Myšl'a-Várhegy. Pyrotechnologic features from object no. 519. 1 - furnace renewed multiple times situated in the feature. North of it, there was another pyrotechnologic device. High concentration of lithic industry used for grinding, smoothing and polishing might point to activities associated with final finish of metal products. After the primary function of the feature had ended, it was secondarily used as a refuse pit. It is clear that the north-east part of fortified settlement II was - besides other functions - a craft area where production activities were concentrated, while craft activities were also common in houses and their immediate surroundings as part of domestic production. Inside the settlement, traces of crafts are rather rare, despite the number of studied settlement pits. Based on the comparison of the spatial distribution of artifacts associated with crafts from the same period and cultural environment in Nižná Myšla and in Spišský Štvrtok (Oravkinová 2018), we can see remarkable similarities, which suggests similar economic production models at both fortified settlements. For a complete evaluation and elaboration of economic production models of fortified settlements from the Otomani-Füzesabony cultural complex (OFCC), it is also necessary to evaluate other finds associated with craft activities (pottery, bone and antler production, etc.) in Nižná Myšla as well as complete processing of such finds from other fortified settlements in the cultural environment of OFCC. The results presented in this article follow from the previously studied approx. one third of the supposed area of fortified settlement II. Further systematic research will definitely complement and specify the presented conclusions.

with four screeds placed one above the other, divided by layers of burned clay and bronze ingots discovered in object no. 519;2 - destruction of the furnace bounded with massive stones. $\mathrm{a}$ - pit with ash filling; $\mathrm{b}$ - post-hole; c-stone; d - burnt layer; e - estrich.

Fig. 7. Nižná Myšla-Várhegy. 1 - fireplace bounded with stones; 2 - clay nozzle discovered right next to the fireplace.

Fig. 8. Nižná Myšla-Várhegy. Daub from the settlement pits. A - fragments of plastically shaped daub, that were part of architectonical or decorative element; B - daub with holes after wattle imprints.

Fig. 9. Nižná Myšla-Várhegy. 1 - destruction of furnace in object no. 577; 2 - outline of the layer with the destruction of furnace in object no. 577. a - mixed ash and brown clay; $b$ - small stones mixed with clay in a layer under estrich; c - estrich - the bottom of the furnace; $\mathrm{d}$ - stone; e - burnt clay; $\mathrm{f}$ - shard; $\mathrm{g}$ - tuff; $\mathrm{h}$ - animal bone (rib); $\mathrm{i}$ - animal bone; $\mathrm{j}$ - shard.

Fig. 10. Nižná Myšla-Várhegy. Sample of the metal artefacts from the north-eastern part of the fortified settlement II.

Fig. 11. Nižná Myšla-Várhegy. Silicite curved knife (Krummesser) from disturbed context at fortified settlement II.

Fig. 12. Nižná Myšla-Várhegy. Potential projectiles for slingshot made from tufa stone, discovered in the ditch of fortified settlement II (after Gašaj 2020, 75).

Plan 1. Nižná Myšla-Várhegy. Excavated areas of fortified settlements I and II, schematic plan of the site (Nováček 2017, map 2). a - fortified settlement I; b - graveyard of fortified settlement I; c - fortified settlement II. 
Plan 2. Nižná Myšla-Várhegy. Spatial distribution of chipped lithic industry - cores.

Plan 3. Nižná Myšla-Várhegy. Spatial distribution of chipped lithic industry - complete collection.

Plan 4. Nižná Myšla-Várhegy. Spatial distribution of other lithic industry.

Plan 5. Nižná Myšla-Várhegy. Spatial distribution of stone axes and hammer-axes.

Plan 6. Nižná Myšla-Várhegy. Spatial distribution of stone tools for drilling, smoothing and polishing.

Plan 7. Nižná Myšla-Várhegy. Spatial distribution of crushers.

Plan 8. Nižná Myšla-Várhegy. Spatial distribution of stone moulds.

Plan 9. Nižná Myšla-Várhegy. Spatial distribution of stone curved knives.

Tab. 1. Nižná Myšla-Várhegy, object no. 519. Results of spectral analysis from surface of clay melting-pot with traces of smelting non-ferrous metals. Analysis made by Zuzana Felcanová.

Tab. 2. Nižná Myšla-Várhegy, object no. 519. Results of spectral analysis of bronze ingot. Analysis made by Zuzana Felcanová.
Pl. I. Nižná Myšla-Várhegy. Clay melting-pots and their fragments from object no. 519.

Pl. II. Nižná Myšla-Várhegy. 1-8, 10-18 - selection of the casting mould from the fortified settlement II; 9 - item made of tufa stone (game desk/ritual object), previously interpreted as casting mould.

Pl. III. Nižná Myšla-Várhegy. Sample of metal artifacts from object no. 519.

Pl. IV. Nižná Myšl’a-Várhegy. 1-7 - stone cores; 8-15 stone arrowheads; 16, 17 - semi-finished products for arrowheads making.

Pl. V. Nižná Myšla-Várhegy. 1-8 - fragments of stone hammer-axes; 9, 11-14 - stone axes and their fragments; 10 - stone chisel.

Pl. VI. Nižná Myšla-Várhegy. 1, 9, 13, 14 - stone objects with unknown function; 2 - fragment of miniature hammeraxe made of tufa stone; 4,6 - stone discs; 5 - antler disc; $3,7,8$ - perforated round objects made of tufa stone; 10-12 - stone pendants; 15 - shoe-adze; 16-19 - crushers. Scale: $a-1-12 ; b-13-19$.

Pl. VII. Nižná Myšlla-Várhegy. 1-11 - grindstones; 12, 13 passive tools for grinding.

Pl. VIII. Nižná Myšla-Várhegy. Curved stone knives from fortified settlement II. 
